Prepared in cooperation with the Three Affiliated Tribes

\title{
Characterization of Surface-Water and Groundwater Quality on the Fort Berthold Reservation, North Dakota, 2014-17
}

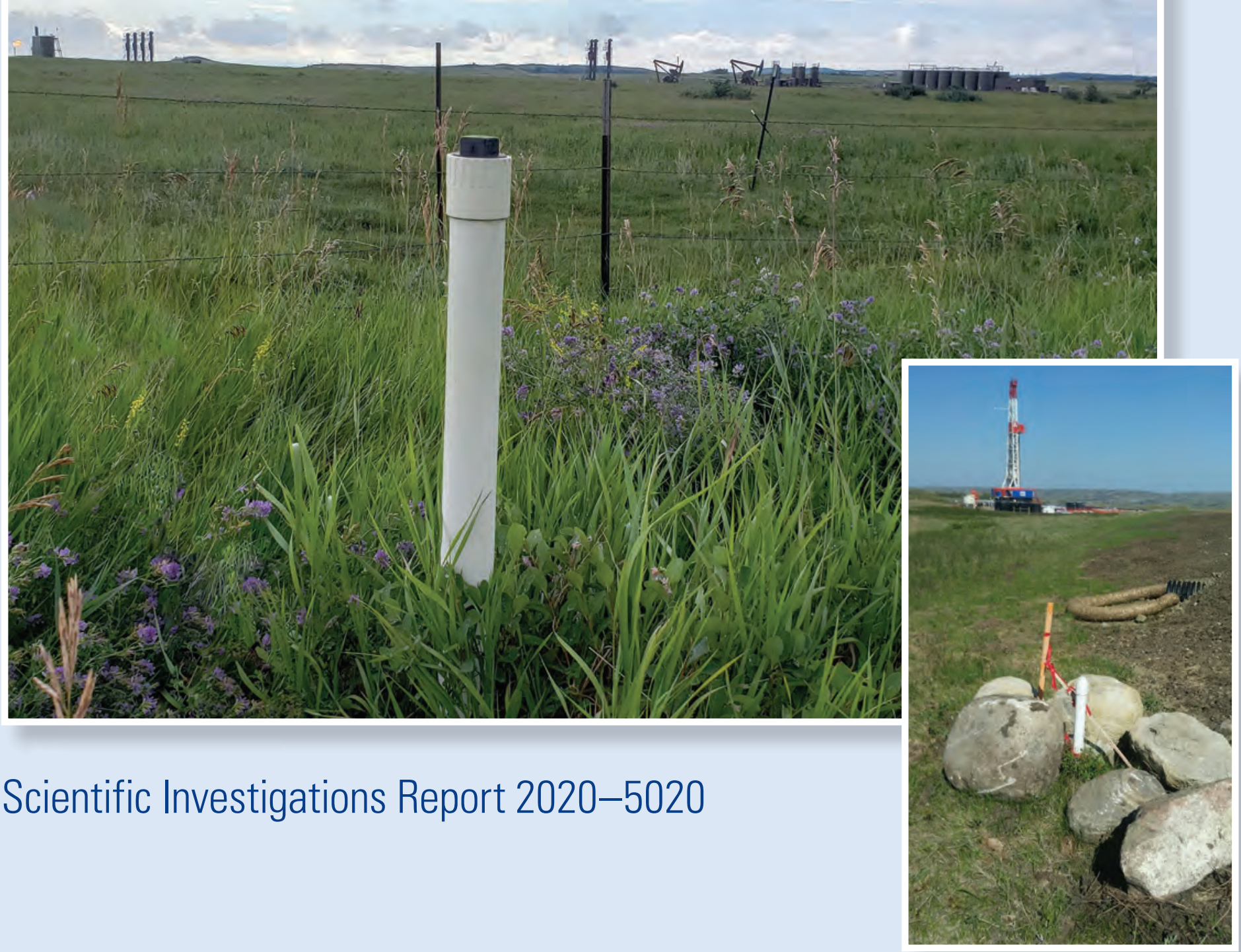


Cover. Aerial extent of agricultural pasture and oil production activity on the Fort Berthold Reservation, south of Mandaree, North Dakota, July 18, 2019 (upper left). Monitoring well site near an active oil production well on the Fort Berthold Reservation, Mandaree, North Dakota, August 16, 2016 (lower right). Photographs by Robert Lundgren, U.S. Geological Survey. 


\section{Characterization of Surface-Water and Groundwater Quality on the Fort Berthold Reservation, North Dakota, 2014-17}

By Robert F. Lundgren and Mary J. Iorio

Prepared in cooperation with the Three Affiliated Tribes

Scientific Investigations Report 2020-5020 


\title{
U.S. Department of the Interior \\ DAVID BERNHARDT, Secretary
}

\author{
U.S. Geological Survey \\ James F. Reilly II, Director
}

U.S. Geological Survey, Reston, Virginia: 2020

For more information on the USGS - the Federal source for science about the Earth, its natural and living resources, natural hazards, and the environment—visit https://www.usgs.gov or call 1-888-ASK-USGS.

For an overview of USGS information products, including maps, imagery, and publications, visit https://store.usgs.gov/.

Any use of trade, firm, or product names is for descriptive purposes only and does not imply endorsement by the U.S. Government.

Although this information product, for the most part, is in the public domain, it also may contain copyrighted materials as noted in the text. Permission to reproduce copyrighted items must be secured from the copyright owner.

Suggested citation:

Lundgren, R.F., and lorio, M.J., 2020, Characterization of surface-water and groundwater quality on the Fort Berthold Reservation, North Dakota, 2014-17: U.S. Geological Survey Scientific Investigations Report 2020-5020, 37 p., https://doi.org/10.3133/sir20205020.

ISSN 2328-0328 (online) 


\section{Acknowledgments}

The authors thank Tricia Pfeiffer (U.S. Environmental Protection Agency Region 8, Denver, Colorado), who has been involved with the project from the initial phases through the final data review and release. Tricia served admirably as the Three Affiliated Tribes water-quality lead and provided outstanding coordination among the laboratories and management personnel of the Three Affiliated Tribes, U.S. Geological Survey, and U.S. Environmental Protection Agency. The authors also gratefully acknowledge the landowners who granted access to their property for the acquisition of data.

The authors thank Anthony Ranalli (U.S. Geological Survey Hydrologist, Colorado Water Science Center, retired) who was instrumental in the development of this project while serving as the Tribal Liaison between the U.S. Geological Survey and U.S. Environmental Protection Agency and Joel Galloway (U.S. Geological Survey Supervisory Hydrologist, Dakota Water Science Center) for project technical guidance and coordination. 



\section{Contents}

Acknowledgments ……...................................................................................................................

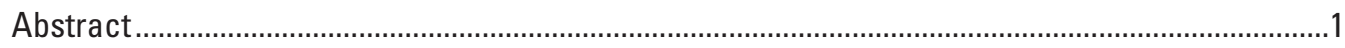

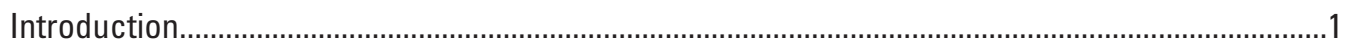

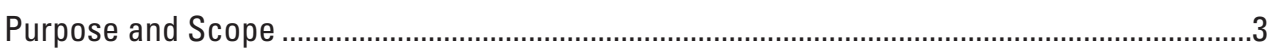

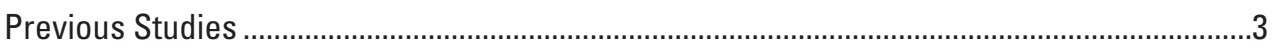

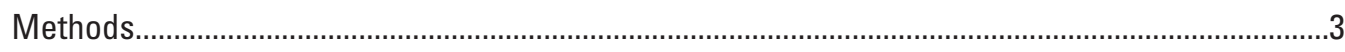

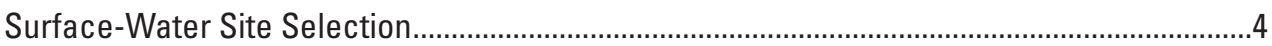

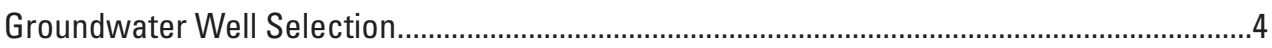

Data Collection and Laboratory Analysis Methods ................................................................4

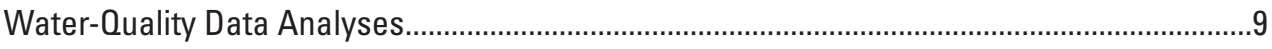

Characterization of Water Quality on the Fort Berthold Reservation ..............................................14

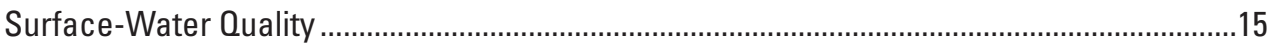

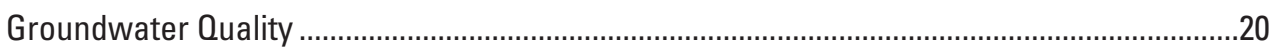

Summary

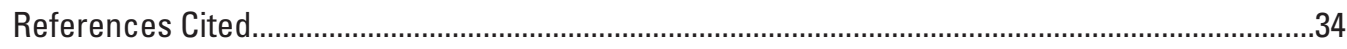

Appendix 1 Quality-Assurance Data and Summary Statistics for Water-Quality Constituents in Surface Water and Groundwater ................................................................36

Appendix 2 Summary Statistics for Historical Water-Quality Constituents in Major Aquifers on Fort Berthold Reservation, North Dakota ........................................................37

\section{Figures}

1. Map showing sampling locations at U.S. Geological Survey streamgaging stations and groundwater wells on the Fort Berthold Reservation during 2014-17..........2

2. Graph showing daily mean streamflow and water-quality samples collected at streamgaging station Bear Den Creek near Mandaree, North Dakota (U.S. Geological Survey station number 06332515), 2014-17

3. Maps showing spatial distribution of dissolved chloride concentrations, in milligrams per liter, for groundwater wells on Fort Berthold Reservation, North Dakota, 2014-17

4. Maps showing spatial distribution of dissolved solids concentrations, in milligrams per liter, for groundwater wells on Fort Berthold Reservation, North Dakota, 2014-17

5. Maps showing spatial distribution of dissolved sodium concentrations, in milligrams per liter, for groundwater wells on Fort Berthold Reservation, North Dakota, 2014-17

6. Maps showing spatial distribution of dissolved sulfate concentrations, in milligrams per liter, for groundwater wells on Fort Berthold Reservation, North Dakota, 2014-17

7. Maps showing spatial distribution of dissolved arsenic concentrations, in micrograms per liter, for groundwater wells on Fort Berthold Reservation, North Dakota, 2014-17

8. Maps showing spatial distribution of dissolved iron concentrations, in micrograms per liter, for groundwater wells on Fort Berthold Reservation, North Dakota, 2014-17 
9. Maps showing spatial distribution of dissolved manganese concentrations, in micrograms per liter, for groundwater wells on Fort Berthold Reservation, North Dakota, 2014-17.

10. Maps showing spatial distribution of dissolved ammonia concentrations, in milligrams per liter, for groundwater wells on Fort Berthold Reservation, North Dakota, 2014-17

\section{Tables}

1. Period of record for available surface-water data from U.S. Geological Survey streamgaging stations on the Fort Berthold Reservation, North Dakota

2. Site information for groundwater wells sampled on Fort Berthold Reservation, North Dakota, 2014-17

3. List of field measurements and constituents analyzed from samples collected on the Fort Berthold Reservation, North Dakota, 2014-17.

4. Laboratory reporting levels for selected water-quality constituents in surface water and groundwater on Fort Berthold Reservation, North Dakota, 2014-17

5. Drinking water-quality standards and health-based screening levels available for water-quality constituents analyzed on Fort Berthold Reservation, North Dakota, 2014-17

6. Summary statistics for historical streamflow measurements at surface-water sites on Fort Berthold Reservation, North Dakota, October 1973 to April 2014

7. Summary statistics for selected water-quality constituents at surface-water sites on Fort Berthold Reservation, North Dakota, 2014-17

8. Summary statistics for selected water-quality constituents in groundwater wells on Fort Berthold Reservation, North Dakota, 2014-17

\section{Conversion Factors}

U.S. customary units to International System of Units

\begin{tabular}{lcl}
\hline \multicolumn{1}{c}{ Multiply } & \multicolumn{1}{c}{ By } & \multicolumn{1}{c}{ To obtain } \\
\hline inch (in.) & Length & \\
inch (in.) & 2.54 & centimeter $(\mathrm{cm})$ \\
foot (ft) & 25.4 & millimeter $(\mathrm{mm})$ \\
mile (mi) & 0.3048 & meter $(\mathrm{m})$ \\
yard (yd) & 1.609 & kilometer $(\mathrm{km})$ \\
\hline & 0.9144 & meter $(\mathrm{m})$ \\
\hline acre & Area & \\
\hline square mile (mi $\left.{ }^{2}\right)$ & 4,047 & square meter $\left(\mathrm{m}^{2}\right)$ \\
\hline & 2.590 & square kilometer $\left(\mathrm{km}{ }^{2}\right)$ \\
\hline foot per second (ft/s) & Flow rate & meter per second $(\mathrm{m} / \mathrm{s})$ \\
cubic foot per second $(\mathrm{ft} 3 / \mathrm{s})$ & 0.3048 & cubic meter per second $\left(\mathrm{m}^{3} / \mathrm{s}\right)$ \\
\hline
\end{tabular}

Temperature in degrees Fahrenheit $\left({ }^{\circ} \mathrm{F}\right)$ may be converted to degrees Celsius $\left({ }^{\circ} \mathrm{C}\right)$ as follows: ${ }^{\circ} \mathrm{C}=\left({ }^{\circ} \mathrm{F}-32\right) / 1.8$. 


\section{Datum}

Vertical coordinate information is referenced to the North American Vertical Datum of 1988 (NAVD 88).

Horizontal coordinate information is referenced to the North American Datum of 1983 (NAD 83).

\section{Supplemental Information}

Specific conductance is given in microsiemens per centimeter at 25 degrees Celsius $\left(\mu \mathrm{S} / \mathrm{cm}\right.$ at $\left.25^{\circ} \mathrm{C}\right)$.

Concentrations of chemical constituents in water are given in either milligrams per liter (mg/L) or micrograms per liter $(\mu \mathrm{g} / \mathrm{L})$.

\section{Abbreviations}

EWI equal-width-increments

MCL maximum contaminant level

NWIS National Water Information System

SDWR secondary drinking water regulation

TAT Three Affiliated Tribes

EPA U.S. Environmental Protection Agency

USGS U.S. Geological Survey 



\title{
Characterization of Surface-Water and Groundwater Quality on the Fort Berthold Reservation, North Dakota, 2014-17
}

\author{
By Robert F. Lundgren'1 and Mary J. Iorio ${ }^{2}$
}

\section{Abstract}

The Fort Berthold Reservation is in west-central North Dakota and home to the Three Affiliated Tribes. The primary water-resources concerns on the Fort Berthold Reservation are associated with the different types of land uses from agricultural activities and the rapid development of oil and gas resources in western North Dakota. The Three Affiliated Tribes Environmental Department identified the need for long-term water-quality monitoring throughout the Fort Berthold Reservation to better understand the potential effects on surface-water and groundwater quality and to determine if water quality is changing with time. The U.S. Geological Survey, in cooperation with the Three Affiliated Tribes, identified surface-water sites and groundwater wells that represent the water resources in major drainages and the most utilized aquifers on the reservation. A water-quality monitoring program was designed to address data gaps and provide consistent long-term data that can be used to identify potential effects on water quality. During 2014-17, the initial water-quality sampling efforts associated with this program were completed. The efforts provide a current (2019) characterization of water-quality conditions in surface water and groundwater and can assist in establishing a long-term water-quality monitoring program.

\section{Introduction}

The Fort Berthold Reservation is a reservation in westcentral North Dakota that is home for the federally recognized Mandan, Hidatsa, and Arikara Nation, also known as the Three Affiliated Tribes (TAT; fig. 1). The Fort Berthold Reservation (hereafter referred to as "reservation") is on Lake Sakakawea in parts of Dunn, McKenzie, McLean, Mercer, Mountrail, and Ward Counties (fig. 1) and includes an area of about 1,530 square miles or 980,000 acres (Mandan, Hidatsa, and

\footnotetext{
1U.S. Geological Survey.
}

${ }^{2}$ Three Affiliated Tribes.
Arikara Nation, 2020). The lake is a critical tribal resource because it supplies drinking water to tribal members and provides recreational opportunities. Land use on the east side of the reservation is predominantly cropland and on the west side of the reservation is predominantly rangeland used for the cattle grazing. Agricultural land use on the reservation has the potential to introduce fertilizers, pesticides, and livestock waste into streams, groundwater, and Lake Sakakawea.

In addition to the potential effects of agricultural activities, the rapid development of oil and gas resources in western North Dakota combined with the corresponding transport of extracted products from that energy development also have increased the potential to adversely affect water resources on the reservation. The development of these resources requires the transportation of oil and produced water (a by-product of oil production) from oil fields to refineries, transport terminals, or disposal locations. Transportation is typically done via pipeline, rail, or truck. Although the density of energy development continues to increase outside the reservation boundaries (North Dakota Industrial Commission, 2017), the potential for catastrophic environmental and economic effects from spills and other anthropogenic activities is ever present, especially for the hydrologic processes within the reservation.

During 2017, 704 contained or uncontained spills in Dunn, McKenzie, Mountrail, and Mercer Counties were reported to the North Dakota Department of Environmental Quality (2018). In 2014, one of the largest spills in State history took place on the reservation near Mandaree, N. Dak. (fig. 1). A leaky pipeline spilled an estimated 1 million gallons of produced water that reached Bear Den Bay of Lake Sakakawea (Dalrymple, 2018b). In addition, about 3 million gallons of produced water were reported to have leaked from a pipeline in January of 2015, spilling into Blacktail Creek (not shown on map) above the confluence with the Missouri River upstream outside of the reservation. The spills to the environment are not always accidental. In January 2018, a trucking company paid a fine of $\$ 950,000$ to the North Dakota Industrial Commission for illegally dumping produced water on a Williams County gravel road (Dalrymple, 2018a).

A primary goal of the TAT Environmental Department is to protect water quality. The different types of land use on the reservation have the potential to affect water quality of streams 


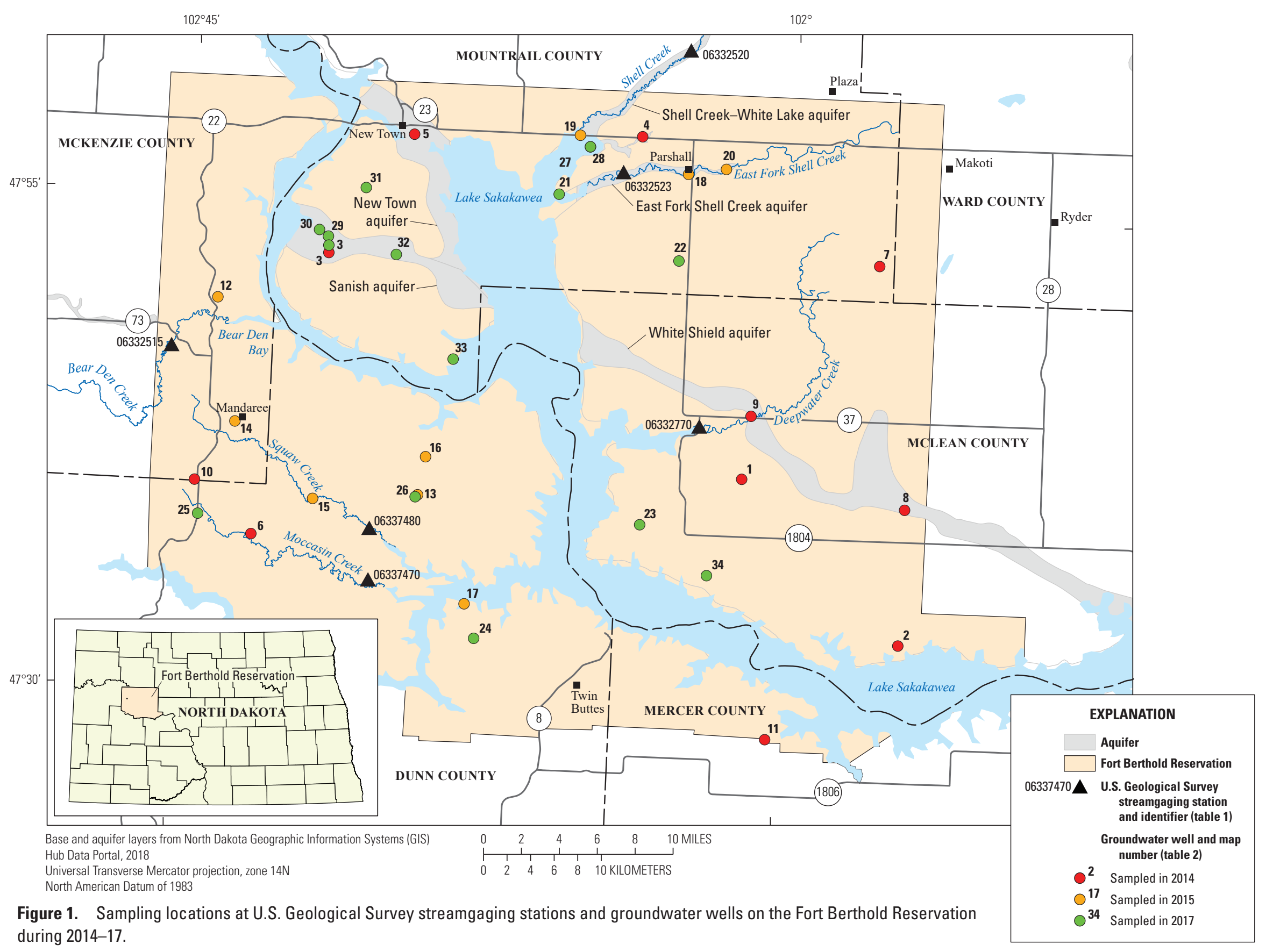


and groundwater on the reservation and potentially affect Lake Sakakawea farther downstream. As a result of these water-resources concerns, the TAT Environmental Department identified the need for long-term water-quality monitoring of streams and groundwater throughout the reservation to better understand the potential effects of land use on surface-water and groundwater quality and to determine if water quality is changing with time. Therefore, a water-quality monitoring program was designed to address data gaps and provide consistent long-term data that can be used to identify potential effects on water quality. The U.S. Geological Survey (USGS), in cooperation with the Three Affiliated Tribes, identified surface-water sites and groundwater wells that represent the water resources in major drainages and the most utilized aquifers on the reservation. During 2014-17, the initial waterquality sampling efforts associated with this program were completed. The efforts provide a current (2019) characterization of water-quality conditions and can assist in establishing a long-term water-quality monitoring program.

\section{Purpose and Scope}

The purpose of this report is to provide a current (2019) characterization of surface-water and groundwater-quality data collected on the reservation during 2014-17. This report describes the study design, sampling methods, and statistical summaries of the water-quality data for a broad suite of inorganic and organic chemical constituents. Six surface-water sites on streams and 34 groundwater wells were sampled for 232 constituents that include major ions, nutrients, trace elements, and organic compounds. Of the 232 constituents, 11 were selected for more detailed analyses and discussion based on their common association with agricultural and energy development land uses. These dissolved constituents are chloride, dissolved solids, sodium, sulfate, aluminum, arsenic, iron, manganese, ammonia, nitrate, and nitrite. The surface-water sites were sampled primarily during April, June, August, and October. The groundwater wells were primarily sampled once.

\section{Previous Studies}

Several previous studies were completed that described the water resources of the reservation. A study was done by Dingman and others (1954) that located adequate water supplies and sources of sand and gravel on the uplands of the reservation. The effects of land-use activity on the water quality of five drainage basins on and adjacent to the reservation were described in Macek-Rowland and Lent (1996). The five ephemeral streams in these basins were East Fork Shell Creek, Deepwater Creek, Bear Den Creek, Moccasin Creek, and Squaw Creek. The study documented variations in agricultural land-use patterns and spatial and temporal variability of selected nutrients, total organic carbon, selected pesticides, and selected bacteria concentrations in the five streams (Macek-Rowland and Lent, 1996). The land-use data also were compared to water-quality data to determine relations between agricultural land-use practices and surface-water quality on the reservation. Spatial and temporal variations in nonpoint-source contamination in surface water in the reservation area during 1990-93 were related to variations in land-use patterns and streamflow. Analysis of water-quality samples indicated that concentrations of nitrogen, phosphorus, and total organic carbon varied throughout the study area (MacekRowland and Lent, 1996).

The quantity, quality, and use of groundwater and surface-water resources of the reservation were characterized in a study by Cates and Macek-Rowland (1998). The study described the stratigraphy and distribution of aquifers underlying the reservation and the groundwater system that included the direction of movement, the recharge and discharge relations, the volume of groundwater in storage, the hydraulic properties of the aquifers, and the quality of groundwater. The study also documented the average streamflow, the year-toyear and seasonal variations in streamflow, and the quality of water in streams on the reservation and completed an inventory of the water use. The study data were collected between January 1990 and December 1992 and supplemented by historical data and information from previous investigations that are published in Wald and Cates (1995). No groundwaterquality monitoring on the reservation is known to have been completed since the Cates and Macek-Rowland (1998) study.

In 2013, a water-resources investigation was done by private consultants that was prepared for the TAT to provide a concise summary of the groundwater and surface-water resources, which focused primarily on quantity and availability, within the reservation (Tricia Pfeiffer, U.S. Environmental Protection Agency, written commun., 2017).

\section{Methods}

This section describes the methods used for selection of surface-water sites and groundwater wells, data collection, laboratory methods, and water-quality data analyses. In general, surface-water sites and groundwater wells were selected to represent the water resources in major drainages and the aquifers most used on the reservation. Water-quality samples collected on the reservation during 2014-17 were analyzed at the U.S. Environmental Protection Agency (EPA) Region 8 Laboratory in Golden, Colorado, and the USGS National Water Quality Laboratory in Lakewood, Colo. Water-quality data were summarized in graphical and tabular form for selected constituents with available water-quality standards related to agricultural land uses and energy development. 


\section{Surface-Water Site Selection}

Surface-water-quality samples were collected from six surface-water sites that were selected from previously established USGS streamgaging stations (table 1, fig. 1). Of the six sites selected, three are continuous-recording USGS streamgaging stations currently (2019) operated on the reservation. These three streamgaging stations are Bear Den Creek near Mandaree, N. Dak. (USGS station number 06332515), East Fork Shell Creek near Parshall, N. Dak. (USGS station number 06332523), and Deepwater Creek at mouth near Raub, N. Dak. (USGS station number 06332770). The three streamgaging stations are in drainage basins that drain into Lake Sakakawea. The Bear Den Creek streamgaging station has been continuously operated since 1966 and is west of Lake Sakakawea where rangeland is the major land use. The East Fork Shell Creek and Deepwater Creek streamgaging stations were operated from 1990 through 2013 and from 2016 to present (2019) and are northeast and east of Lake Sakakawea, respectively, where cropland is the major land use. The other three selected surface-water sites are not currently (2019) streamgaging stations, and instantaneous streamflow measurements were made concurrently with each sample collection. Streamflow data are available from the USGS National Water Information System (NWIS) database using the station numbers in table 1 (U.S Geological Survey, 2017).

\section{Groundwater Well Selection}

Reconnaissance of potential groundwater wells for sampling began in May 2014, and 34 wells were selected for sampling. Initially, groundwater wells were randomly selected using methods described by Scott (1990). The 1,530 squaremile study area of the reservation was divided into 20 equalarea cells, and 1 well in each cell was randomly selected from the population of all wells available from multiple databases using a program developed by Scott (1990). Well locations on the reservation were obtained from the USGS NWIS database (U.S Geological Survey, 2017) and North Dakota State Water Commission databases (North Dakota State Water Commission, 2014a; 2014b). The types of wells selected were used for domestic, stock (including flowing), monitoring, irrigation, and industrial water use. This randomized selection approach resulted in a network of wells that represents the most utilized aquifer units and had good spatial coverage of the area.

The selected wells were inspected for suitability for sampling; if the well could not be sampled without being affected by any type of treatment system or a pressure tank, the well was not selected for sampling because it would not represent water-quality conditions in the aquifer. Well construction information was obtained from driller's logs (North Dakota State Water Commission, 2014b) and was used to confirm the aquifer where the well was completed. Permissions were obtained from the landowner for sampling. If permissions were not granted for the selected well or if a well was deemed unsuitable for sampling, alternate wells were sought as described by Scott (1990).

Locating appropriate wells for sampling using the random selection approach (Scott, 1990) presented several challenges. The Fort Berthold Rural Water System was partially constructed and currently (2019) supplies most of the municipal water on the reservation. The rural water system pumps raw water from Lake Sakakawea, and several water treatment plants treat the water to regulatory standards and provides treated water to most residents on the reservation (Bureau of Reclamation, 2016). With the development of the Fort Berthold Rural Water System and associated decrease in groundwater use, most of the landowners' domestic wells were disconnected. In addition, many of the monitoring wells on the reservation that were drilled before the 1990s were destroyed, abandoned, or no longer existed.

Because of the challenges in locating appropriate wells using the random approach, additional wells were selected based on criteria that the well could be physically located, the well had construction information from a well driller's log, the samples could be collected without the well being affected by any type of water treatment system or a pressure tank, and the landowner had granted permission. All wells selected were completed on the reservation in the Quaternary, lower Tertiary, or Upper Cretaceous aquifer systems. The aquifers included the New Town, Sanish, Shell Creek, Tongue River, and White Shield aquifers (contained in Quaternary-age glacial and fluvial sediments); the Fort Union and Sentinel Butte aquifers (contained in the lower Tertiary-age Fort Union Formation); and the Fox Hills aquifer (contained in the Upper Cretaceous-age Fox Hills Sandstone) (North Dakota State Water Commission, 2014a).

\section{Data Collection and Laboratory Analysis Methods}

Surface-water and groundwater samples were collected by USGS and TAT personnel using methods that follow USGS protocols (U.S. Geological Survey, variously dated). The six surface-water sites were sampled twice during 2014 (May and August) and four times per year (April, June, August, and October) during 2015-17. Samples were collected from 11 groundwater wells in 2014; 9 groundwater wells in 2015; and 15 groundwater wells in 2017 (table 2, available for download at https://doi.org/10.3133/sir20205020). A well (map number 3, table 2) was sampled once in 2014 and once in 2017. This well was selected to be sampled twice because the well is in an area of dense energy development and comparisons could be made to previously collected water-quality samples.

Surface-water-quality samples were collected using the equal-width-increments (EWI) method with a depth integrated DH-81 sampler (Davis, 2005). The DH-81 sampler is constructed of a plastic bottle with plastic removable nozzles. 
Table 1. Period of record for available surface-water data from U.S. Geological Survey streamgaging stations on the Fort Berthold Reservation, North Dakota.

[Data available from U.S. Geological Survey (USGS) National Water Information System database (U.S. Geological Survey, 2017)]

\begin{tabular}{|c|c|c|c|c|c|c|}
\hline $\begin{array}{c}\text { USGS } \\
\text { station } \\
\text { number } \\
\text { (fig. 1) }\end{array}$ & USGS station name & $\begin{array}{c}\text { Latitude, } \\
\text { in decimal } \\
\text { degrees }\end{array}$ & $\begin{array}{c}\text { Longitude, } \\
\text { in decimal } \\
\text { degrees }\end{array}$ & $\begin{array}{c}\text { Elevation, } \\
\text { in feet } \\
\text { above } \\
\text { North } \\
\text { American } \\
\text { Vertical } \\
\text { Datum of } \\
1988\end{array}$ & $\begin{array}{c}\text { Drainage } \\
\text { area, in } \\
\text { square } \\
\text { miles }\end{array}$ & Streamflow period of record \\
\hline 06332515 & Bear Den Creek near Mandaree, North Dakota ${ }^{1}$ & 47.787 & -102.769 & 1,949 & 74 & 6/1966-present ${ }^{2}$ \\
\hline 06332520 & Shell Creek near Parshall, North Dakota & 48.053 & -102.137 & 1,932 & 465 & 9/1965-9/1981; 5/2014-present ${ }^{2}$ \\
\hline 06332523 & East Fork Shell Creek near Parshall, North Dakota ${ }^{1}$ & 47.949 & -102.215 & 1,890 & 360 & 7/1991-9/2013; 8/2016-present ${ }^{2}$ \\
\hline 06332770 & Deepwater Creek at mouth near Raub, North Dakota1 & 47.738 & -102.108 & 1,832 & 220 & $4 / 1990-9 / 2013 ; 8 / 2016-$ present $^{2}$ \\
\hline 06337470 & Moccasin Creek at mouth near Mandaree, North Dakota & 47.600 & -102.511 & 1,918 & 54 & 4/1990-8/1993; 5/2014-present ${ }^{2}$ \\
\hline 06337480 & Squaw Creek above mouth near Mandaree, North Dakota & 47.641 & -102.512 & 1,892 & 52 & 4/1990-8/1993; 5/2014-present ${ }^{2}$ \\
\hline
\end{tabular}

${ }^{1}$ Continuous-recording streamgaging station.

2October 2019. 
The EWI method is used to collect samples that represent the vertical and horizontal variability of the constituents in a cross section of the stream channel. The EWI method involved the collection of vertically integrated, isokinetic (velocity entering the sampler nozzle at the same velocity of the stream) samples and dividing the channel width into equal sections (generally 10). The EWI method is viable for stream velocities more than 1.5 feet per second. For samples where the stream velocities were less than 1.5 feet per second, a multiple vertical method or a weighted-bottle method was used (U.S. Geological Survey, variously dated). The multiple vertical method was collected the same as an EWI method, but the sample was not collected isokinetically. With the weighted-bottle method, a plastic device that holds the collector bottle is lowered in the stream (usually from a bridge) in multiple locations across the width of the stream. All samples, except for those collected for volatile and semivolatile organic compound analyses, were composited in a plastic churn splitter and processed onsite. Whole-water (unfiltered) samples were collected from the churn through the spigot, and filtered samples were processed through a 0.45 -micrometer capsule filter (U.S. Geological Survey, variously dated). For volatile organic compounds, a sampler was used that is specifically designed to collect nonaerated samples in $40-\mathrm{mL}$ glass septum vials. The stainless-steel volatile organic compound sampler was placed in a wadeable area of the stream until the vials were filled. The sampler was removed and drops of hydrochloric acid were added to each vial until a $\mathrm{pH}$ of less than 2 (standard units) was achieved. In addition to constituent concentrations, field measurements of water temperature, $\mathrm{pH}$, specific conductance, dissolved oxygen, turbidity, and alkalinity were made with each surface-water sample at the centroid of the stream. The field measurements were made using a multiparameter instrument that was calibrated daily prior to data collection (U.S. Geological Survey, variously dated).

Streamflow was measured at the six surface-water sites each time water-quality samples were collected using protocols described in Turnipseed and Sauer (2010). Instantaneous streamflow was determined either by direct measurement or from stage-discharge rating tables (Rantz and others, 1982), and the streamflow was used for describing the hydrologic conditions at the time of the discrete samples. All streamflow measurements and continuously recorded data are stored in the USGS NWIS database (U.S. Geological Survey, 2017).

Groundwater samples from nonmonitoring (domestic, stock, and industrial) wells were collected using the existing submersible pumps in the wells. Sampling points in the water systems were located before wells were exposed to any type of water treatment system or pressure tanks. Groundwater samples collected from wells that were flowing (artesian) used the natural pressure head of the well. Tubing was connected to the existing spigot for collection of the water samples. Groundwater samples collected from monitoring wells used a 2-inch Grundfos portable submersible pump that was lowered to about 3 feet below static water surface and above the top of the screened interval of the well.
All groundwater sample water was pumped through a closed-circuit system using Teflon tubing and connectors inside the field vehicle to ensure stable environmental control. Samples were collected within a chamber bag using clean hands/dirty hands sampling techniques (U.S. Geological Survey, variously dated). In general, samples were collected after a minimum of three casing volumes of water were purged from the wells and field measurements (water temperature, $\mathrm{pH}$, specific conductance, dissolved oxygen, and turbidity) were stable. Final readings of field measurements were recorded for the samples after stabilization. In addition to the field measurements, water levels were measured at monitoring wells before pumping and sample collection using a steel or electric tape (Cunningham and Schalk, 2011).

The groundwater- and surface-water-quality samples were analyzed at the EPA Region 8 Laboratory in Golden, Colo., and the USGS National Water Quality Laboratory in Lakewood, Colo. (table 3). Surface water and groundwater were analyzed for major ions, trace elements, nutrients, volatile and semivolatile organic compounds, gasoline and diesel range organics, dissolved and total organic carbon, and dissolved solids. The EPA Region 8 Laboratory in Golden, Colo., analyzed samples collected during 2014-15 for major ions, trace elements, nutrients, volatile and semivolatile organic compounds, gasoline and diesel range organics, dissolved and total organic carbon, and dissolved solids following procedures described in the EPA Region 8 Environmental Laboratory quality-assurance manual (Mark Burkhart, U.S. Environmental Protection Agency, written commun.; U.S. Environmental Protection Agency, 2012). For samples collected during 2016-17, the EPA Region 8 Laboratory was unable to analyze samples for nutrients, dissolved organic carbon, total organic carbon, and dissolved solids, and the USGS National Water Quality Laboratory in Lakewood, Colo., completed the analyses following procedures described in Maloney (2005) and Fishman and Friedman (1989). Dissolved solids samples collected during 2014-15 were analyzed at the EPA Region 8 Laboratory, and dissolved solids samples collected during 2016-17 were analyzed at the USGS National Water Quality Laboratory.

A total of 232 constituents were monitored in surface water and groundwater on the reservation. In this report, discussion and presentation of results focuses on 11 constituents selected based on their common association with agricultural and energy development land uses. These constituents are chloride, dissolved solids, sodium, sulfate, aluminum, arsenic, iron, manganese, ammonia, nitrate, and nitrite. Produced water from shale and tight gas formations typically contain high concentrations of some of these major ions and trace metals (U.S. Environmental Protection Agency, 2016).

Trace metals in streams exist in dissolved and particulate form. Water-quality samples were collected and analyzed for total (unfiltered) trace metals and dissolved (filtered) trace metals. The EPA Office of Water uses the dissolved fraction to set and measure compliance with water-quality standards. This approach is recommended because dissolved metals more 
Table 3. List of field measurements and constituents analyzed from samples collected on the Fort Berthold Reservation, North Dakota, 2014-17.

[Samples were analyzed at the U.S. Environmental Protection Agency Region 8 Laboratory in Golden, Colorado, and the U.S. Geological Survey National Water Quality Laboratory in Lakewood, Colorado. $\mathrm{CaCO}_{3}$, calcium carbonate; --, not applicable; $\mathrm{SO}_{4}$, sulfate; $\mathrm{N}$, nitrogen; $\mathrm{P}$, phosphorus]

\section{Field measurement or constituent}

Field measurements

\begin{tabular}{lll}
\hline Groundwater level (feet below land surface) & $\begin{array}{l}\text { Specific conductance (microsiemens per centimeter } \\
\text { at 25 degrees Celsius) } \\
\text { Dater temperature (degrees Celsius) }\end{array}$ & $\begin{array}{c}\text { Alkalinity, incremental titration } \\
\text { (milligrams per liter as } \mathrm{CaCO}_{3} \text { ) }\end{array}$ \\
$\mathrm{pH}$ (standard units) & Turbidity (formazin nephelometric unit) & Streamflow (cubic feet per second) \\
\hline Bromide & Major ions (filtered, milligrams per liter) & - Sodium \\
Calcium & Fluoride & Sulfate $\mathrm{asO}_{4}$ \\
Chloride & Magnesium & -- \\
Dissolved solids & Potassium & -- \\
\hline & Silica & \\
\hline
\end{tabular}

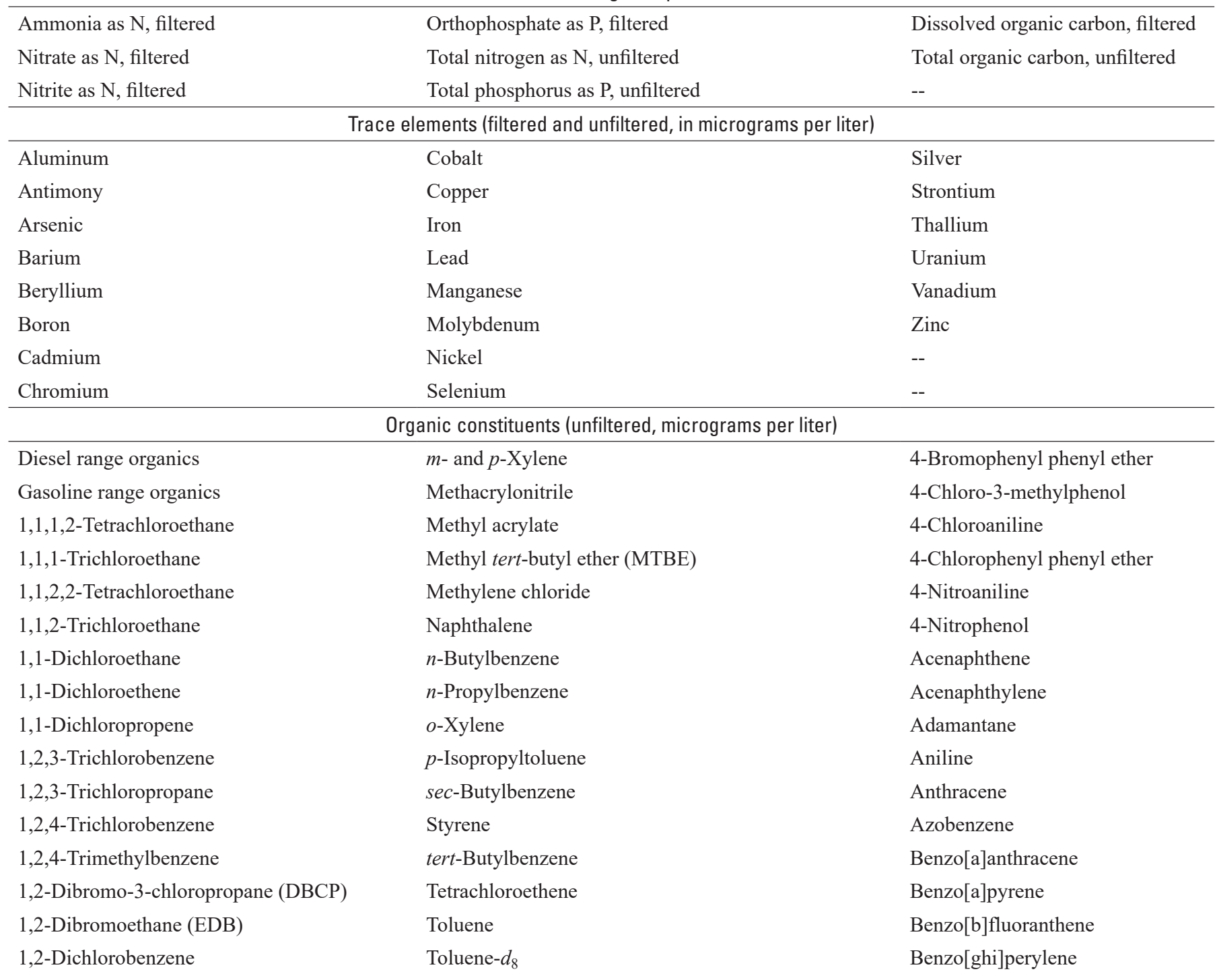


Table 3. List of field measurements and constituents analyzed from samples collected on the Fort Berthold Reservation, North Dakota, 2014-17.-Continued

[Samples were analyzed at the U.S. Environmental Protection Agency Region 8 Laboratory in Golden, Colorado, and the U.S. Geological Survey National Water Quality Laboratory in Lakewood, Colorado. $\mathrm{CaCO}_{3}$, calcium carbonate; --, not applicable; $\mathrm{SO}_{4}$, sulfate; $\mathrm{N}$, nitrogen; $\mathrm{P}$, phosphorus]

\section{Field measurement or constituent}

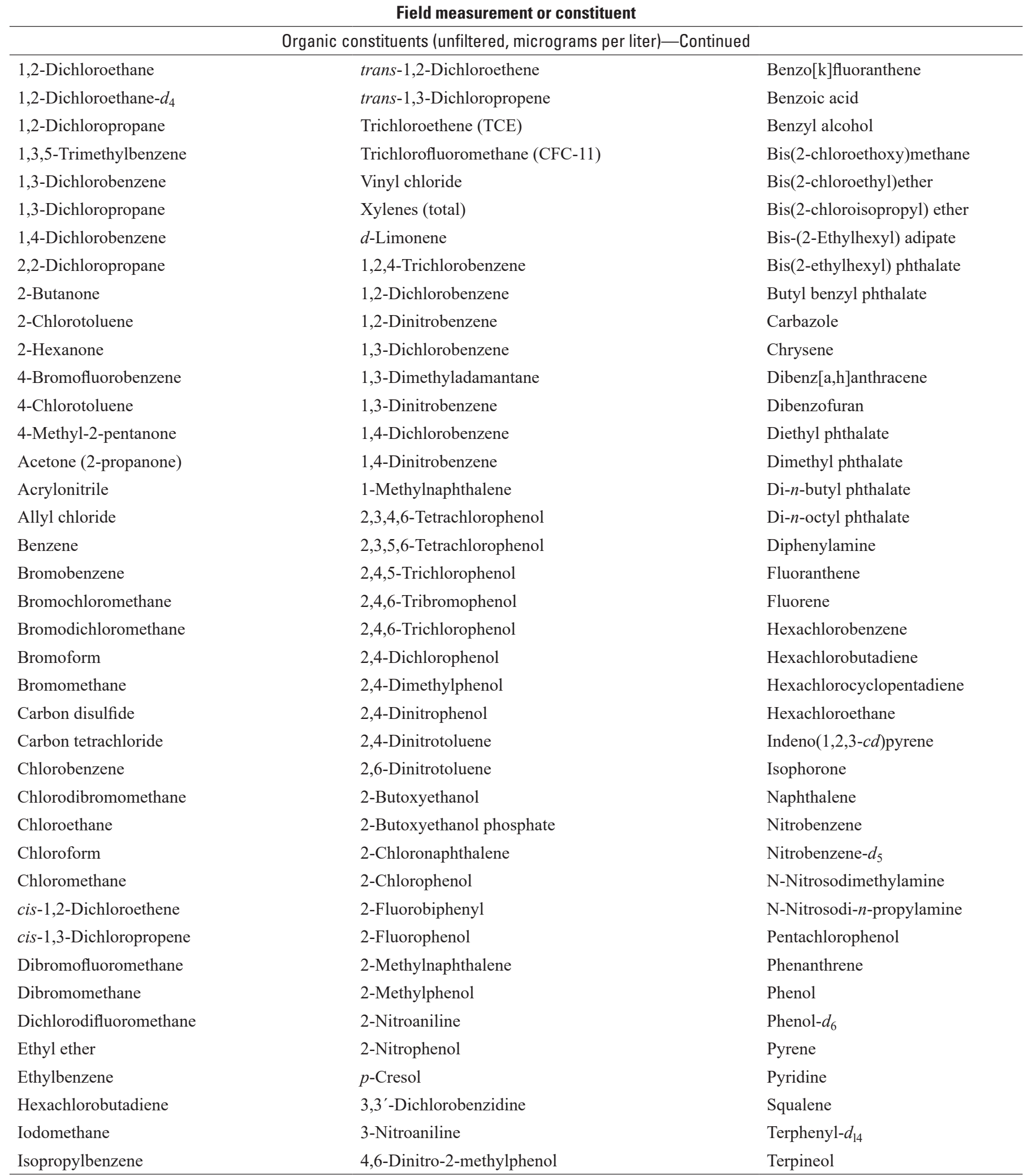


closely approximate the bioavailable fraction in the water column than total recoverable metals (U.S. Environmental Protection Agency, 1994). The EPA recommends that State water-quality standards be based on dissolved metals. Thus, the dissolved fractions of aluminum, arsenic, iron, and manganese are presented.

All water-quality data collected on the reservation during 2014-17 can be accessed from the Water Quality Portal database (National Water Quality Monitoring Council, 2018). Water-quality data analyzed by the USGS National Water Quality Laboratory and streamflow data also can be accessed from the USGS NWIS database using site numbers in tables 1 and 2 (U.S. Geological Survey, 2017).

Quality-assurance samples were collected to estimate reproducibility and potential for bias. Quality-assurance samples included 5 equipment blanks, 1 field blank, and 1 replicate sample. Equipment blanks were collected and reviewed prior to collection of the first environmental sample of the year. Equipment blanks were collected in a controlled environment to determine if the cleaning procedures for sample containers, sample collection equipment, and sample-processing procedures are sufficient to produce contaminant-free samples. Equipment blanks were collected from the surface-water sampling equipment, groundwater pumps, and associated tubing. The equipment was recleaned prior to collection of environmental samples. Field blanks were collected from the surfacewater and groundwater sampling equipment in the field at a sampling site.

The replicate sample was analyzed to assess variability in sample processing and analytical methods. The analytical variability of replicate samples for constituents was assessed using relative percent difference (calculated as the absolute difference in concentration divided by the mean concentration multiplied by 100 for the environmental/replicate sample pair). Relative percent differences for dissolved chloride, dissolved solids, sodium, sulfate, aluminum, arsenic, iron, manganese, ammonia, nitrate, and nitrite were all less than 10 percent (table 1.1), indicating satisfactory quality assurance on these constituents. Overall, the equipment blanks were satisfactory (near or less than detection level) with the exception of dissolved organic carbon and diesel range organics that had detections of $2,290 \mathrm{mg} / \mathrm{L}$ and $52.6 \mu \mathrm{g} / \mathrm{L}$, respectively (table 1.2). The organic carbon detection was likely from residual methanol remaining during the cleaning procedure. The equipment blanks collected before and after this sample had nondetects for organic carbon, and results for environmental samples collected afterwards were in the same range as other environmental samples, indicating that field rinsing removed any remaining methanol.

Quality-assurance sample data analyzed at the EPA Region 8 Laboratory can be accessed from the Water Quality Portal database (National Water Quality Monitoring Council, 2018). Quality-assurance sample data for the 11 constituents selected for additional discussion are presented in table 1.1. The quality-assurance sample data for the constituents not selected for additional discussion are presented in table 1.2.

\section{Water-Quality Data Analyses}

Summary statistics (minimum, median, and maximum) for concentrations of all 232 compounds are presented in table 1.3. Several of the water-quality constituents had varying reporting levels. The reporting level is the "less than" value reported when concentrations are too low to be accurately quantified. The reporting level can change through time and among laboratories because of changes in sensitivity of laboratory equipment, changes in analytical methods, or changes in protocol for determining the reporting level. The reporting level is generally higher than the method detection limit, which is the lowest concentration for which a compound can be detected (but not necessarily accurately quantified; Childress and others, 1999). Summary statistics were determined based solely on the detected concentrations. The "less than" values were not included in the summary statistics and, therefore, a "less than" value was indicated as a nondetect. The number of nondetects can be determined by subtracting the number of detections from the number of samples. Reporting levels for the 11 selected constituents in surface water and groundwater, along with the most common reporting level, are summarized in table 4 . Water-quality concentrations for groundwater samples of the 11 selected water-quality constituents were mapped using a geographic information system to represent the spatial distribution across the reservation.

Selected water-quality constituents were compared to EPA drinking water maximum contaminant levels (MCLs), secondary drinking water regulations (SDWRs), and drinking water equivalent levels (U.S. Environmental Protection Agency, 2018). An MCL is an enforceable standard that refers to the highest level or concentration that is allowed in drinking water for protection of health. An SDWR is a nonenforceable guideline and addresses either cosmetic or aesthetic effects, such as taste, odor, and color. A drinking water equivalent level is a lifetime exposure concentration protective of adverse, noncancer health effects, that assumes all of the exposure to a contaminant is from drinking water. USGS health-based screening levels also were included and are nonenforceable benchmark concentrations of contaminants in water (Norman and others, 2018). These health-based screening levels supplement Federal drinking-water standards and guidelines, which are not available for many of the hundreds of contaminants analyzed in sources of drinking water. Using health-based screening levels can provide a human-health context when evaluating the quality of sources of drinking water and can help prioritize monitoring efforts. The drinking water-quality standards and health-based screening levels are summarized in table 5 . If multiple drinking water-quality standards and health-based screening levels were available for a constituent, the one with the lowest value was used for comparisons.

Chloride concentrations were analyzed to determine if concentrations exceeded the EPA SDWR of 250 milligrams per liter $(\mathrm{mg} / \mathrm{L}$; table 5$)$. Chloride is present in all natural waters, but generally at low concentrations (Hem, 1985). In 
Table 4. Laboratory reporting levels for selected water-quality constituents in surface water and groundwater on Fort Berthold Reservation, North Dakota, 2014-17.

$\left[\mathrm{Cl}\right.$, chloride; <, less than; *, most of the analytical results used this laboratory reporting level; $\mathrm{Na}$, sodium; $\mathrm{SO}_{4}$, sulfate; $\mathrm{Al}$, aluminum; As, arsenic; $\mathrm{Fe}$, iron; Mn, manganese]

\begin{tabular}{ll}
\hline \multicolumn{1}{c}{ Constituent } & \multicolumn{1}{c}{ Reporting levels } \\
\hline Chloride, dissolved (milligrams per liter as $\mathrm{Cl}$ ) & $<0.2^{*},<2,4$ \\
Dissolved solids, residue on evaporation at 180 degrees Celsius & $<2$ \\
$\quad$ (milligrams per liter) & $<500^{*},<1,000,<5,000,<10,000$ \\
Sodium, dissolved (milligrams per liter as Na) & $<0.5^{*},<5,<10,<25,<50$ \\
Sulfate, dissolved (milligrams per liter as $\mathrm{SO}_{4}$ ) & $<100$ \\
Aluminum, dissolved (micrograms per liter as Al) & $<1,<2^{*},<4,<5$ \\
Arsenic, dissolved (micrograms per liter as As) & $<100$ \\
Iron, dissolved (micrograms per liter as Fe) & $<2$ \\
Manganese, dissolved (micrograms per liter as Mn) & $<0.025^{*},<0.05$ \\
Ammonia, dissolved (milligrams per liter as nitrogen) & $<0.005$ \\
Nitrate, dissolved (milligrams per liter as nitrogen) & $<0.005$ \\
Nitrite, dissolved (milligrams per liter as nitrogen) & \\
\hline
\end{tabular}

most surface streams, chloride concentrations are lower than those of sulfate or bicarbonate. Exceptions are where streams receive inflows of high-chloride groundwater, industrial waste, or are affected by oceanic tides.

Dissolved solids concentrations were analyzed to determine if concentrations exceeded the EPA SDWR of $500 \mathrm{mg} / \mathrm{L}$ (table 5). Dissolved solids are an important constituent to water purveyors and users because high concentrations of dissolved solids can cause changes to the taste of water and could have undesirable effects for hospitals, industrial facilities, and stream ecosystems (Hem, 1985). Dissolved solids in surface water result from natural dissolution of rocks and minerals or discharges from municipal, industrial, or agricultural sources (Hem, 1985). The primary constituents of dissolved solids are the cations (positively charges ions) calcium, magnesium, sodium, and potassium; the anions (negatively charged ions) sulfate, chloride, fluoride, nitrate, and those contributing to alkalinity; and several other constituents that are present in small quantities. Natural variability in dissolved solids concentrations depends on chemical characteristics of drainage-basin soils; composition of surficial material; and in some situations, the minerals in deeper geologic strata. Dissolved solids concentrations may be affected by different constituents in different locations in North Dakota. Usually the changes in dissolved solids concentrations are somewhat related to the rate of water streamflow and the rate of change of streamflow, but this correlation is complicated by other factors related to the hydrology and the geochemistry of the system (Hem, 1985).

Sodium concentrations were analyzed to determine if concentrations exceeded the taste threshold of $30 \mathrm{mg} / \mathrm{L}$ (table 5). Sodium tends to remain in solution when dissolved from weathering rocks and does not form precipitates that can reduce dissolved sodium concentrations (Hem, 1985). Cationexchange processes in freshwater systems tend to extract divalent ions from solution and replace them with monovalent ions, especially sodium (Hem, 1985). Also, sodium salts used for deicing roads can be transported to streams in runoff (Hem, 1985).

Sulfate concentrations were analyzed to determine if concentrations exceeded the EPA SDWR of $250 \mathrm{mg} / \mathrm{L}$ (table 5). Sulfate is an oxidized form of sulfur and occurs naturally in surface water as a result of weathering of metallic sulfides in igneous and sedimentary rocks (Hem, 1985). Soils across North Dakota have naturally high sulfur content that readily oxidizes to highly soluble sulfate ions (Franzen, 2019). Sulfate in streams may be affected by land-use changes that can increase or decrease the exposure of naturally occurring sulfur to surface runoff. In addition to natural sources, sulfate concentrations in streams may be increased as a result of human activities. The release of sulfur dioxide during the combustion of fossil fuels may increase stream sulfate concentrations (Smith and Alexander, 1986). The conversion of sulfur dioxide to particulate sulfate is assumed to be an aqueous-enhanced chemical reaction in the atmosphere (Lamb and others, 1987). Subsequent wet and dry deposition may increase concentrations of sulfate in surface water. High concentrations of sulfate affect the taste of drinking water and may cause laxative effects (Hem, 1985).

Aluminum concentrations were analyzed to determine if concentrations exceeded the EPA SDWR of 50 micrograms per liter $(\mu \mathrm{g} / \mathrm{L}$; table 5). Aluminum is the third-most abundant element in the Earth's outer crust but rarely is detected in solution in natural water in a concentration greater than a few tenths or hundredths of a microgram per liter (Hem, 1985). Most natural waters have ample opportunity to dissolve aluminum because it is so abundant and so widely distributed (Hem, 1985). Aluminum, when present in high concentrations such as downstream from industrial point sources of aluminum-rich 
Table 5. Drinking water-quality standards and health-based screening levels available for water-quality constituents analyzed on Fort Berthold Reservation, North Dakota, $2014-17$.

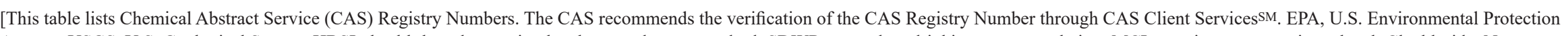
Agency; USGS, U.S. Geological Survey; HBSL, health-based screening level; --, no data or standard; SDWR, secondary drinking water regulation; MCL, maximum contaminant level; Cl, chloride; Na, sodium; F, fluoride; $\mathrm{SO}_{4}$, sulfate; Al, aluminum; $\mathrm{Sb}$, antimony; As, arsenic; $\mathrm{Ba}$, barium; Be, beryllium; B, boron; DWEL, drinking water equivalent level; Cd, cadmium; $\mathrm{Cr}$, chromium; Co, cobalt; $\mathrm{Cu}$, copper; $\mathrm{Fe}$, iron; $\mathrm{Pb}$, lead; Mn, manganese; Mo, molybdenum; Ni, nickel; Se, selenium; Ag, silver; Sr, strontium; Ti, thallium; V, vanadium; $\mathrm{Zn}$, zinc]

\begin{tabular}{|c|c|c|c|c|}
\hline \multirow{2}{*}{ Field measurement or constituent } & \multirow{2}{*}{$\begin{array}{c}\text { CAS } \\
\text { Registry } \\
\text { Number }\end{array}$} & \multicolumn{2}{|c|}{$\begin{array}{c}\text { EPA } \\
\text { water-quality standard1 }\end{array}$} & \multirow{2}{*}{$\begin{array}{c}\text { USGS } \\
\text { benchmarks }^{2} \\
\begin{array}{c}\text { Noncancer } \\
\text { HBSL }\end{array} \\
\end{array}$} \\
\hline & & $\begin{array}{c}\text { Water-quality } \\
\text { standard }\end{array}$ & $\begin{array}{l}\text { Water-quality } \\
\text { standard type }\end{array}$ & \\
\hline \multicolumn{5}{|c|}{ Field measurements } \\
\hline Field $\mathrm{pH}$ (standard units) & -- & $6.5-8.5$ & SDWR & -- \\
\hline Turbidity, field measurement, unfiltered water (formazin nephelometric unit) & -- & 5 & MCL & -- \\
\hline \multicolumn{5}{|c|}{ Major ions (dissolved is the sample filtered in the laboratory through 0.45 -micrometer filter) } \\
\hline Chloride, dissolved (milligrams per liter as $\mathrm{Cl}$ ) & $16887-00-6$ & 250 & SDWR & -- \\
\hline Dissolved solids, residue on evaporation at 180 degrees Celsius (milligrams per liter) & -- & 500 & SDWR & -- \\
\hline Sodium, dissolved (milligrams per liter as $\mathrm{Na}$ ) & $7440-23-5$ & 30 & Taste threshold & -- \\
\hline Fluoride, dissolved (milligrams per liter as F) & $7681-49-4$ & 4 & MCL & -- \\
\hline Sulfate, dissolved (milligrams per liter as $\mathrm{SO}_{4}$ ) & 14808-79-8 & 250 & SDWR & -- \\
\hline \multicolumn{5}{|c|}{ Trace elements (dissolved is the sample filtered in the field through 0.45 -micrometer disposable cartridge filter) } \\
\hline Aluminum, dissolved (micrograms per liter as $\mathrm{Al}$ ) & $7429-90-5$ & 50 & SDWR & 6,000 \\
\hline Antimony, dissolved (micrograms per liter as $\mathrm{Sb}$ ) & $7440-36-0$ & 6 & MCL & -- \\
\hline Arsenic, dissolved (micrograms per liter as As) & $7440-38-2$ & 10 & MCL & -- \\
\hline Barium, dissolved (micrograms per liter as $\mathrm{Ba}$ ) & $7440-39-3$ & 2,000 & MCL & -- \\
\hline Beryllium, dissolved (micrograms per liter as Be) & $7440-41-7$ & 4 & MCL & -- \\
\hline Boron, dissolved (micrograms per liter as B) & $7440-42-8$ & 7,000 & DWEL & 5,000 \\
\hline Cadmium, dissolved (micrograms per liter as Cd) & $7440-43-9$ & 5 & MCL & -- \\
\hline Chromium, dissolved (micrograms per liter as $\mathrm{Cr}$ ) & $7440-47-3$ & 100 & MCL & -- \\
\hline Cobalt, dissolved (micrograms per liter as $\mathrm{Co}$ ) & $7440-48-4$ & -- & -- & 2 \\
\hline Copper, dissolved (micrograms per liter as $\mathrm{Cu}$ ) & $7440-50-8$ & 1,300 & MCL & -- \\
\hline Iron, dissolved (micrograms per liter as Fe) & $7439-89-6$ & 300 & SDWR & 4,000 \\
\hline Lead, dissolved (micrograms per liter as $\mathrm{Pb}$ ) & $7439-92-1$ & 15 & MCL & -- \\
\hline Manganese, dissolved (micrograms per liter as $\mathrm{Mn}$ ) & $7439-96-5$ & 50 & SDWR & 300 \\
\hline Molybdenum, dissolved (micrograms per liter as Mo) & 7439-98-7 & 200 & DWEL & 30 \\
\hline Nickel, dissolved (micrograms per liter as Ni) & $7440-02-0$ & 700 & DWEL & 100 \\
\hline Selenium, dissolved (micrograms per liter as Se) & $7782-49-2$ & 50 & MCL & -- \\
\hline
\end{tabular}


Table 5. Drinking water-quality standards and health-based screening levels available for water-quality constituents analyzed on Fort Berthold Reservation, North Dakota, 2014-17.-Continued

[This table lists Chemical Abstract Service (CAS) Registry Numbers. The CAS recommends the verification of the CAS Registry Number through CAS Client ServicesSM. EPA, U.S. Environmental Protection Agency; USGS, U.S. Geological Survey; HBSL, health-based screening level; --, no data or standard; SDWR, secondary drinking water regulation; MCL, maximum contaminant level; Cl, chloride; Na, sodium; F, fluoride; $\mathrm{SO}_{4}$, sulfate; $\mathrm{Al}$, aluminum; Sb, antimony; As, arsenic; Ba, barium; Be, beryllium; B, boron; DWEL, drinking water equivalent level; Cd, cadmium; Cr, chromium; Co, cobalt; Cu, copper; $\mathrm{Fe}$, iron; $\mathrm{Pb}$, lead; Mn, manganese; Mo, molybdenum; Ni, nickel; Se, selenium; Ag, silver; Sr, strontium; Ti, thallium; V, vanadium; Zn, zinc]

\begin{tabular}{|c|c|c|c|c|}
\hline \multirow{2}{*}{ Field measurement or constituent } & \multirow{2}{*}{$\begin{array}{c}\text { CAS } \\
\text { Registry } \\
\text { Number }\end{array}$} & \multicolumn{2}{|c|}{$\begin{array}{c}\text { EPA } \\
\text { water quality standard1 }\end{array}$} & \multirow{2}{*}{$\begin{array}{c}\begin{array}{c}\text { USGS } \\
\text { benchmarks }\end{array} \\
\begin{array}{c}\text { Noncancer } \\
\text { HBSL }\end{array}\end{array}$} \\
\hline & & $\begin{array}{l}\text { Water-quality } \\
\text { standard }\end{array}$ & $\begin{array}{l}\text { Water-quality } \\
\text { standard type }\end{array}$ & \\
\hline \multicolumn{5}{|c|}{ Trace elements (dissolved is the sample filtered in the field through 0.45 -micrometer disposable cartridge filter)—Continued } \\
\hline Silver, dissolved (micrograms per liter as Ag) & $7440-22-4$ & 100 & SDWR & 100 \\
\hline Strontium, dissolved (micrograms per liter as $\mathrm{Sr}$ ) & $7440-24-6$ & 20,000 & DWEL & 4,000 \\
\hline Thallium, dissolved (micrograms per liter as Ti) & $7440-28-0$ & 2 & MCL & -- \\
\hline Uranium, natural, dissolved (micrograms per liter) & $7440-61-1$ & 30 & MCL & -- \\
\hline Vanadium, dissolved (micrograms per liter as V) & $7440-62-2$ & -- & -- & 0.4 \\
\hline Zinc, dissolved (micrograms per liter as Zn) & $7440-66-6$ & 5,000 & SDWR & 2,000 \\
\hline \multicolumn{5}{|c|}{ Nutrients (dissolved is the sample filtered in the field through 0.45 -micrometer disposable cartridge filter) } \\
\hline Ammonia, dissolved (milligrams per liter as nitrogen) & $7664-41-7$ & 30 & Taste threshold & -- \\
\hline Nitrate, dissolved (milligrams per liter as nitrogen) & $14797-55-8$ & 10 & MCL & -- \\
\hline Nitrite, dissolved (milligrams per liter as nitrogen) & $14797-65-0$ & 1 & MCL & -- \\
\hline Nitrate plus nitrite, dissolved (milligrams per liter as nitrogen) & -- & 10 & -- & -- \\
\hline \multicolumn{5}{|c|}{ Organic constituents } \\
\hline 1,2 Dichloroethane, unfiltered, recoverable (micrograms per liter) & $107-06-2$ & 5 & MCL & -- \\
\hline 1,2 Dichloropropane, unfiltered, recoverable (micrograms per liter) & $78-87-5$ & 5 & MCL & -- \\
\hline Acetone, unfiltered, recoverable (micrograms per liter) & $67-64-1$ & -- & -- & 6,000 \\
\hline Benzene, unfiltered, recoverable (micrograms per liter) & $71-43-2$ & 5 & MCL & -- \\
\hline Bromoform, unfiltered, recoverable (micrograms per liter) & $75-25-2$ & 80 & MCL & -- \\
\hline Carbon disulfide, unfiltered, recoverable (micrograms per liter) & $75-15-0$ & -- & -- & -- \\
\hline Carbon tetrachloride, unfiltered, recoverable (micrograms per liter) & $56-23-5$ & 5 & MCL & -- \\
\hline Chloroform, unfiltered, recoverable (micrograms per liter) & $67-66-3$ & 80 & MCL & -- \\
\hline Ethlybenzene, unfiltered, recoverable (micrograms per liter) & $100-41-4$ & 700 & MCL & -- \\
\hline Hexachlorobenzene, unfiltered, recoverable (micrograms per liter) & $118-74-1$ & 1 & MCL & -- \\
\hline Hexachlorocyclopentadiene, unfiltered, recoverable (micrograms per liter) & $77-47-4$ & 50 & MCL & -- \\
\hline Pentachlorophenol, unfiltered, recoverable (micrograms per liter) & $87-86-5$ & 1 & MCL & -- \\
\hline
\end{tabular}


Table 5. Drinking water-quality standards and health-based screening levels available for water-quality constituents analyzed on Fort Berthold Reservation, North Dakota, 2014-17.-Continued

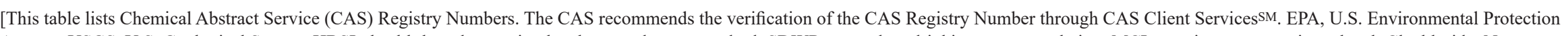
Agency; USGS, U.S. Geological Survey; HBSL, health-based screening level; --, no data or standard; SDWR, secondary drinking water regulation; MCL, maximum contaminant level; Cl, chloride; Na, sodium; F, fluoride; $\mathrm{SO}_{4}$, sulfate; Al, aluminum; $\mathrm{Sb}$, antimony; $\mathrm{As}$, arsenic; $\mathrm{Ba}$, barium; Be, beryllium; B, boron; DWEL, drinking water equivalent level; $\mathrm{Cd}$, cadmium; Cr, chromium; Co, cobalt; Cu, copper; $\mathrm{Fe}$, iron; $\mathrm{Pb}$, lead; Mn, manganese; Mo, molybdenum; Ni, nickel; Se, selenium; Ag, silver; Sr, strontium; Ti, thallium; V, vanadium; Zn, zinc]

\begin{tabular}{|c|c|c|c|c|}
\hline \multirow{2}{*}{ Field measurement or constituent } & \multirow{2}{*}{$\begin{array}{c}\text { CAS } \\
\text { Registry } \\
\text { Number }\end{array}$} & \multicolumn{2}{|c|}{$\begin{array}{c}\text { EPA } \\
\text { water quality standard1 }\end{array}$} & \multirow{2}{*}{$\begin{array}{c}\text { USGS } \\
\text { benchmarks } \\
\begin{array}{c}\text { Noncancer } \\
\text { HBSL }\end{array}\end{array}$} \\
\hline & & $\begin{array}{l}\text { Water-quality } \\
\text { standard }\end{array}$ & $\begin{array}{l}\text { Water-quality } \\
\text { standard type }\end{array}$ & \\
\hline \multicolumn{5}{|c|}{ Organic constituents-Continued } \\
\hline Styrene, unfiltered, recoverable (micrograms per liter) & $100-42-5$ & 100 & MCL & -- \\
\hline Toluene, unfiltered, recoverable (micrograms per liter) & $108-88-3$ & 1,000 & MCL & -- \\
\hline 1,2,4-Trichlorobenzene, unfiltered, recoverable (micrograms per liter) & $120-82-1$ & 70 & MCL & -- \\
\hline Vinyl chloride, unfiltered, recoverable (micrograms per liter) & $75-01-4$ & 2 & MCL & -- \\
\hline Xylenes, unfiltered, recoverable (micrograms per liter) & $1330-20-7$ & 10,000 & MCL & -- \\
\hline
\end{tabular}

${ }^{1}$ U.S. Environmental Protection Agency, 2018.

2Norman and others, 2018. 
process water, has been recognized as a toxic agent to aquatic freshwater organisms (Hem, 1985). The environmental effects of aluminum are mainly a result of acidic precipitationacidification of catchments leads to increased aluminum concentrations in soil solution and freshwaters. In the aquatic environment, aluminum acts as a toxic agent on gill-breathing animals such as fish and invertebrates. Aluminum also seems to accumulate in freshwater invertebrates (Rosseland and others, 1990).

Arsenic concentrations were analyzed to determine if concentrations exceeded the EPA MCL of $10 \mu \mathrm{g} / \mathrm{L}$ (table 5). Arsenic occurs naturally as a trace component in many rocks and sediments. Arsenic has been used as a component of pesticides and may enter streams or groundwater through waste disposal or agricultural drainage (Hem, 1985). An important factor in the natural circulation of arsenic is the volatility of the element and some of its compounds (Hem, 1985). Discharge of arsenic-enriched groundwater may contaminate surface-water resources. If the arsenic is released from these geologic sources into groundwater depends on the chemical form of the arsenic, the geochemical conditions in the aquifer, and the biogeochemical processes that occur. Arsenic also can be released into groundwater as a result of human activities such as mining, various uses in industry, animal feed, and wood preservatives.

In a national study of groundwater quality, USGS researchers documented that arsenic was detected in nearly one-half of the wells sampled in parts of aquifers used for drinking-water supply at a concentration of $1 \mu \mathrm{g} / \mathrm{L}$ or greater (DeSimone and others, 2014). As part of the national study, a regional assessment was completed for water quality in the glacial aquifer system that underlies much of the northern United States (Warner and Ayotte, 2014). The primary importance of the glacial aquifer system is as a source of water for public supply to the population centers in the region, but the aquifer system also provides drinking water for domestic use to individual homes and small communities in rural areas. Results of the national study indicated that contaminants from geologic sources, most notably arsenic and manganese, were detected at concentrations of potential concern for human health in 20 percent of samples of untreated drinking watermore than three times as frequently as contaminants from human activities. Consumption of drinking water containing high concentrations of arsenic and manganese has been associated with carcinogenic and neurological effects (Hem, 1985).

Concentrations of arsenic and manganese in the glacial aquifer system are among the highest in the Nation (DeSimone and others, 2014).

Iron concentrations were analyzed to determine if concentrations exceeded the EPA SDWR $300 \mu \mathrm{g} / \mathrm{L}$ (table 5). Iron occurs from the decomposition of some rocks and in mine runoff. Iron can affect the suitability of water for public and industrial water supply and can harm aquatic organisms. The higher concentrations sometimes reported in such waters generally are particulates (Kennedy and others, 1974) small enough to pass through 0.45 -micrometer porosity filter membranes (Hem, 1985). The most common form of iron in solution in groundwater is the ferrous ion.

Manganese concentrations were analyzed to determine if concentrations exceeded the EPA SDWR of $50 \mu \mathrm{g} / \mathrm{L}$ (table 5). The chemistry of manganese is similar to iron in that both metals participate in redox processes in weathering environments (Hem, 1985). Manganese is a naturally occurring substance present in many types of rocks and soil. As with other elements, manganese cannot break down in the environment. Manganese can only change its form or become attached or separated from particles. In water, most of the manganese tends to attach to particles in the water or settle into the sediment. Manganese is not present in the environment as a pure metal, but rather is combined with other substances such as oxygen, sulfur, and chlorine (Hem, 1985).

Ammonia, nitrate, and nitrite are inorganic forms of nitrogen commonly associated with agricultural land use (Hem, 1985). As fertilizers are applied to the land surface, plants eventually take up these mineral forms through their root systems and form plant proteins and other organic forms of nitrogen. Livestock eat crops and produce manure, which is returned to the soil, adding organic and mineral forms of nitrogen to the soil, which can be used again by the next crop. As such, these sources of nitrogen may, in part, affect the water resources of the reservation.

\section{Characterization of Water Quality on the Fort Berthold Reservation}

The intent of the reservation water-quality monitoring program for surface water and groundwater is to provide a scientific understanding of current (2019) conditions that may be used to evaluate potential effects from agricultural and energy development land uses. The program was not designed for compliance monitoring. However, comparisons to available water-quality standards were provided. Water-quality data for surface water and groundwater on the reservation are described in terms of summary statistics on constituent concentrations. Eleven constituents considered to be indicators of surface-water and groundwater quality on the reservation were selected for analysis. The constituents were selected based on their common association with agricultural and energy development land uses. These constituents are chloride, dissolved solids, sodium, sulfate, aluminum, arsenic, iron, manganese, ammonia, nitrate, and nitrite. Samples also were analyzed for additional constituents that are generally categorized as major ions, nutrients, trace elements, and organic compounds. Constituents in these categories generally were not detected or were detected infrequently. Therefore, these constituents are not discussed in this report, but the data are provided in tables 1.3 and 1.5. 


\section{Surface-Water Quality}

Streamflow and surface-water-quality data were collected from six surface-water sites on the reservation during May 2014 through October 2017. Historical streamflow data are available from the USGS NWIS database (U.S. Geological Survey, 2017; table 6) and water-quality data are available from the Water Quality Portal database (National Water Quality Monitoring Council, 2018) and NWIS database (table 1.4) for various periods from 1966 to April 2014. The six surface-water sites represent the six major drainages that are on and around the reservation and that flow into Lake Sakakawea (fig. 1). The streams on the reservation generally are ephemeral and have extended periods of no flow. The six surface-water sites were sampled two times during 2014 (May and August) and four times per year (April, June, August, and October) during 2015-17. Water-quality sampling frequency and timing during 2015-17 was based on a design described as "level 3" sites in Galloway and others (2012) and similar to the North Dakota statewide sampling network that is operated by the North Dakota Department of Environmental Quality, the USGS, and the North Dakota State Water Commission (Joel Galloway, U.S. Geological Survey, written commun., 2019).

Streamflow data and water-quality samples are needed to understand the chemistry, loads, and trends in the streams. Data from the six surface-water sites help hydrologists to better understand the hydrology and water quality on the reservation. Streamflow either was continuously recorded from an existing streamgaging station or instantaneously measured concurrently with each sample collected. Daily mean streamflows for the three continuous-recording USGS streamgaging stations generally were higher during spring snowmelt and rainfall from April through June and generally were lower during fall and winter from October through March. This pattern is represented in figure 2 for the streamgaging station Bear Den Creek near Mandaree, N. Dak. (USGS station number 06332515$)$. The water-quality samples collected during 2014-17 also were displayed on figure 2 to show the range of streamflow during sample collection. In this case, streamflow ranged from less than 0.01 to 10 cubic feet per second. Historically, streamflows at the six sites ranged from a minimum of less than 0.01 cubic foot per second at several sites to a maximum of 1,570 cubic feet per second at the streamgaging station Shell Creek near Parshall, N. Dak. (USGS station number 06332520; table 6). The surface-water site that had the most historical streamflow measurements was the streamgaging station Bear Den Creek near Mandaree, N. Dak. (USGS station number 06332515; table 6).

Summary statistics for the 11 selected constituents in surface water are presented in table 7. Summary statistics for all constituents analyzed in surface water are presented in table 1.3. Summary statistics for historical water-quality constituents are presented in table 1.4. In general, higher concentrations of these 11 selected constituents may be attributed to low streamflow conditions. However, analyses of the relation between streamflow characteristics and water quality (loads and trends) is beyond the scope of this report.

The major ions that were selected for detailed discussion are dissolved chloride, dissolved solids, dissolved sodium, and dissolved sulfate. Each of these constituents were detected in all samples collected at the six surface-water sites (table 7). Dissolved chloride concentrations in all samples were less than the EPA SDWR of $250 \mathrm{mg} / \mathrm{L}$ (tables 5, 7). When detected, the median dissolved chloride concentrations ranged from $4.3 \mathrm{mg} / \mathrm{L}$ at streamgaging station Squaw Creek above mouth near Mandaree, N. Dak. (USGS station number 06337480) to $24.9 \mathrm{mg} / \mathrm{L}$ at streamgaging station East Fork Shell Creek near Parshall, N. Dak. (USGS station number 06332523; table 7). Dissolved solids concentrations exceeded the EPA SDWR of $500 \mathrm{mg} / \mathrm{L}$ in all samples from each site (tables 5,7 ). The median dissolved solids concentrations tended to be greater in the western part of the reservation and lower in the eastern part of the reservation (table 7, fig. 1). The median dissolved solids concentrations ranged from $1,260 \mathrm{mg} / \mathrm{L}$ at streamgaging station Deepwater Creek at mouth near Raub, N. Dak. (USGS station number 06332770 ) to $3,370 \mathrm{mg} / \mathrm{L}$ at the Squaw Creek streamgaging station (USGS station number 06337480;

Table 6. Summary statistics for historical streamflow measurements at surface-water sites on Fort Berthold Reservation, North Dakota, October 1973 to April 2014.

[Data available from U.S. Geological Survey (USGS) National Water Information System database (U.S. Geological Survey, 2017). <, less than]

\begin{tabular}{|c|c|c|c|c|c|c|}
\hline \multirow{2}{*}{$\begin{array}{c}\text { USGS } \\
\text { station number } \\
\text { (fig. 1) }\end{array}$} & \multirow{2}{*}{$\begin{array}{c}\text { Number of } \\
\text { streamflow } \\
\text { measurements }\end{array}$} & \multicolumn{3}{|c|}{ Streamflow, in cubic feet per second } & \multirow{2}{*}{ Begin date } & \multirow[b]{2}{*}{ End date } \\
\hline & & Minimum & Median & Maximum & & \\
\hline 06332515 & 318 & 0.01 & 0.25 & 1,100 & $11 / 1 / 1973$ & $03 / 24 / 2014$ \\
\hline 06332520 & 99 & 0.02 & 2.5 & 1,570 & $10 / 1 / 1973$ & 09/03/1981 \\
\hline 06332523 & 117 & 0.01 & 1.8 & 542 & 07/10/1991 & $08 / 21 / 2013$ \\
\hline 06332770 & 115 & 0.02 & 2.2 & 921 & $04 / 18 / 1990$ & $06 / 19 / 2013$ \\
\hline 06337480 & 18 & $<0.1$ & 0.025 & 60 & 04/18/1990 & 08/11/1993 \\
\hline
\end{tabular}




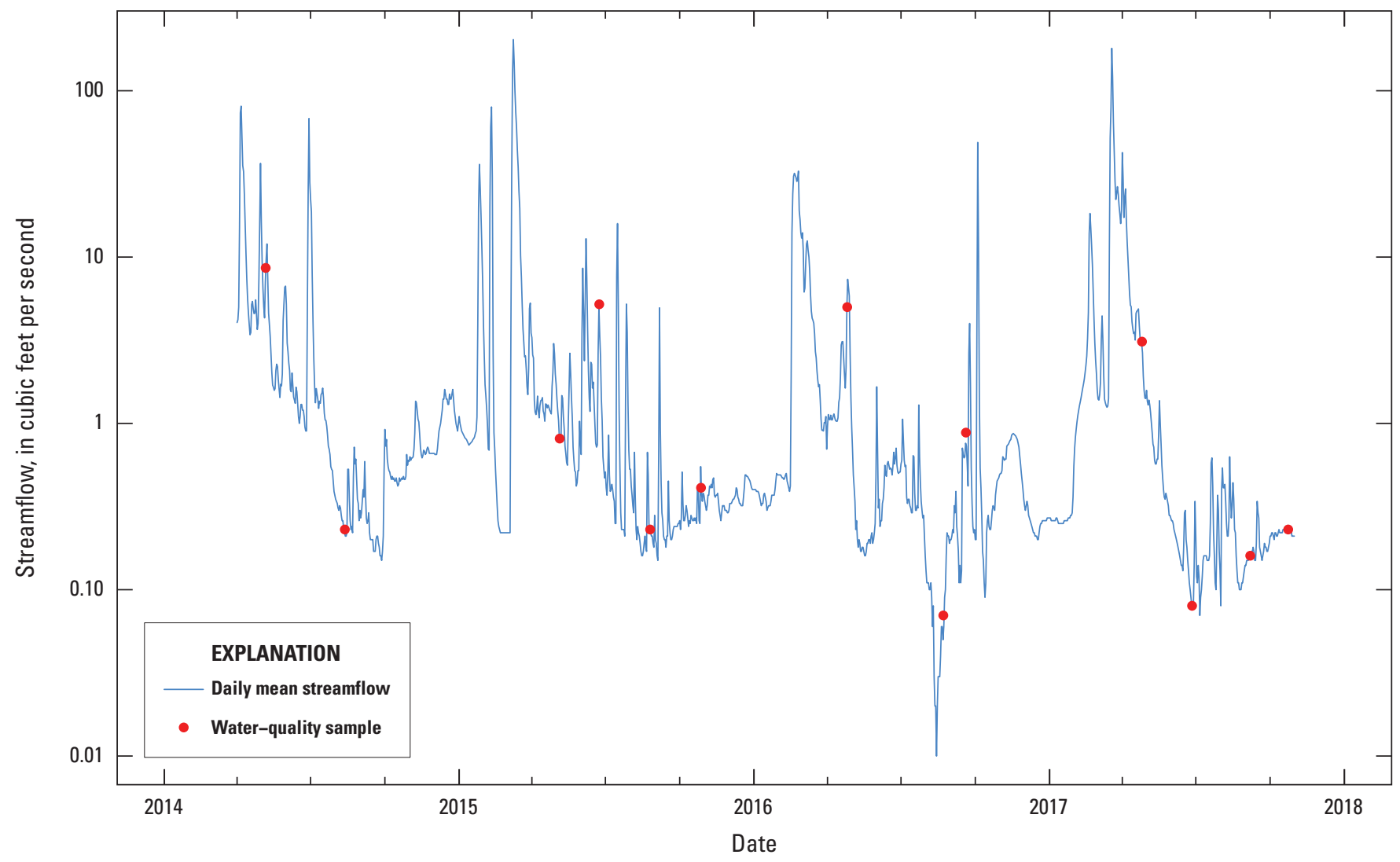

Figure 2. Daily mean streamflow and water-quality samples collected at streamgaging station Bear Den Creek near Mandaree, North Dakota (U.S. Geological Survey station number 06332515), 2014-17.

table 7). Dissolved sodium concentrations exceeded the EPA taste threshold of $30 \mathrm{mg} / \mathrm{L}$ in all samples from each site (tables 5, 7). The median dissolved sodium concentrations ranged from $268 \mathrm{mg} / \mathrm{L}$ at the Deepwater Creek streamgaging station (USGS station number 06332770 ) to $1,007 \mathrm{mg} / \mathrm{L}$ at the Squaw Creek streamgaging station (USGS station number 06337480; table 7). Dissolved sulfate concentrations exceeded the EPA SDWR of $250 \mathrm{mg} / \mathrm{L}$ in all samples from each site (tables 5, 7). The median dissolved sulfate concentrations ranged from $628 \mathrm{mg} / \mathrm{L}$ at the Deepwater Creek streamgaging station (USGS station number 06332770) to 2,065 $\mathrm{mg} / \mathrm{L}$ at the Squaw Creek streamgaging station (USGS station number 06337480; table 7).

Trace metals that were selected for discussion are dissolved aluminum, dissolved arsenic, dissolved iron, and dissolved manganese. Dissolved aluminum was detected in 17 samples collected during 2014-17 from the 6 surface-water sites (table 7). Of the detected concentrations, all exceeded the EPA SDWR of $50 \mu \mathrm{g} / \mathrm{L}$, and median dissolved aluminum concentrations ranged from 116 to $216 \mu \mathrm{g} / \mathrm{L}$ (table 7 ). Dissolved arsenic was detected in 58 samples collected during 2014-17 from the 6 surface-water sites at concentrations that were less than the EPA MCL of $10 \mu \mathrm{g} / \mathrm{L}$ (tables 5, 7). When detected, the median dissolved arsenic concentrations ranged from $2.0 \mu \mathrm{g} / \mathrm{L}$ at streamgaging station Moccasin Creek at mouth near Mandaree, N. Dak. (USGS station number 06337470) to $6.2 \mu \mathrm{g} / \mathrm{L}$ at the Deepwater Creek streamgaging station (USGS station number 06332770; table 7). Iron was detected in 22 samples collected from the 6 surface-water sites at concentrations that exceeded the EPA SDWR of $300 \mu \mathrm{g} / \mathrm{L}$ in 3 samples (table 7). When detected, the median dissolved iron concentrations ranged from $138 \mu \mathrm{g} / \mathrm{L}$ at the Deepwater Creek streamgaging station (USGS station number 06332770) to $250 \mu \mathrm{g} / \mathrm{L}$ at the Squaw Creek streamgaging station (USGS station number 06337480; table 7). Dissolved manganese was detected in 83 of 84 samples collected, and each of the 6 surface-water sites had samples with concentrations that exceeded the EPA SDWR of $50 \mu \mathrm{g} / \mathrm{L}$ (table 7). When detected, the median dissolved manganese concentrations ranged from $20.9 \mu \mathrm{g} / \mathrm{L}$ at the Moccasin Creek streamgaging station (USGS station number 06337470) to $122 \mu \mathrm{g} / \mathrm{L}$ at the Squaw Creek streamgaging station (USGS station number 06337480; table 7).

Nutrients that were selected are dissolved ammonia, dissolved nitrate, and dissolved nitrite. Dissolved ammonia was detected in seven samples at concentrations that were less than the EPA taste threshold of $30 \mathrm{mg} / \mathrm{L}$ (tables 5, 7). When detected, the median dissolved ammonia concentrations ranged from 0.1 to $0.5 \mathrm{mg} / \mathrm{L}$. Dissolved nitrate was detected in nine samples at concentrations that were less than 
Table 7. Summary statistics for selected water-quality constituents at surface-water sites on Fort Berthold Reservation, North Dakota, $2014-17$.

[USGS, U.S. Geological Survey; EPA, U.S. Environmental Protection Agency; SDWR, secondary drinking water regulation; nd, nondetect; MCL, maximum contaminant level]

\begin{tabular}{|c|c|c|c|c|c|c|c|c|}
\hline $\begin{array}{l}\text { USGS station } \\
\text { number } \\
\text { (fig. 1) }\end{array}$ & $\begin{array}{l}\text { Number of } \\
\text { samples }\end{array}$ & $\begin{array}{c}\text { EPA } \\
\text { water-quality } \\
\text { standard1 }\end{array}$ & $\begin{array}{c}\text { EPA } \\
\text { water-quality } \\
\text { standard type }\end{array}$ & Minimum & Median & Maximum & $\begin{array}{l}\text { Number of } \\
\text { detections }\end{array}$ & $\begin{array}{l}\text { Number of detections with a } \\
\text { concentration that exceeded } \\
\text { the water-quality standard }\end{array}$ \\
\hline \multicolumn{9}{|c|}{ Chloride, dissolved (milligrams per liter) } \\
\hline 06332515 & 14 & 250 & SDWR & 2.2 & 4.6 & 22.2 & 14 & 0 \\
\hline 06332520 & 14 & 250 & SDWR & 6.8 & 11.2 & 26.3 & 14 & 0 \\
\hline 06332523 & 14 & 250 & SDWR & 8.4 & 24.9 & 56.5 & 14 & 0 \\
\hline 06332770 & 14 & 250 & SDWR & 6.8 & 12.7 & 20.2 & 14 & 0 \\
\hline 06337470 & 14 & 250 & SDWR & 3.0 & 5.4 & 12.1 & 14 & 0 \\
\hline 06337480 & 14 & 250 & SDWR & 0.4 & 4.3 & 13.3 & 14 & 0 \\
\hline \multicolumn{9}{|c|}{ Dissolved solids, residue on evaporation at 180 degrees Celsius (milligrams per liter) } \\
\hline 06332515 & 13 & 500 & SDWR & 1,570 & 2,200 & 2,570 & 13 & 13 \\
\hline 06332520 & 13 & 500 & SDWR & 1,670 & 1,960 & 2,260 & 13 & 13 \\
\hline 06332523 & 13 & 500 & SDWR & 1,880 & 2,070 & 2,800 & 13 & 13 \\
\hline 06332770 & 13 & 500 & SDWR & 1,090 & 1,260 & 1,800 & 13 & 13 \\
\hline 06337470 & 13 & 500 & SDWR & 1,010 & 1,480 & 2,380 & 13 & 13 \\
\hline 06337480 & 13 & 500 & SDWR & 1,430 & 3,370 & 5,720 & 13 & 13 \\
\hline \multicolumn{9}{|c|}{ Sodium, dissolved (milligrams per liter as sodium) } \\
\hline 06332515 & 14 & 30 & Taste threshold & 452 & 620 & 740 & 14 & 14 \\
\hline 06332520 & 14 & 30 & Taste threshold & 314 & 508 & 624 & 14 & 14 \\
\hline 06332523 & 14 & 30 & Taste threshold & 185 & 515 & 665 & 14 & 14 \\
\hline 06332770 & 14 & 30 & Taste threshold & 143 & 268 & 385 & 14 & 14 \\
\hline 06337470 & 14 & 30 & Taste threshold & 265 & 373 & 2700 & 14 & 14 \\
\hline 06337480 & 14 & 30 & Taste threshold & 411 & 1,007 & 1,470 & 14 & 14 \\
\hline \multicolumn{9}{|c|}{ Sulfate, dissolved (milligrams per liter as sulfate) } \\
\hline 06332515 & 14 & 250 & SDWR & 700 & 1,045 & 1,490 & 14 & 14 \\
\hline 06332520 & 14 & 250 & SDWR & 694 & 878 & 1,210 & 14 & 14 \\
\hline 06332523 & 14 & 250 & SDWR & 532 & 1,145 & 1,540 & 14 & 14 \\
\hline 06332770 & 14 & 250 & SDWR & 464 & 628 & 949 & 14 & 14 \\
\hline 06337470 & 14 & 250 & SDWR & 447 & 818 & 1580 & 14 & 14 \\
\hline 06337480 & 14 & 250 & SDWR & 735 & 2,065 & 2,980 & 14 & 14 \\
\hline
\end{tabular}


Table 7. Summary statistics for selected water-quality constituents at surface-water sites on Fort Berthold Reservation, North Dakota, 2014-17.—Continued

[USGS, U.S. Geological Survey; EPA, U.S. Environmental Protection Agency; SDWR, secondary drinking water regulation; nd, nondetect; MCL, maximum contaminant level]

\begin{tabular}{|c|c|c|c|c|c|c|c|c|}
\hline $\begin{array}{l}\text { USGS station } \\
\text { number } \\
\text { (fig. 1) }\end{array}$ & $\begin{array}{c}\text { Number of } \\
\text { samples }\end{array}$ & $\begin{array}{c}\text { EPA } \\
\text { water-quality } \\
\text { standard } 1 \\
\end{array}$ & $\begin{array}{c}\text { EPA } \\
\text { water-quality } \\
\text { standard type } \\
\end{array}$ & Minimum & Median & Maximum & $\begin{array}{l}\text { Number of } \\
\text { detections }\end{array}$ & $\begin{array}{l}\text { Number of detections with a } \\
\text { concentration that exceeded } \\
\text { the water-quality standard }\end{array}$ \\
\hline \multicolumn{9}{|c|}{ Aluminum, dissolved (micrograms per liter as aluminum) } \\
\hline 06332515 & 14 & 50 & SDWR & 167 & 191 & 380 & 5 & 5 \\
\hline 06332520 & 14 & 50 & SDWR & 105 & 177 & 249 & 2 & 2 \\
\hline 06332523 & 14 & 50 & SDWR & nd & nd & nd & 0 & 0 \\
\hline 06332770 & 14 & 50 & SDWR & 116 & 116 & 116 & 1 & 1 \\
\hline 06337470 & 14 & 50 & SDWR & 103 & 216 & 527 & 6 & 6 \\
\hline 06337480 & 14 & 50 & SDWR & 154 & 173 & 337 & 3 & 3 \\
\hline \multicolumn{9}{|c|}{ Arsenic, dissolved (micrograms per liter as arsenic) } \\
\hline 06332515 & 14 & 10 & MCL & 1.8 & 2.7 & 4.3 & 8 & 0 \\
\hline 06332520 & 14 & 10 & MCL & 2.0 & 3.5 & 7.3 & 10 & 0 \\
\hline 06332523 & 14 & 10 & MCL & 2.2 & 5.0 & 6.0 & 11 & 0 \\
\hline 06332770 & 14 & 10 & MCL & 2.1 & 6.2 & 8.4 & 12 & 0 \\
\hline 06337470 & 14 & 10 & MCL & 1.8 & 2.0 & 2.4 & 8 & 0 \\
\hline 06337480 & 14 & 10 & MCL & 2.0 & 4.1 & 6.7 & 9 & 0 \\
\hline \multicolumn{9}{|c|}{ Iron, dissolved (micrograms per liter as iron) } \\
\hline 06332515 & 14 & 300 & SDWR & 102 & 145 & 349 & 6 & 1 \\
\hline 06332520 & 14 & 300 & SDWR & 138 & 210 & 297 & 5 & 0 \\
\hline 06332523 & 14 & 300 & SDWR & nd & nd & nd & 0 & 0 \\
\hline 06332770 & 14 & 300 & SDWR & 109 & 138 & 166 & 2 & 0 \\
\hline 06337470 & 14 & 300 & SDWR & 146 & 178 & 375 & 6 & 1 \\
\hline 06337480 & 14 & 300 & SDWR & 137 & 250 & 317 & 3 & 1 \\
\hline \multicolumn{9}{|c|}{ Manganese, dissolved (micrograms per liter as manganese) } \\
\hline 06332515 & 14 & 50 & SDWR & 3.2 & 21.8 & 75.3 & 14 & 4 \\
\hline 06332520 & 14 & 50 & SDWR & 22.3 & 46.7 & 115 & 14 & 6 \\
\hline 06332523 & 14 & 50 & SDWR & 15.9 & 49.3 & 112 & 14 & 7 \\
\hline 06332770 & 14 & 50 & SDWR & 3.3 & 47 & 114 & 14 & 6 \\
\hline 06337470 & 14 & 50 & SDWR & 2.4 & 20.9 & 147 & 13 & 2 \\
\hline 06337480 & 14 & 50 & SDWR & 45.7 & 122 & 191 & 14 & 13 \\
\hline
\end{tabular}


Table 7. Summary statistics for selected water-quality constituents at surface-water sites on Fort Berthold Reservation, North Dakota, 2014-17.-Continued [USGS, U.S. Geological Survey; EPA, U.S. Environmental Protection Agency; SDWR, secondary drinking water regulation; nd, nondetect; MCL, maximum contaminant level]

\begin{tabular}{|c|c|c|c|c|c|c|c|c|}
\hline $\begin{array}{l}\text { USGS station } \\
\text { number } \\
\text { (fig. 1) }\end{array}$ & $\begin{array}{l}\text { Number of } \\
\text { samples }\end{array}$ & $\begin{array}{c}\text { EPA } \\
\text { water-quality } \\
\text { standard1 }\end{array}$ & $\begin{array}{c}\text { EPA } \\
\text { water-quality } \\
\text { standard type }\end{array}$ & Minimum & Median & Maximum & $\begin{array}{l}\text { Number of } \\
\text { detections }\end{array}$ & $\begin{array}{l}\text { Number of detections with a } \\
\text { concentration that exceeded } \\
\text { the water-quality standard }\end{array}$ \\
\hline \multicolumn{9}{|c|}{ Ammonia, dissolved (milligrams per liter as nitrogen) } \\
\hline 06332515 & 14 & 30 & Taste threshold & 0.1 & 0.5 & 0.9 & 2 & 0 \\
\hline 06332520 & 14 & 30 & Taste threshold & 0.1 & 0.1 & 0.1 & 1 & 0 \\
\hline 06332523 & 14 & 30 & Taste threshold & 0.1 & 0.1 & 0.1 & 1 & 0 \\
\hline 06332770 & 14 & 30 & Taste threshold & 0.1 & 0.1 & 0.1 & 3 & 0 \\
\hline 06337470 & 14 & 30 & Taste threshold & nd & nd & nd & 0 & 0 \\
\hline 06337480 & 14 & 30 & Taste threshold & nd & nd & nd & 0 & 0 \\
\hline \multicolumn{9}{|c|}{ Nitrate, dissolved (milligrams per liter as nitrogen) } \\
\hline 06332515 & 5 & 10 & MCL & 0.016 & 0.016 & 0.016 & 1 & 0 \\
\hline 06332520 & 5 & 10 & MCL & 0.013 & 0.076 & 0.081 & 3 & 0 \\
\hline 06332523 & 5 & 10 & MCL & 0.182 & 0.182 & 0.182 & 1 & 0 \\
\hline 06332770 & 5 & 10 & $\mathrm{MCL}$ & 0.010 & 0.199 & 0.387 & 2 & 0 \\
\hline 06337470 & 5 & 10 & MCL & 0.019 & 0.268 & 0.517 & 2 & 0 \\
\hline 06337480 & 5 & 10 & MCL & nd & nd & nd & 0 & 0 \\
\hline \multicolumn{9}{|c|}{ Nitrite, dissolved (milligrams per liter as nitrogen) } \\
\hline 06332515 & 5 & 1 & MCL & 0.006 & 0.009 & 0.013 & 2 & 0 \\
\hline 06332520 & 5 & 1 & MCL & 0.005 & 0.008 & 0.011 & 2 & 0 \\
\hline 06332523 & 5 & 1 & MCL & 0.007 & 0.007 & 0.029 & 3 & 0 \\
\hline 06332770 & 5 & 1 & MCL & 0.006 & 0.009 & 0.012 & 2 & 0 \\
\hline 06337470 & 5 & 1 & MCL & 0.012 & 0.012 & 0.030 & 3 & 0 \\
\hline 06337480 & 5 & 1 & MCL & 0.006 & 0.007 & 0.008 & 2 & 0 \\
\hline
\end{tabular}

1U.S. Environmental Protection Agency, 2018. 
the EPA MCL of $10 \mathrm{mg} / \mathrm{L}$ (tables 5, 7). When detected, the median dissolved nitrate concentrations ranged from 0.016 to $0.268 \mathrm{mg} / \mathrm{L}$. Dissolved nitrite was detected in 14 samples at concentrations that were less than the EPA MCL of $1 \mathrm{mg} / \mathrm{L}$ (table 7). When detected, the median dissolved nitrite concentrations ranged from 0.007 to $0.012 \mathrm{mg} / \mathrm{L}$.

\section{Groundwater Quality}

Groundwater-quality data were collected from 34 wells on the reservation during 2014, 2015, and 2017 (table 2). The sampled wells completed in the Quaternary aquifer system (contained in Quaternary-age glacial and fluvial sediments in the reservation) consisted of 3 wells in the White Shield aquifer, 4 wells in the Sanish aquifer, 6 wells in the Shell Creek aquifer, 1 well in the New Town aquifer, and 1 well in the Tongue River aquifer. The sampled wells completed in the lower Tertiary aquifer system consisted of 13 wells in the Sentinel Butte aquifer (contained in the Sentinel Butte Member of the Fort Union Formation) and 1 well in the Fort Union aquifer (contained in the Fort Union Formation). The sampled wells completed in the Upper Cretaceous aquifer system consisted of 5 wells in the Fox Hills aquifer (contained in the Fox Hills Sandstone). These 34 wells included domestic, stock, monitoring, and industrial wells that represent the most utilized aquifer units and had good spatial coverage on the reservation. Most of these wells were in the western part of the reservation (fig. 1).

Summary statistics for the 11 selected constituents in groundwater in the 34 wells completed in the Quaternary, lower Tertiary, or Upper Cretaceous aquifer systems are summarized in table 8 . Summary statistics for all constituents analyzed in groundwater from the 34 wells are presented in table 1.5. The historical groundwater data predate the intensive energy development since the 2000s, and some of the data were collected in the 1950s. The most recent historical groundwater data for the wells on the reservation were prior to the early 1990s (Wald and Cates, 1995; Cates and MacekRowland, 1998). Summary statistics for these historical waterquality constituents in the major aquifers on the reservation are presented in table 2.1 (Cates and Macek-Rowland, 1998).

The major ions that were selected for additional discussion are dissolved chloride, dissolved solids, dissolved sodium, and dissolved sulfate. The only dissolved chloride concentration that exceeded the EPA SDWR of $250 \mathrm{mg} / \mathrm{L}$ was in a sample from a well completed in the Upper Cretaceous aquifer system (table 8; map number 34, fig. 3). The median dissolved chloride concentrations were 5.1, 2.6, and $237 \mathrm{mg} / \mathrm{L}$ in the Quaternary, lower Tertiary, and Upper Cretaceous aquifer systems, respectively. The Upper Cretaceous aquifer system had the highest dissolved chloride concentrations that ranged from 185 to $271 \mathrm{mg} / \mathrm{L}$. Dissolved solids concentrations exceeded the EPA SDWR of $500 \mathrm{mg} / \mathrm{L}$ in samples from 32 of 34 groundwater wells (table 8). The median dissolved solids concentrations were $1,710,1,460$, and $1,590 \mathrm{mg} / \mathrm{L}$ in the Quaternary, lower Tertiary, and Upper Cretaceous aquifer systems, respectively. The median dissolved solids concentrations were more than double the EPA SDWR of $500 \mathrm{mg} / \mathrm{L}$ (tables 5, 8). The dissolved solids concentrations that exceeded the EPA SDWR of $500 \mathrm{mg} / \mathrm{L}$ were spatially distributed throughout the reservation and included all the major aquifer systems (fig. 4). Dissolved sodium concentrations exceeded the EPA taste threshold of $30 \mathrm{mg} / \mathrm{L}$ in samples from all groundwater wells (table 8). The median dissolved sodium concentrations were 513,281 , and $587 \mathrm{mg} / \mathrm{L}$ in the Quaternary, lower Tertiary, and Upper Cretaceous aquifer systems, respectively (table 8). The dissolved sodium concentrations that exceeded the EPA taste threshold of $30 \mathrm{mg} / \mathrm{L}$ were spatially distributed throughout the reservation and included all the major aquifer systems (fig. 5). Dissolved sulfate concentrations exceeded the EPA SDWR of $250 \mathrm{mg} / \mathrm{L}$ in samples from 21 of 35 groundwater wells (table 8). When detected, the median dissolved sulfate concentrations were 568 and $302 \mathrm{mg} / \mathrm{L}$ in the Quaternary and lower Tertiary aquifer systems, respectively. Dissolved sulfate concentrations were reported as nondetects in the Upper Cretaceous aquifer system (table 8). The highest dissolved sulfate concentrations that exceeded the EPA SDWR of $250 \mathrm{mg} / \mathrm{L}$ were in the Quaternary and lower Tertiary aquifer systems and had dissolved sulfate concentrations of 2,300 and 2,310 mg/L, respectively (table 8 , fig. 6). The groundwater well (map number 3, fig. 6) in the Quaternary aquifer system was sampled in 2014 and 2017, respectively.

Trace metals that were selected for discussion are dissolved aluminum, dissolved arsenic, dissolved iron, and dissolved manganese. All dissolved aluminum concentrations were reported as less than $100 \mu \mathrm{g} / \mathrm{L}$, except for one sample collected from a well in the lower Tertiary aquifer system, with a concentration of $137 \mu \mathrm{g} / \mathrm{L}$. Dissolved arsenic concentrations exceeded the EPA MCL of $10 \mu \mathrm{g} / \mathrm{L}$ in samples from 7 of 35 groundwater wells (table 8). When detected, the median dissolved arsenic concentrations were 8.9 and $3.5 \mu \mathrm{g} / \mathrm{L}$ in the Quaternary and Upper Cretaceous aquifer systems, respectively. Dissolved arsenic concentrations were reported as nondetects in the lower Tertiary aquifer system (table 8). The seven groundwater wells that exceeded the EPA MCL of $10 \mu \mathrm{g} / \mathrm{L}$ generally were on the northern and eastern side of the reservation from monitoring wells in the Quaternary aquifer system (fig. 7). Dissolved iron concentrations exceeded the EPA SDWR of $300 \mu \mathrm{g} / \mathrm{L}$ in samples from 17 of 35 groundwater wells (table 8). When detected, the median dissolved iron concentrations were 1,220 and $230 \mu \mathrm{g} / \mathrm{L}$ in the Quaternary and lower Tertiary aquifer systems, respectively. Dissolved iron concentrations were reported as nondetects in the Upper Cretaceous aquifer system (table 8). The dissolved iron concentrations that exceeded the EPA SDWR of $300 \mu \mathrm{g} / \mathrm{L}$ were from wells in the Quaternary and lower Tertiary aquifer systems (fig. 8). Dissolved manganese concentrations exceeded the EPA SDWR of $50 \mu \mathrm{g} / \mathrm{L}$ in samples from 14 of 35 groundwater wells (table 8 ). When detected, the median dissolved manganese concentrations were $104,46.8$, and $3.0 \mu \mathrm{g} / \mathrm{L}$ 
in the Quaternary, lower Tertiary, and Upper Cretaceous aquifer systems, respectively (table 8). The dissolved manganese concentrations that exceeded the EPA SDWR of $50 \mu \mathrm{g} / \mathrm{L}$ were from wells in the Quaternary and lower Tertiary aquifer systems (fig. 9).

Nutrients that were selected for discussion include dissolved ammonia, dissolved nitrate, and dissolved nitrite. None of the nutrient concentrations exceeded any water-quality standards. Dissolved ammonia was detected in 30 samples at concentrations that were less than the EPA taste threshold of $30 \mathrm{mg} / \mathrm{L}$ (table 8). When detected, the median dissolved ammonia concentrations were $0.6,0.2$, and $0.6 \mathrm{mg} / \mathrm{L}$ in the Quaternary, lower Tertiary, and Upper Cretaceous aquifer systems, respectively (table 8). Dissolved ammonia concentrations were detected in samples from wells in each of the aquifer systems (fig. 10). Nitrate was detected in only one sample, and nitrite was not detected in any samples. All dissolved nitrate and dissolved nitrite concentrations were less than the EPA MCL of 10 and $1 \mathrm{mg} / \mathrm{L}$, respectively (table 8). 
Table 8. Summary statistics for selected water-quality constituents in groundwater wells on Fort Berthold Reservation, North Dakota, $2014-17$.

[EPA, U.S. Environmental Protection Agency; Cl, chloride; SDWR, secondary drinking water regulation; Na, sodium; $\mathrm{SO}_{4}$, sulfate; $\mathrm{Al}$, aluminum; nd, nondetect; As, arsenic; $\mathrm{MCL}$, maximum contaminant level; Fe, iron; Mn, manganese]

\begin{tabular}{|c|c|c|c|c|c|c|c|c|}
\hline Constituent & $\begin{array}{c}\text { EPA } \\
\text { water-quality } \\
\text { standard }\end{array}$ & $\begin{array}{c}\text { EPA } \\
\text { water-quality } \\
\text { standard type }\end{array}$ & $\begin{array}{l}\text { Number } \\
\text { of } \\
\text { samples }\end{array}$ & Minimum & Median & Maximum & $\begin{array}{c}\text { Number } \\
\text { of } \\
\text { detections }\end{array}$ & $\begin{array}{c}\text { Number of } \\
\text { detections } \\
\text { with a } \\
\text { concentration } \\
\text { that exceeded } \\
\text { the water- } \\
\text { quality standard }\end{array}$ \\
\hline \multicolumn{9}{|c|}{ Quaternary aquifer system } \\
\hline Chloride, dissolved (milligrams per liter as $\mathrm{Cl}$ ) & 250 & SDWR & 16 & 1.1 & 5.1 & 164 & 16 & 0 \\
\hline $\begin{array}{l}\text { Dissolved solids, residue on evaporation at } 180 \text { degrees } \\
\text { Celsius (milligrams per liter) }\end{array}$ & 500 & SDWR & 15 & 777 & 1.710 & 2.980 & 15 & 15 \\
\hline Sodium, dissolved (milligrams per liter as $\mathrm{Na}$ ) & 30 & Taste threshold & 16 & 132 & 513 & 892 & 16 & 16 \\
\hline Sulfate, dissolved (milligrams per liter as $\mathrm{SO}_{4}$ ) & 250 & SDWR & 16 & 181 & 568 & 2,300 & 15 & 13 \\
\hline Aluminum, dissolved (micrograms per liter as $\mathrm{Al}$ ) & 50 & SDWR & 16 & nd & nd & nd & 0 & 0 \\
\hline Arsenic, dissolved (micrograms per liter as As) & 10 & MCL & 16 & 2.5 & 8.9 & 30.1 & 15 & 7 \\
\hline Iron, dissolved (micrograms per liter as Fe) & 300 & SDWR & 16 & 355 & 1,220 & 7,080 & 15 & 15 \\
\hline Manganese, dissolved (micrograms per liter as Mn) & 50 & SDWR & 16 & 11 & 104 & 910 & 16 & 13 \\
\hline Ammonia, dissolved (milligrams per liter as nitrogen) & 30 & Taste threshold & 16 & 0.2 & 0.6 & 1.4 & 15 & 0 \\
\hline Nitrate, dissolved (milligrams per liter as nitrogen) & 10 & MCL & 10 & 0.006 & 0.006 & 0.006 & 1 & 0 \\
\hline Nitrite, dissolved (milligrams per liter as nitrogen) & 1 & MCL & 10 & nd & nd & nd & 0 & 0 \\
\hline \multicolumn{9}{|c|}{ Lower Tertiary aquifer system } \\
\hline Chloride, dissolved (milligrams per liter as $\mathrm{Cl}$ ) & 250 & SDWR & 14 & 0.9 & 2.6 & 24.7 & 14 & 0 \\
\hline $\begin{array}{l}\text { Dissolved solids, residue on evaporation at } 180 \text { degrees } \\
\text { Celsius (milligrams per liter) }\end{array}$ & 500 & SDWR & 14 & 373 & 1,460 & 4,100 & 14 & 12 \\
\hline Sodium, dissolved (milligrams per liter as $\mathrm{Na}$ ) & 30 & Taste threshold & 14 & 61.2 & 281 & 1,660 & 14 & 14 \\
\hline Sulfate, dissolved (milligrams per liter as $\mathrm{SO}_{4}$ ) & 250 & SDWR & 14 & 41 & 302 & 2,310 & 14 & 8 \\
\hline Aluminum, dissolved (micrograms per liter as $\mathrm{Al}$ ) & 50 & SDWR & 14 & 137 & 137 & 137 & 1 & 1 \\
\hline Arsenic, dissolved (micrograms per liter as As) & 10 & MCL & 14 & nd & nd & nd & 0 & 0 \\
\hline Iron, dissolved (micrograms per liter as Fe) & 300 & SDWR & 14 & 104 & 230 & 5,080 & 5 & 2 \\
\hline Manganese, dissolved (micrograms per liter as Mn) & 50 & SDWR & 14 & 3.2 & 46.8 & 5,530 & 11 & 1 \\
\hline Ammonia, dissolved (milligrams per liter as nitrogen) & 30 & Taste threshold & 14 & 0.1 & 0.2 & 0.7 & 10 & 0 \\
\hline Nitrate, dissolved (milligrams per liter as nitrogen) & 10 & MCL & 2 & nd & nd & nd & 0 & 0 \\
\hline Nitrite, dissolved (milligrams per liter as nitrogen) & 1 & MCL & 2 & nd & nd & nd & 0 & 0 \\
\hline
\end{tabular}


Table 8. Summary statistics for selected water-quality constituents in groundwater wells on Fort Berthold Reservation, North Dakota, 2014-17.-Continued

[EPA, U.S. Environmental Protection Agency; Cl, chloride; SDWR, secondary drinking water regulation; Na, sodium; $\mathrm{SO}_{4}$, sulfate; $\mathrm{Al}$, aluminum; nd, nondetect; As, arsenic; $\mathrm{MCL}$, maximum contaminant level; Fe, iron; Mn, manganese]

\begin{tabular}{|c|c|c|c|c|c|c|c|c|}
\hline Constituent & $\begin{array}{c}\text { EPA } \\
\text { water- } \\
\text { quality } \\
\text { standard }\end{array}$ & $\begin{array}{c}\text { EPA } \\
\text { water-quality } \\
\text { standard type }\end{array}$ & $\begin{array}{c}\text { Number } \\
\text { of } \\
\text { samples }\end{array}$ & Minimum & Median & Maximum & $\begin{array}{c}\text { Number } \\
\text { of } \\
\text { detections }\end{array}$ & $\begin{array}{l}\text { Number of } \\
\text { detections } \\
\text { with a } \\
\text { concentration } \\
\text { that exceeded } \\
\text { the water- } \\
\text { quality standard }\end{array}$ \\
\hline \multicolumn{9}{|c|}{ Upper Cretaceous aquifer system } \\
\hline Chloride, dissolved (milligrams per liter as $\mathrm{Cl}$ ) & 250 & SDWR & 5 & 185 & 237 & 271 & 5 & 1 \\
\hline $\begin{array}{l}\text { Dissolved solids, residue on evaporation at } 180 \text { degrees } \\
\text { Celsius (milligrams per liter) }\end{array}$ & 500 & SDWR & 5 & 1,470 & 1,590 & 1,750 & 5 & 5 \\
\hline Sodium, dissolved (milligrams per liter as $\mathrm{Na}$ ) & 30 & Taste threshold & 5 & 569 & 587 & 636 & 5 & 5 \\
\hline Sulfate, dissolved (milligrams per liter as $\mathrm{SO}_{4}$ ) & 250 & SDWR & 5 & nd & nd & nd & 0 & 0 \\
\hline Aluminum, dissolved (micrograms per liter as $\mathrm{Al}$ ) & 50 & SDWR & 5 & nd & nd & nd & 0 & 0 \\
\hline Arsenic, dissolved (micrograms per liter as As) & 10 & MCL & 5 & 2.8 & 3.5 & 4.1 & 4 & 0 \\
\hline Iron, dissolved (micrograms per liter as $\mathrm{Fe}$ ) & 300 & SDWR & 5 & nd & nd & nd & 0 & 0 \\
\hline Manganese, dissolved (micrograms per liter as Mn) & 50 & SDWR & 5 & 3.0 & 3.0 & 3.0 & 1 & 0 \\
\hline Ammonia, dissolved (milligrams per liter as nitrogen) & 30 & Taste threshold & 5 & 0.6 & 0.6 & 0.7 & 5 & 0 \\
\hline Nitrate, dissolved (milligrams per liter as nitrogen) & 10 & $\mathrm{MCL}$ & 2 & nd & nd & nd & 0 & 0 \\
\hline Nitrite, dissolved (milligrams per liter as nitrogen) & 1 & MCL & 2 & nd & nd & nd & 0 & 0 \\
\hline
\end{tabular}

1U.S. Environmental Protection Agency, 2018. 


\section{A. Quaternary aquifer system}

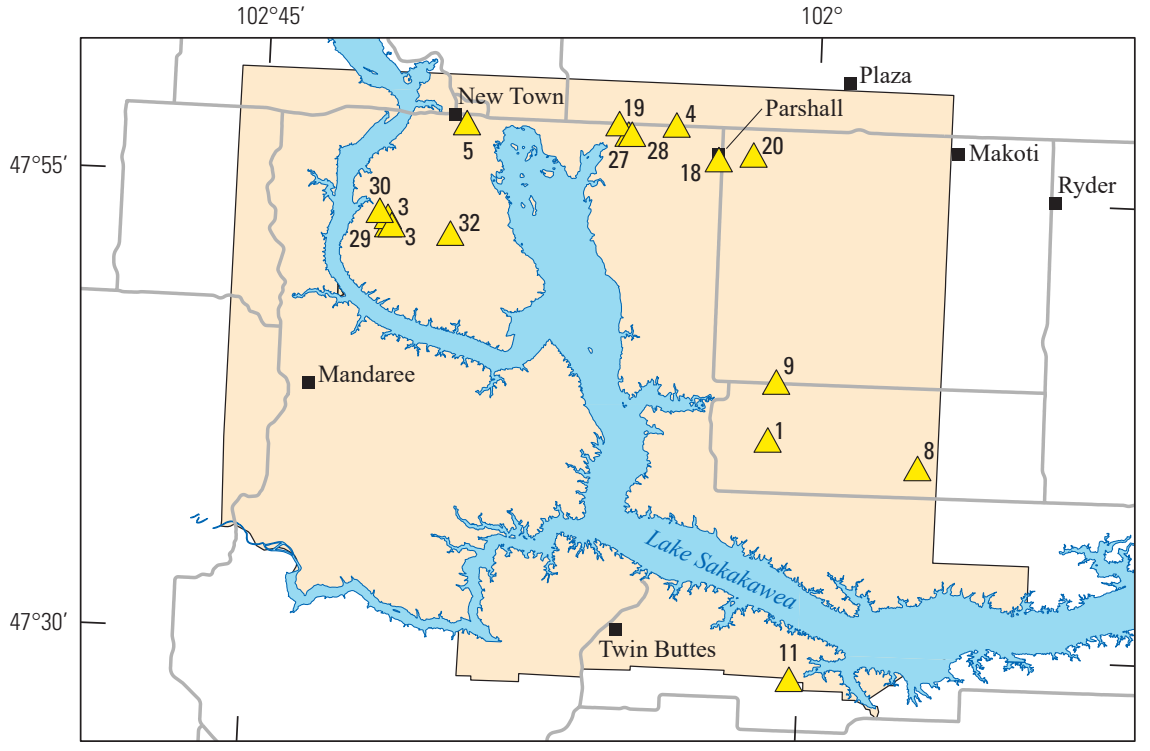

Base layers from North Dakota Geographic Information Systems (GIS) Hub Data Portal, 2018 Universal Transverse Mercator projection, zone $14 \mathrm{~N}$ North American Datum of 1983

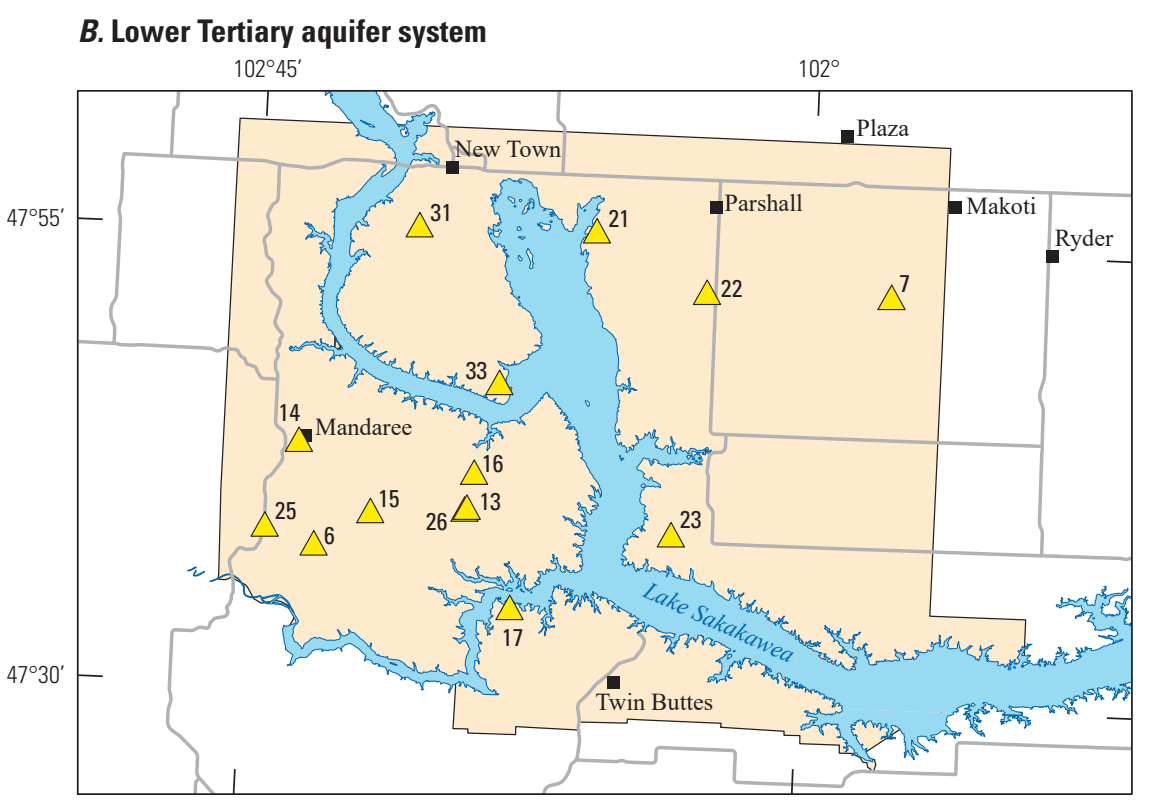

\section{Upper Cretaceous aquifer system}

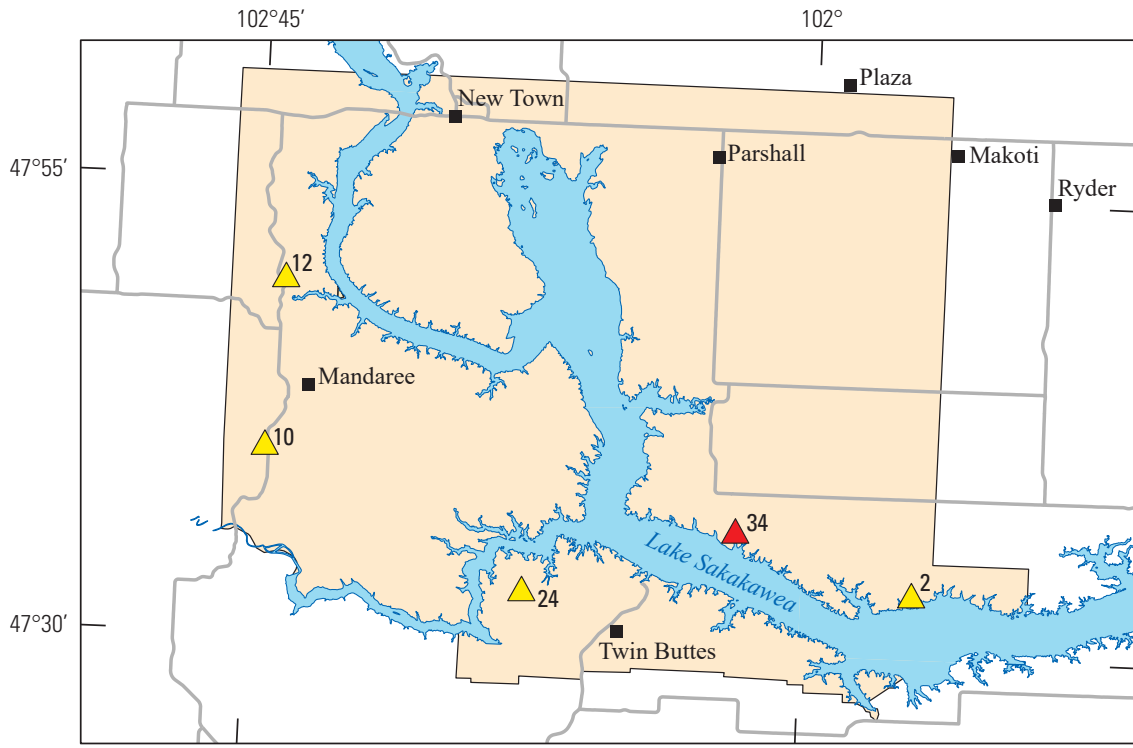

Figure 3. Spatial distribution of dissolved chloride concentrations, in milligrams per liter, for groundwater wells on Fort Berthold Reservation, North Dakota, 2014-17. $A$, Quaternary aquifer system; $B$, lower Tertiary aquifer system; and $C$, Upper Cretaceous aquifer system.

\section{EXPLANATION \\ $\square$ Fort Berthold Reservation \\ Chloride, dissolved (milligrams per liter as chloride), with map \\ $\triangle \quad$ Less than 0.2 (not detected) \\ $\triangle \quad 0.2$ to 250 \\ $\triangle$ Greater than 250}




\section{A. Ouaternary aquifer system}

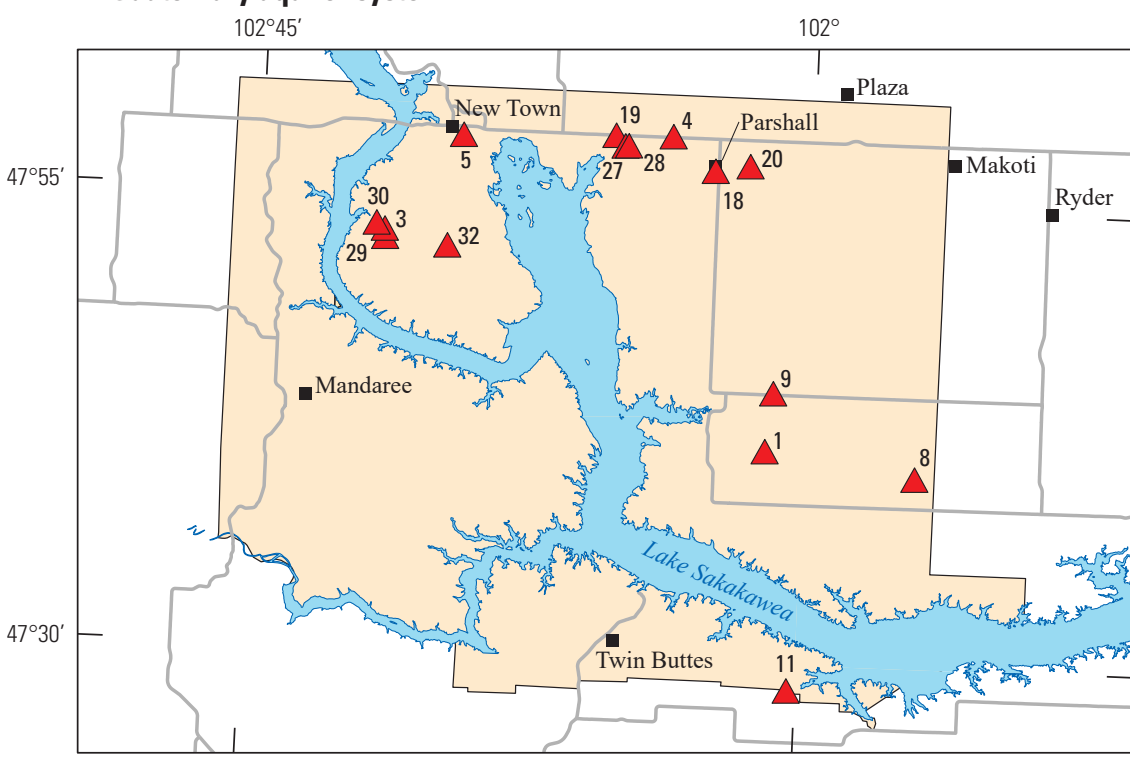

Base layers from North Dakota Geographic Information Systems (GIS) Hub Data Portal, 2018

Universal Transverse Mercator projection, zone $14 \mathrm{~N}$ North American Datum of 1983

\section{$B$. Lower Tertiary aquifer system}

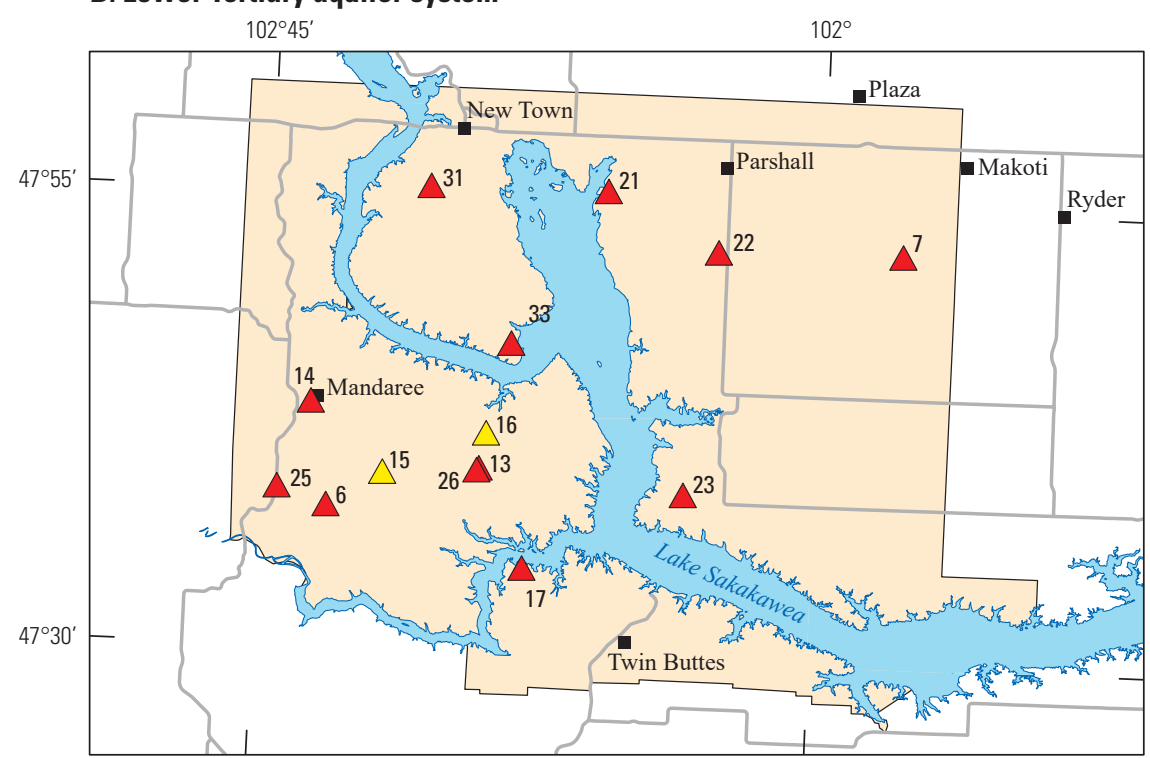

C. Upper Cretaceous aquifer system

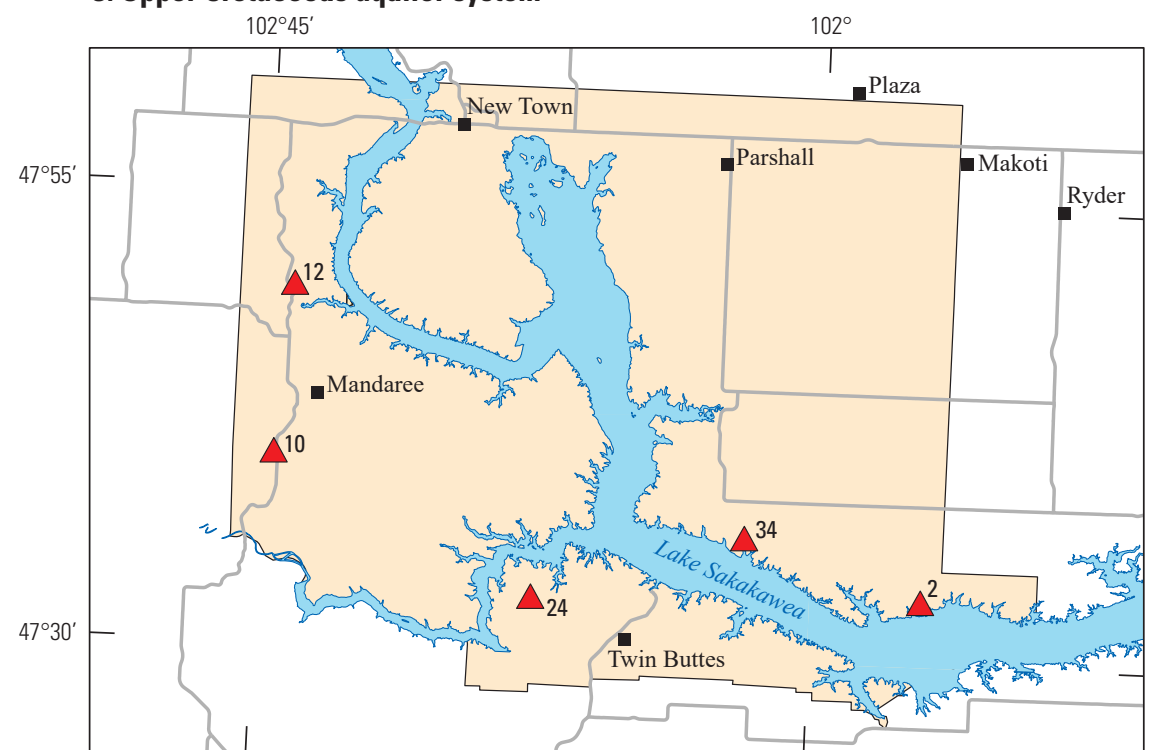

Figure 4. Spatial distribution of dissolved solids concentrations, in milligrams per liter, for groundwater wells on Fort Berthold Reservation, North Dakota, 2014-17.

$A$, Quaternary aquifer system; $B$, lower Tertiary aquifer system; and $C$, Upper Cretaceous aquifer system. 
A. Quaternary aquifer system

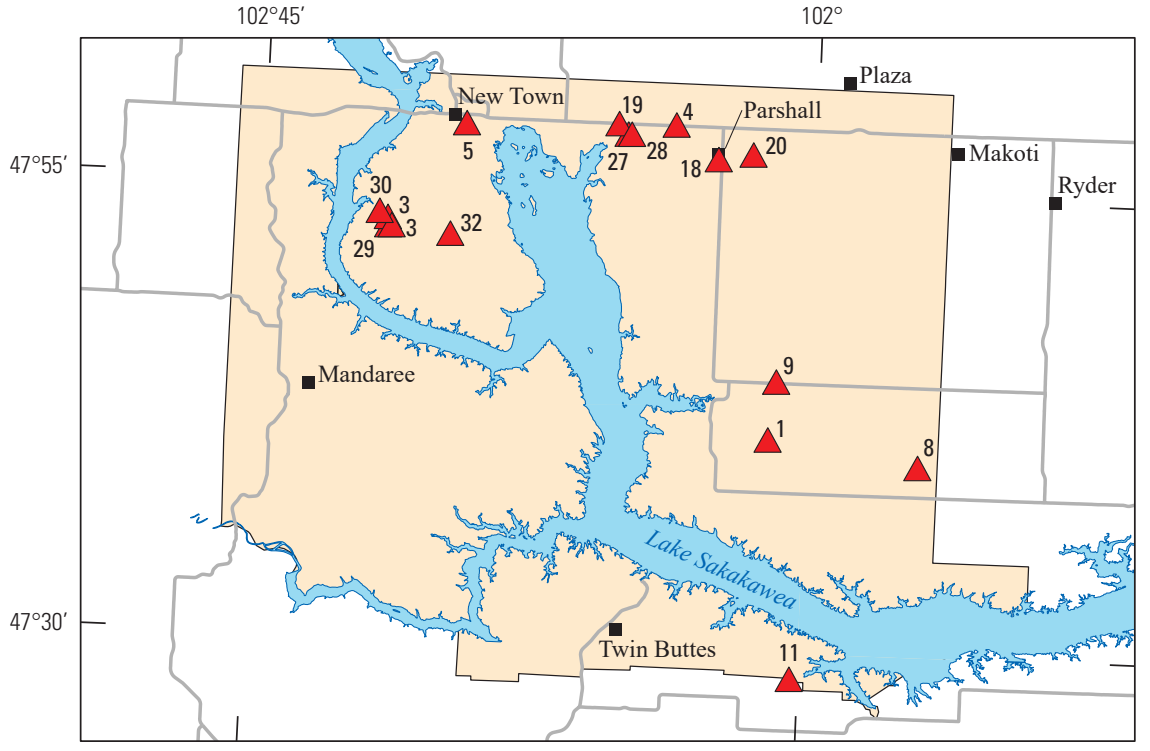

Base layers from North Dakota Geographic Information Systems (GIS) Hub Data Portal, 2018

Universal Transverse Mercator projection, zone $14 \mathrm{~N}$ North American Datum of 1983
B. Lower Tertiary aquifer system

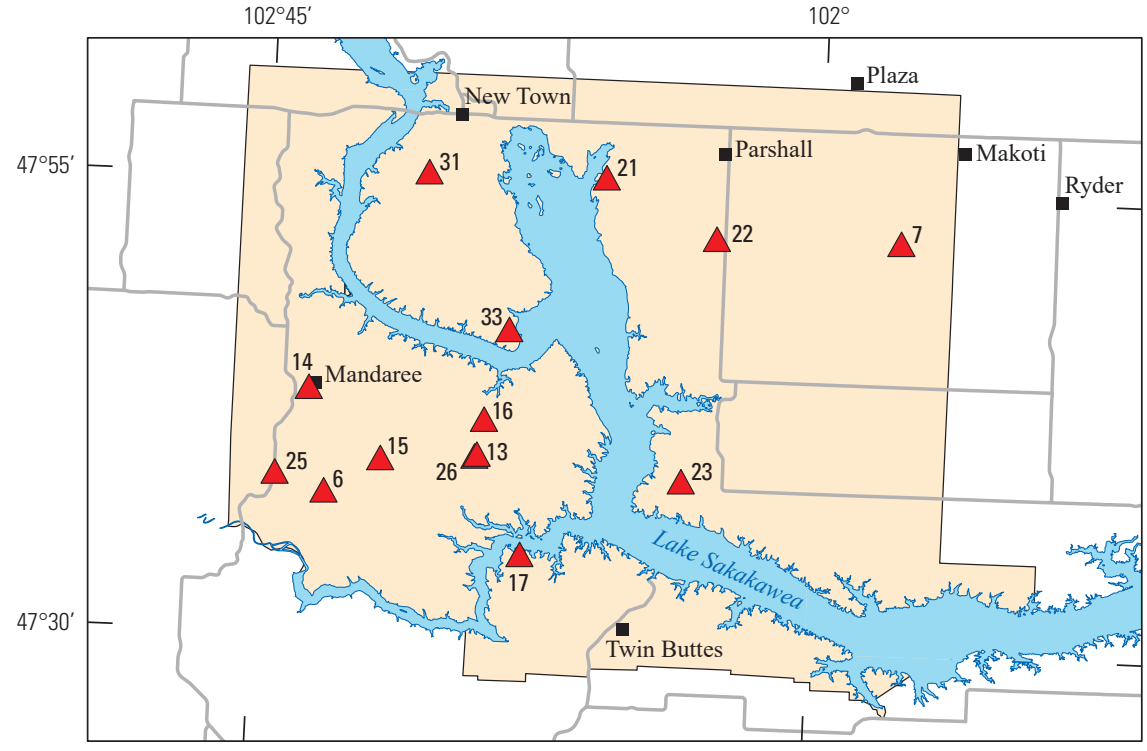

\section{Upper Cretaceous aquifer system}

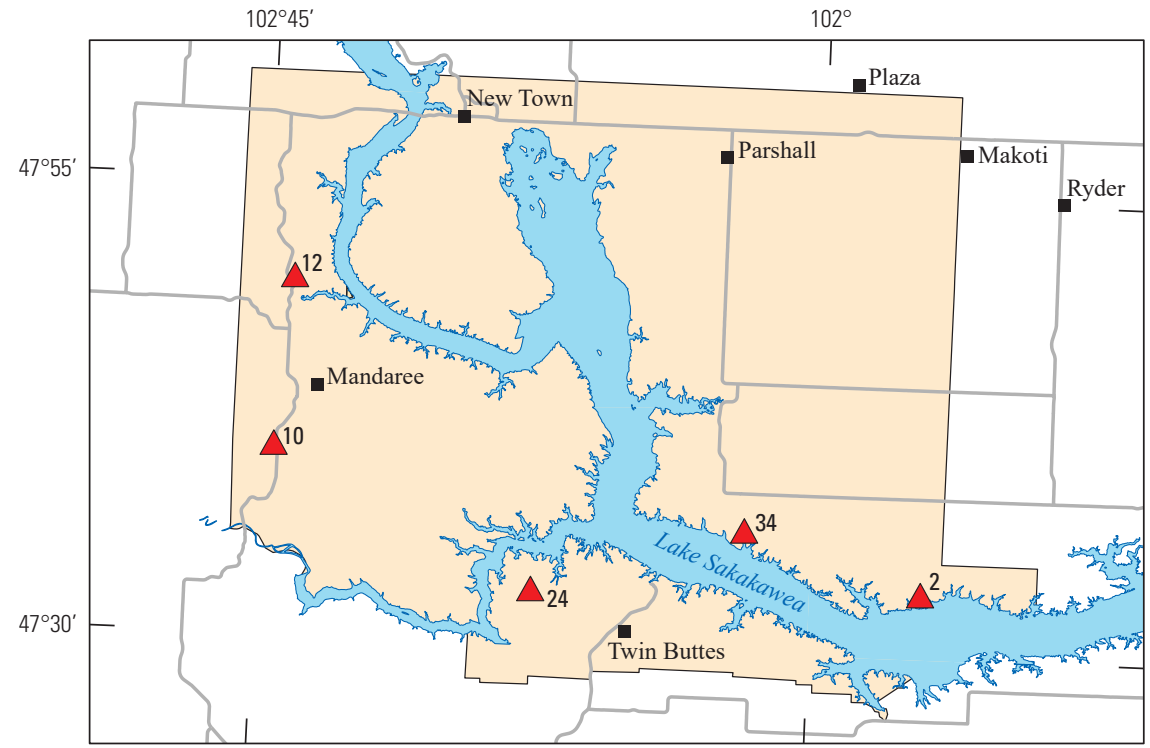

Figure 5. Spatial distribution of dissolved sodium concentrations, in milligrams per liter, for groundwater wells on Fort Berthold Reservation, North Dakota, 2014-17. $A$, Quaternary aquifer system; $B$, lower Tertiary aquifer system; and $C$, Upper Cretaceous aquifer system.

EXPLANATION
Fort Berthold Reservation
odium, dissolved (milligrams
per liter as sodium), with map
number (table 2)
$\begin{aligned} & \text { Less than } 0.5 \text { (not detected) } \\ & 0.5 \text { to } 30 \text { (not detected) } \\ & \text { Greater than } 30\end{aligned}$




\section{A. Ouaternary aquifer system}

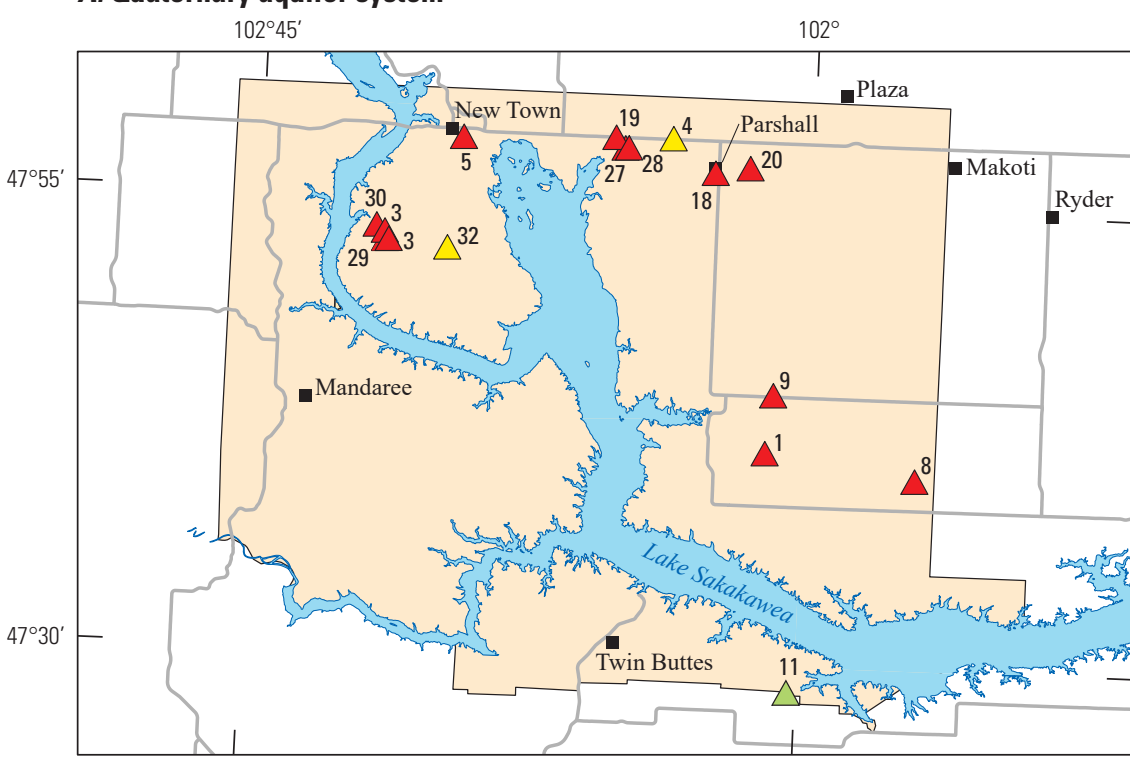

Base layers from North Dakota Geographic Information Systems (GIS) Hub Data Portal, 2018

Universal Transverse Mercator projection, zone $14 \mathrm{~N}$ North American Datum of 1983

\section{$B$. Lower Tertiary aquifer system}

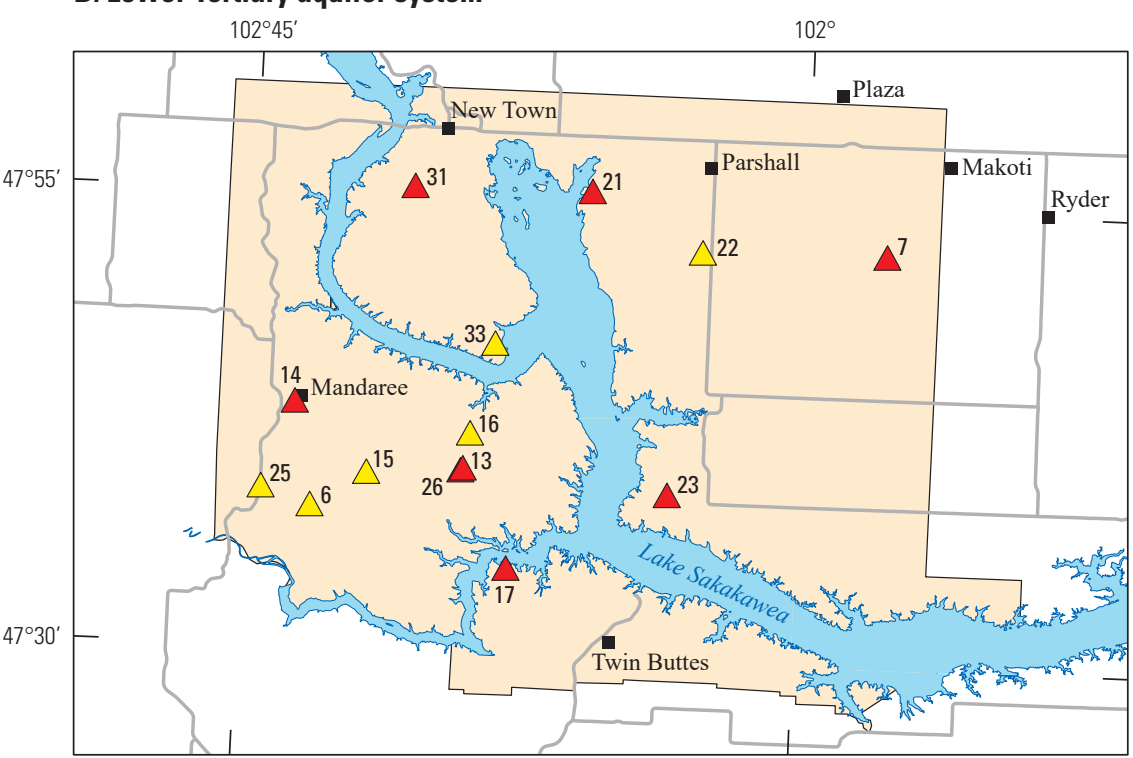

C. Upper Cretaceous aquifer system

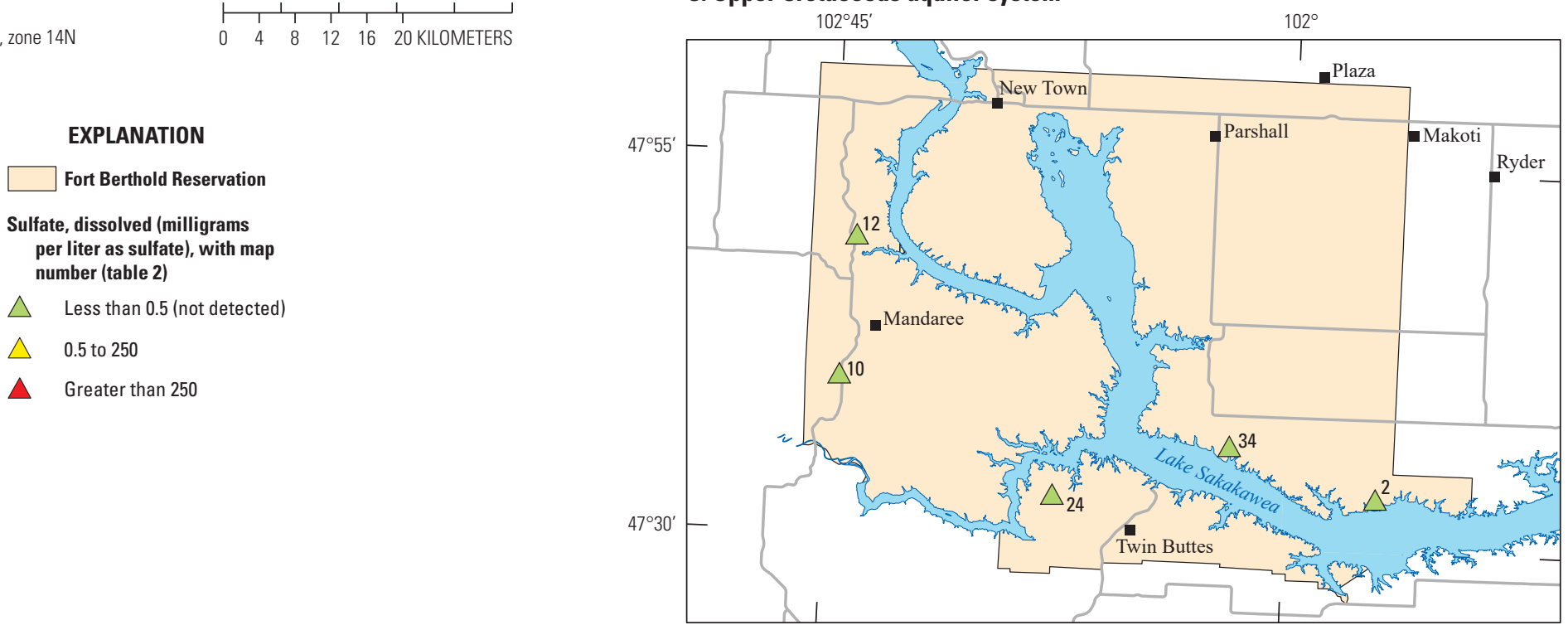

Figure 6. Spatial distribution of dissolved sulfate concentrations, in milligrams per liter, for groundwater wells on Fort Berthold Reservation, North Dakota, 2014-17.

$A$, Quaternary aquifer system; $B$, lower Tertiary aquifer system; and $C$, Upper Cretaceous aquifer system. 


\section{A. Quaternary aquifer system}

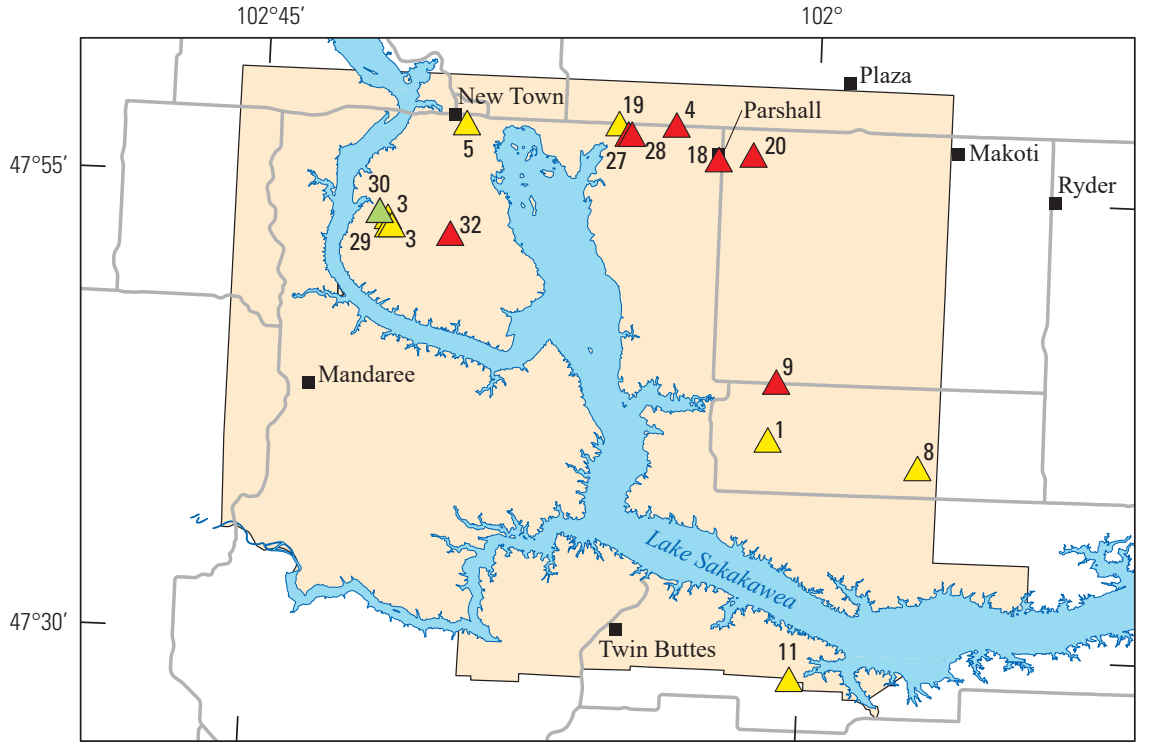

Base layers from North Dakota Geographic Information Systems (GIS) Hub Data Portal, 2018

Universal Transverse Mercator projection, zone 14N North American Datum of 1983

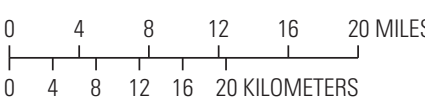

\section{B. Lower Tertiary aquifer system}

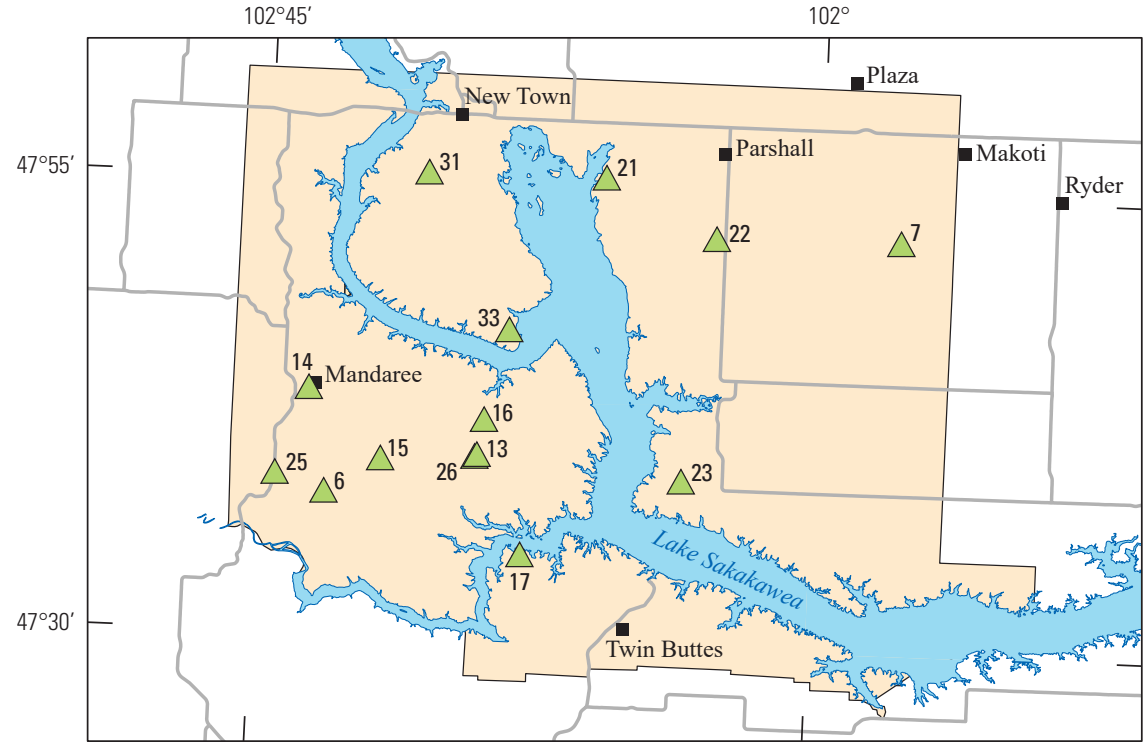

\section{Upper Cretaceous aquifer system}

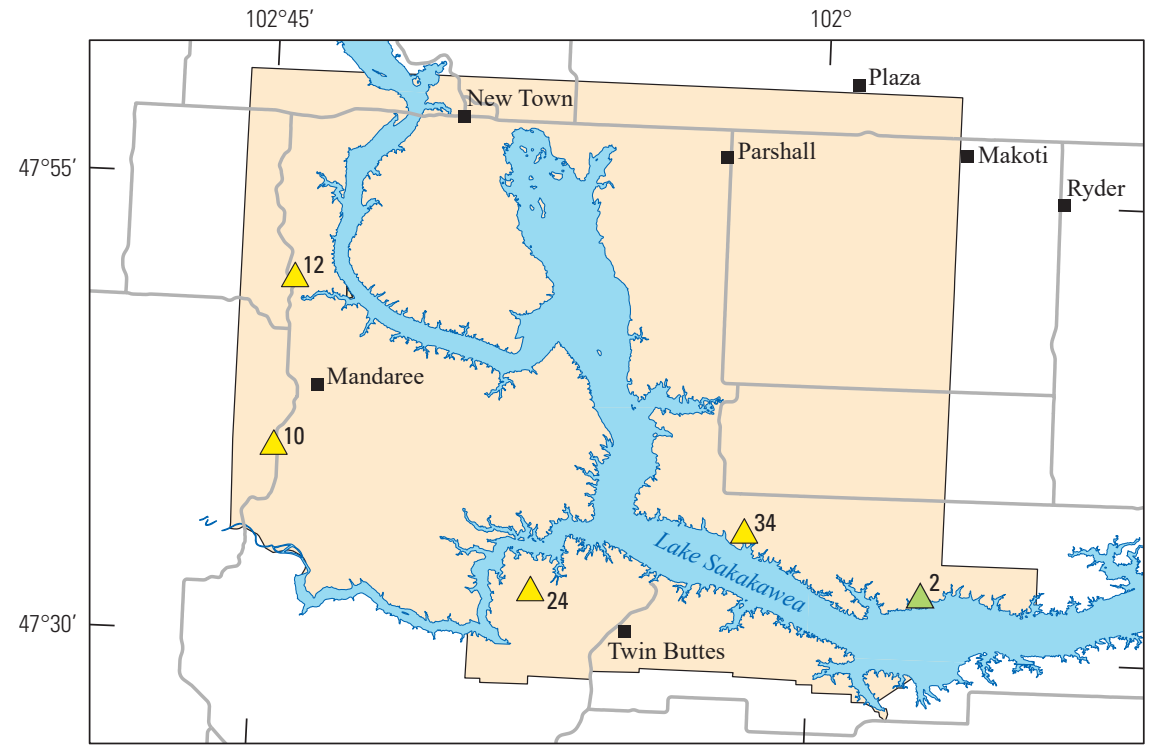

Figure 7. Spatial distribution of dissolved arsenic concentrations, in micrograms per liter, for groundwater wells on Fort Berthold Reservation, North Dakota, $2014-17$. $A$, Quaternary aquifer system; $B$, lower Tertiary aquifer system; and $C$, Upper Cretaceous aquifer system.

\section{EXPLANATION}

\section{$\square$ Fort Berthold Reservation}

Arsenic, dissolved (micrograms per liter as arsenic)

$\triangle \quad$ Less than 2 (not detected)

$\triangle 2$ to 10

$\triangle$ Greater than 10 


\section{A. Ouaternary aquifer system}

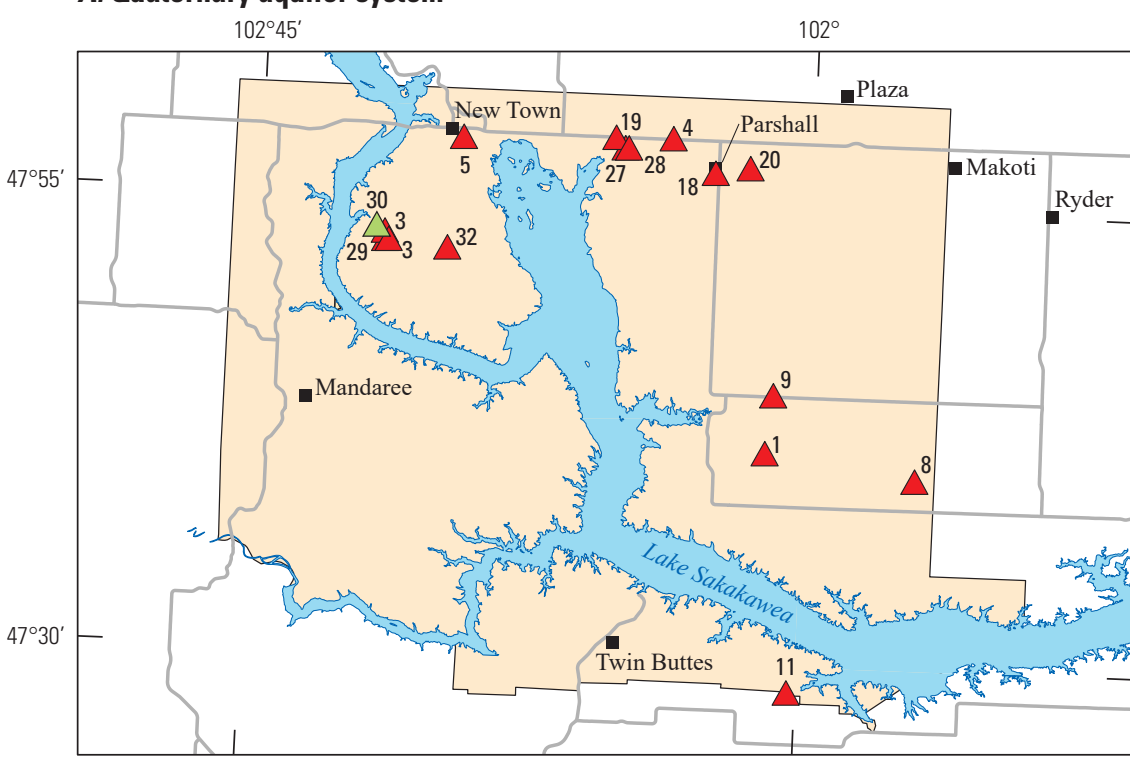

Base layers from North Dakota Geographic Information Systems (GIS) Hub Data Portal, 2018

Universal Transverse Mercator projection, zone 14N North American Datum of 1983

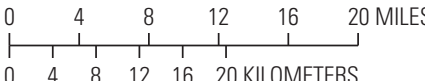

$\begin{array}{llllll}0 & 8 & 12 & 16 & 20 & \text { KLOMETERS }\end{array}$

\section{$B$. Lower Tertiary aquifer system}

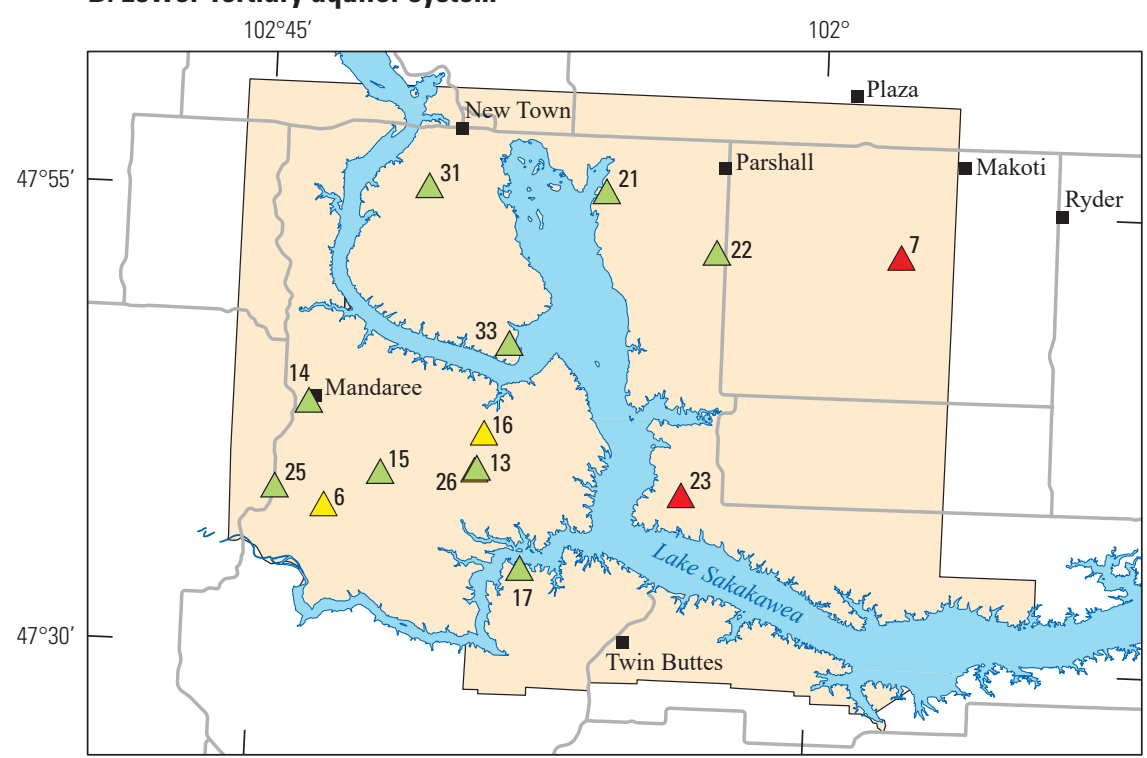

C. Upper Cretaceous aquifer system

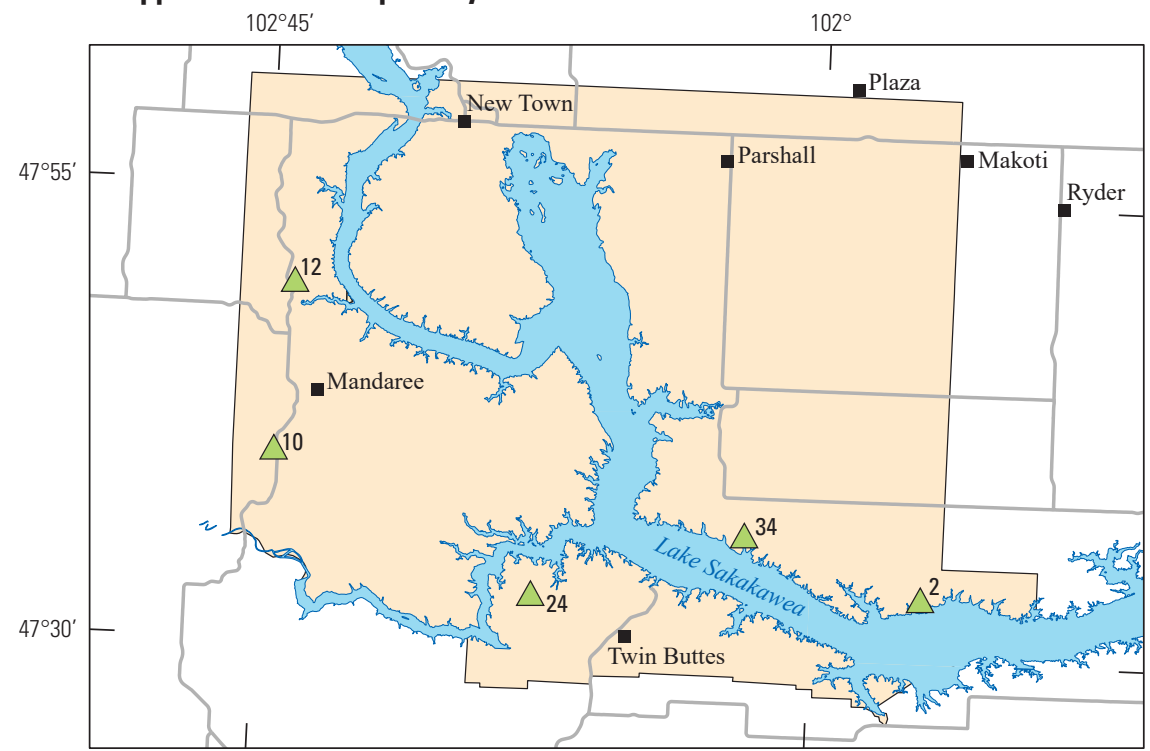

Figure 8. Spatial distribution of dissolved iron concentrations, in micrograms per liter, for groundwater wells on Fort Berthold Reservation, North Dakota, 2014-17. $A$, Quaternary aquifer system; $B$, lower Tertiary aquifer system; and $C$, Upper Cretaceous aquifer system.

\section{EXPLANATION}

\section{Fort Berthold Reservation}

Iron, dissolved (micrograms

per liter as iron), with map

$\triangle \quad$ Less than 100 (not detected)

$\triangle \quad 100$ to 300

$\triangle$ Greater than 300 


\section{A. Quaternary aquifer system}

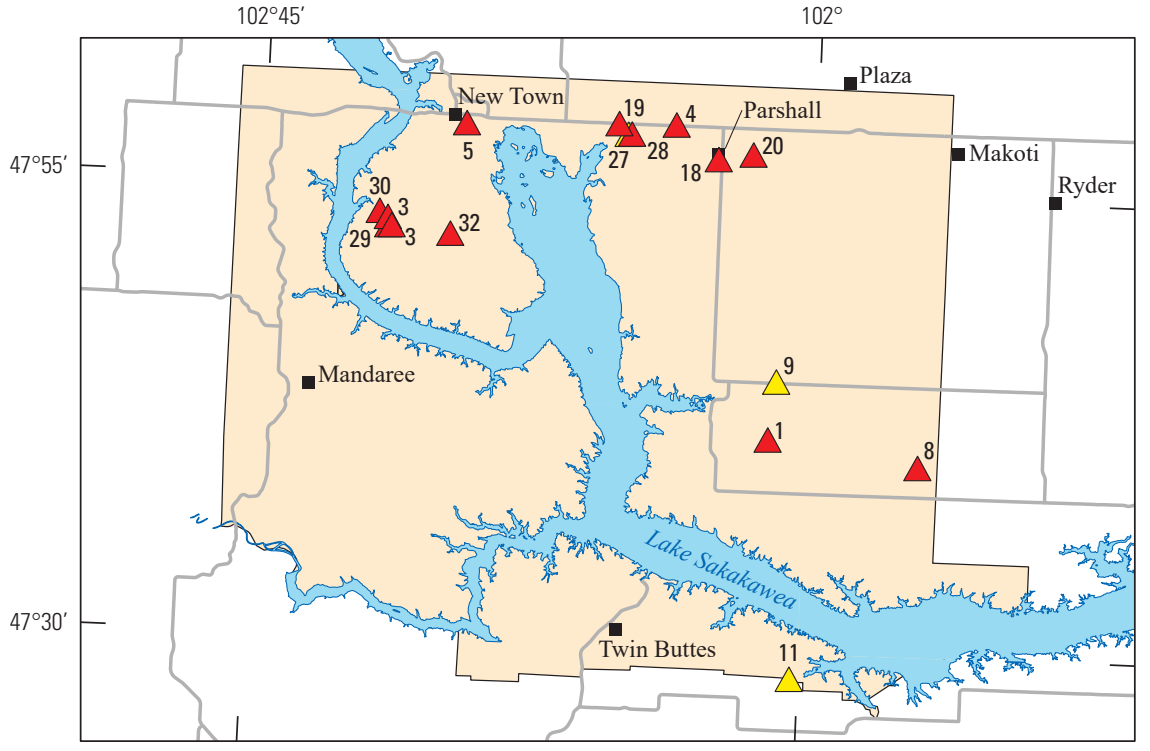

Base layers from North Dakota Geographic Information Systems (GIS) Hub Data Portal, 2018

Universal Transverse Mercator projection, zone $14 \mathrm{~N}$ North American Datum of 1983
B. Lower Tertiary aquifer system

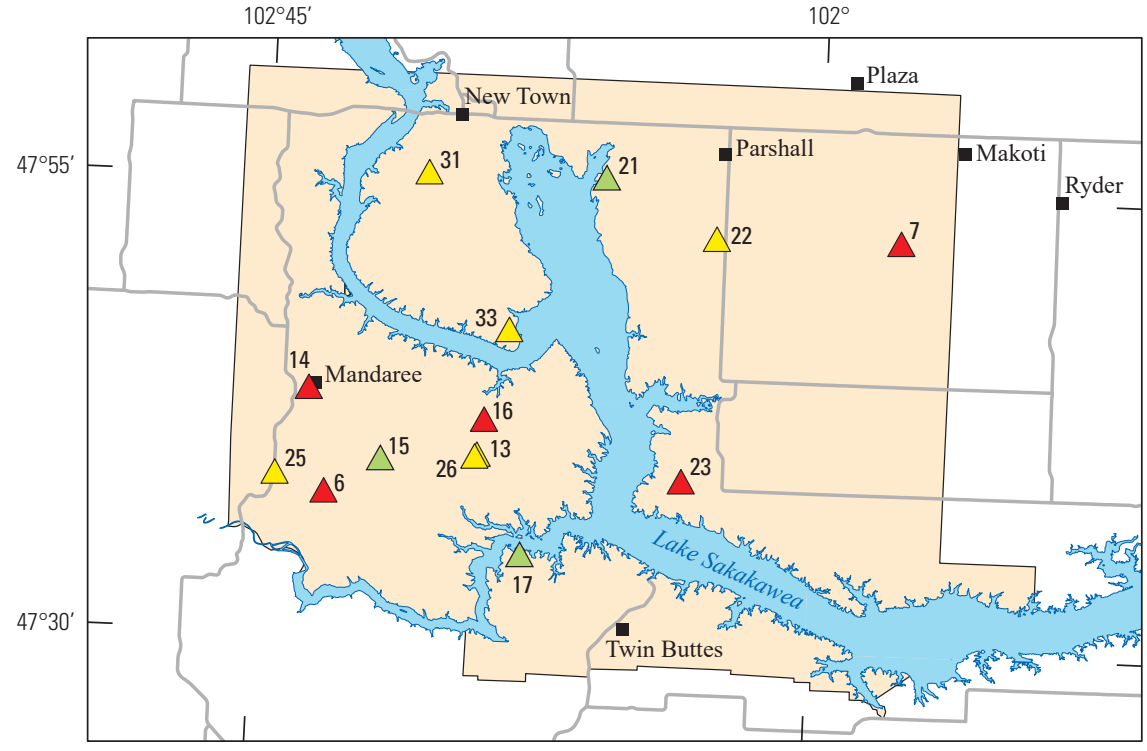

\section{Upper Cretaceous aquifer system}

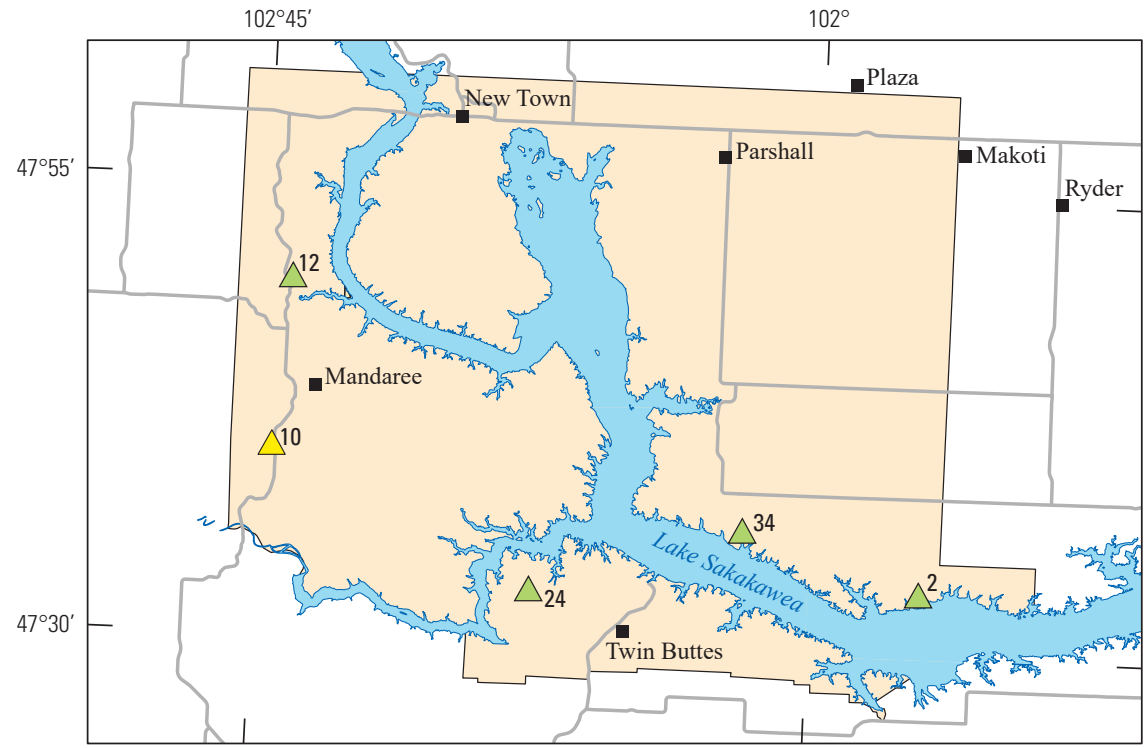

Figure 9. Spatial distribution of dissolved manganese concentrations, in micrograms per liter, for groundwater wells on Fort Berthold Reservation, North Dakota, $2014-17$. $A$, Quaternary aquifer system; $B$, lower Tertiary aquifer system; and $C$, Upper Cretaceous aquifer system.

\section{EXPLANATION}

\section{$\square$ Fort Berthold Reservation}

Manganese, dissolved (micrograms

per liter as manganese), with map

number (table 2)

$\triangle \quad 2$ to 50

$\triangle$ Greater than 50 


\section{A. Ouaternary aquifer system}

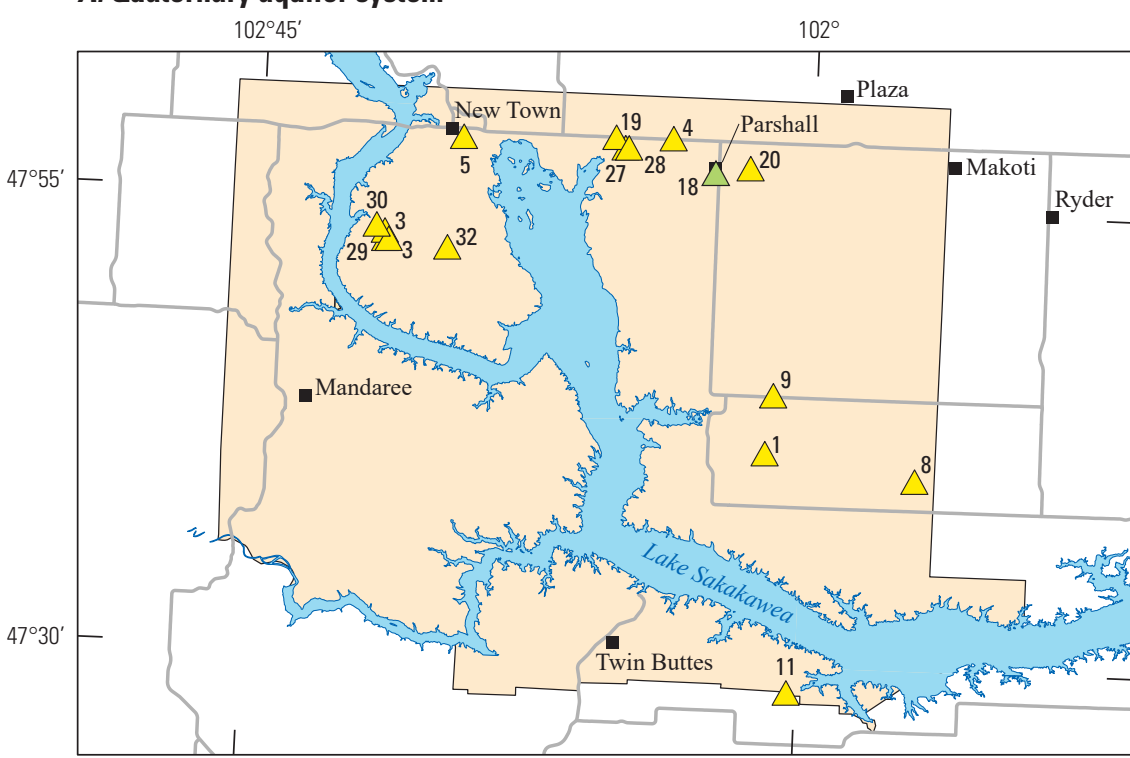

Base layers from North Dakota Geographic Information Systems (GIS) Hub Data Portal, 2018

Universal Transverse Mercator projection, zone $14 \mathrm{~N}$ North American Datum of 1983

\section{B. Lower Tertiary aquifer system}

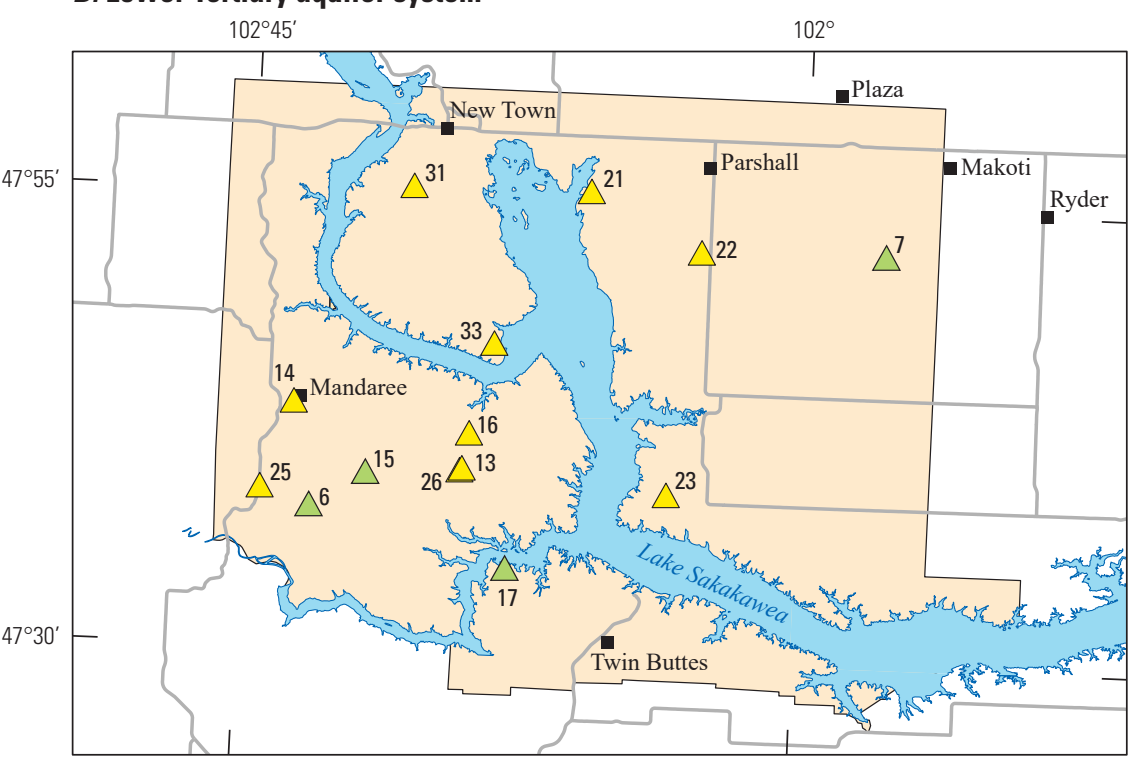

C. Upper Cretaceous aquifer system

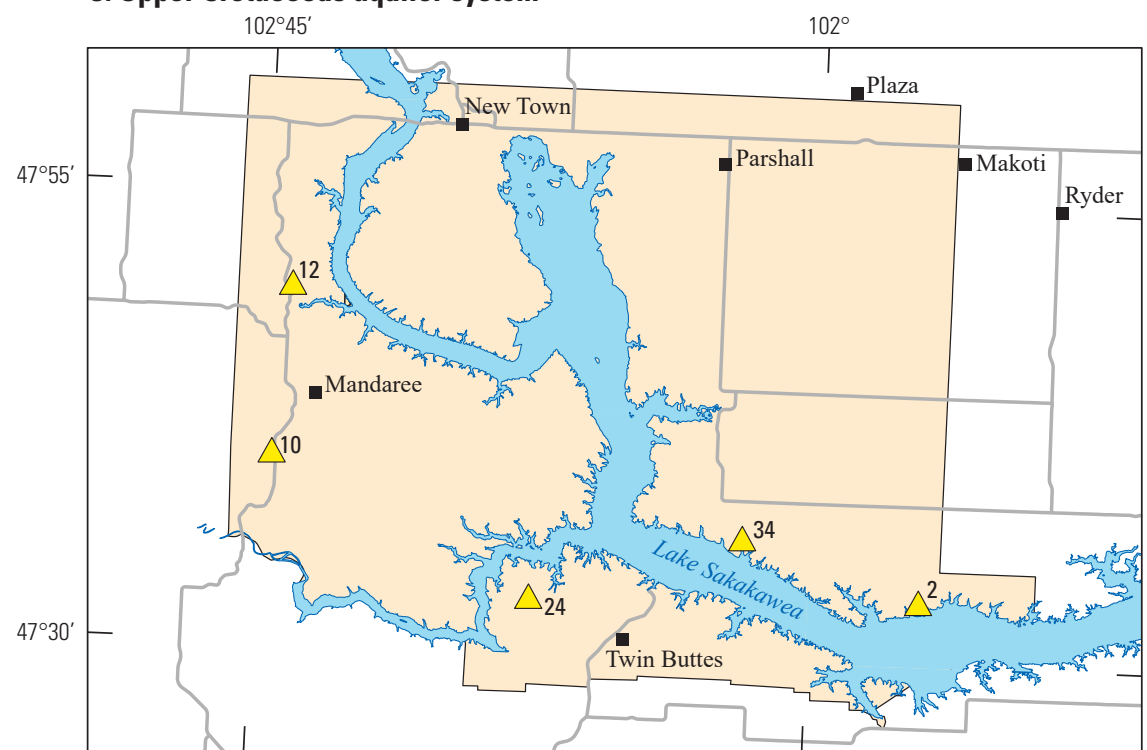

Figure 10. Spatial distribution of dissolved ammonia concentrations, in milligrams per liter, for groundwater wells on Fort Berthold Reservation, North Dakota, 2014-17.

$A$, Quaternary aquifer system; $B$, lower Tertiary aquifer system; and $C$, Upper Cretaceous aquifer system. 


\section{Summary}

The Fort Berthold Reservation (hereafter referred to as "reservation"), in west-central North Dakota, is home to the Three Affiliated Tribes (TAT). The primary water-resources concerns on the reservation are the different types of land uses from agricultural activities and the rapid development of oil and gas resources in western North Dakota. A primary goal of the TAT Environmental Department is to protect the water quality in streams, groundwater, and Lake Sakakawea from these water-resources issues on the reservation. As a result of these concerns, the TAT Environmental Department identified the need for long-term water-quality monitoring throughout the reservation to better understand the potential effects on surface-water and groundwater quality and to determine if water quality is changing with time. Therefore, a water-quality monitoring program was designed to address data gaps and provide consistent long-term data that can be used to identify potential effects on water quality. During 2014-17, the initial water-quality sampling efforts associated with this program were completed. The efforts provide a current (2019) characterization of water-quality conditions and assist in establishing a long-term water-quality monitoring program

The U.S. Geological Survey, in cooperation with the TAT, identified surface-water sites and groundwater wells that represent the water resources in major drainages and the most utilized aquifers on the reservation. Surface-water-quality samples were collected from six surface-water sites that were selected from previously established U.S. Geological Survey (USGS) streamgaging stations. Of the six sites selected, three are continuous-recording U.S. Geological Survey streamgaging stations currently (2019) operated on the reservation. These three streamgaging stations are Bear Den Creek near Mandaree, N. Dak.; East Fork Shell Creek near Parshall, N. Dak.; and Deepwater Creek at mouth near Raub, N. Dak. The other three surface-water sites are not continuously operated streamgaging stations.

Reconnaissance of potential groundwater wells for sampling began in May 2014, and 34 wells were selected for sampling. Initially, groundwater wells were selected by dividing the area of the reservation into 20 equal-area cells, and 1 well in each cell was randomly selected from the population of all wells available from multiple databases. Locating appropriate wells for sampling using the random selection approach presented several challenges in this area. With the development of the Fort Berthold Rural Water System and associated decrease in groundwater use, most of the domestic wells were disconnected and many of the monitoring wells on the reservation that were drilled prior to the 1990s were destroyed, abandoned, or no longer existed. Because of the challenges in locating appropriate wells using the random approach, additional wells were selected based on criteria that the wells could be physically located, the wells had construction information from a well driller's log, the samples could be collected without the well being affected by any type water treatment or a pressure tank, and the landowner had granted permission.
Six surface-water sites on streams and 34 groundwater wells were sampled on the reservation for 232 constituents that include major ions, nutrients, trace elements, and semivolatile and volatile organic compounds. Of the 232 constituents, 11 were selected for more detailed analyses and discussion based on their common association with agricultural and energy development land uses. These dissolved constituents are chloride, dissolved solids, sodium, sulfate, aluminum, arsenic, iron, manganese, ammonia, nitrate, and nitrite.

In surface-water samples, chloride concentrations were less than the U.S. Environmental Protection Agency (EPA) secondary drinking water regulation (SDWR) of 250 milligrams per liter $(\mathrm{mg} / \mathrm{L})$, and median chloride concentrations ranged from $4.3 \mathrm{mg} / \mathrm{L}$ at streamgaging station Squaw Creek above mouth near Mandaree, N. Dak. (USGS station number 06337480 ) to $24.9 \mathrm{mg} / \mathrm{L}$ at streamgaging station East Fork Shell Creek near Parshall, N. Dak. (USGS station number 06332523). Dissolved solids concentrations exceeded the EPA SDWR of $500 \mathrm{mg} / \mathrm{L}$ at all surface-water sites. The median dissolved solids concentrations tended to be greater in the western part of the reservation and lower in the eastern part of the reservation. The median dissolved solids concentrations ranged from $1,260 \mathrm{mg} / \mathrm{L}$ at streamgaging station Deepwater Creek at mouth near Raub, N. Dak. (USGS station number 06332770) to 3,370 $\mathrm{mg} / \mathrm{L}$ at the Squaw Creek streamgaging station. Sodium concentrations exceeded the EPA taste threshold of $30 \mathrm{mg} / \mathrm{L}$ at all surface-water sites. The median sodium concentrations ranged from $268 \mathrm{mg} / \mathrm{L}$ at the Deepwater Creek streamgaging station to $1,007 \mathrm{mg} / \mathrm{L}$ at the Squaw Creek streamgaing station. Sulfate concentrations exceeded the EPA SDWR of $250 \mathrm{mg} / \mathrm{L}$ at all surfacewater sites. The median sulfate concentrations ranged from $628 \mathrm{mg} / \mathrm{L}$ at the Deepwater Creek streamgaging station to $2,065 \mathrm{mg} / \mathrm{L}$ at the Squaw Creek streamgaging station.

Trace metals that were selected include dissolved aluminum, dissolved arsenic, dissolved iron, and dissolved manganese. Aluminum was detected in 17 samples collected during 2014-17 from the 6 surface-water sites. When detected, all concentrations exceeded the EPA SDWR of 50 micrograms per liter $(\mu \mathrm{g} / \mathrm{L})$. When detected, the median aluminum concentrations ranged from 116 to $216 \mu \mathrm{g} / \mathrm{L}$. Arsenic was detected in 58 samples collected during 2014-17 from the 6 surface-water sites at concentrations that were less than the EPA maximum contaminant level (MCL) of $10 \mathrm{mg} / \mathrm{L}$. When detected, the median arsenic concentrations ranged from 2 to $6.2 \mu \mathrm{g} / \mathrm{L}$. Iron was detected in 22 samples collected from the 6 surface-water sites at concentrations that were less than the EPA SDWR of $300 \mu \mathrm{g} / \mathrm{L}$. When detected, the median iron concentrations ranged from 138 to $250 \mu \mathrm{g} / \mathrm{L}$. Manganese was detected in 83 samples collected, and each of the 6 surface-water sites had samples with concentrations that exceeded the EPA SDWR of $50 \mu \mathrm{g} / \mathrm{L}$. When detected, the median detected manganese concentrations ranged from 20.9 to $122 \mu \mathrm{g} / \mathrm{L}$.

Nutrients that were selected include dissolved ammonia, dissolved nitrate, and dissolved nitrite. In surfacewater samples, ammonia was detected in seven samples at 
concentrations that were less than the EPA taste threshold of $30 \mathrm{mg} / \mathrm{L}$. When detected, the median ammonia concentrations ranged from 0.1 to $0.5 \mathrm{mg} / \mathrm{L}$. Dissolved nitrate was detected in nine samples at concentrations that were less than the EPA MCL of $10 \mathrm{mg} / \mathrm{L}$ and when detected, the median nitrate concentrations ranged from 0.016 to $0.268 \mathrm{mg} / \mathrm{L}$. Dissolved nitrite was detected in 14 samples at concentrations that were less than the EPA MCL of $1 \mathrm{mg} / \mathrm{L}$ and when detected, the median nitrite concentrations ranged from 0.007 to $0.012 \mathrm{mg} / \mathrm{L}$.

Groundwater-quality data were collected from 34 wells on the reservation during 2014, 2015, and 2017. The sampled wells completed in the Quaternary aquifer system (contained in Quaternary-age glacial and fluvial sediments in the reservation) consisted of 3 wells in the White Shield aquifer, 4 wells in the Sanish aquifer, 6 wells in the Shell Creek aquifer, 1 well in the New Town aquifer, and 1 well in the Tongue River aquifer. The sampled wells completed in lower Tertiary aquifer system consisted of 13 wells in the Sentinel Butte aquifer (contained in the Sentinel Butte Member of the Fort Union Formation) and 1 well in the Fort Union aquifer (contained in the Fort Union Formation). The sampled wells completed in the Upper Cretaceous aquifer system consisted of 5 wells in the Fox Hills aquifer (contained in the Fox Hills Sandstone). The 34 wells included domestic, stock, monitoring, and industrial wells that represent the most utilized aquifer units and had good spatial coverage on the reservation.

For groundwater samples, the major ions that were selected are dissolved chloride, dissolved solids, dissolved sodium, and dissolved sulfate. The only chloride concentration that exceeded the EPA SDWR of $250 \mathrm{mg} / \mathrm{L}$ was from a well completed in the Upper Cretaceous aquifer system. The median chloride concentrations were 5.1, 2.6, and $237 \mathrm{mg} / \mathrm{L}$ in the Quaternary, lower Tertiary and Upper Cretaceous aquifer systems, respectively. The Upper Cretaceous aquifer system had the highest chloride concentrations that ranged from 185 to $271 \mathrm{mg} / \mathrm{L}$. Dissolved solids concentrations exceeded the EPA SWDR of $500 \mathrm{mg} / \mathrm{L}$ in samples from 32 of 34 groundwater wells. The median dissolved solids concentrations were $1,710,1,459$, and $1,590 \mathrm{mg} / \mathrm{L}$ in the Quaternary, lower Tertiary, and Upper Cretaceous aquifer systems, respectively. The median dissolved solids concentrations were more than double the EPA SDWR of $500 \mathrm{mg} / \mathrm{L}$. The dissolved solids concentrations that exceeded the EPA benchmark of $500 \mathrm{mg} / \mathrm{L}$ were spatially distributed throughout the reservation and included all the major aquifer systems. Dissolved sodium concentrations exceeded the EPA taste threshold of $30 \mathrm{mg} / \mathrm{L}$ in samples from all groundwater wells. The median detected sodium concentrations were 513,281 , and $587 \mathrm{mg} / \mathrm{L}$ in the Quaternary, lower Tertiary, and Upper Cretaceous aquifer systems, respectively. The dissolved sodium concentrations that exceeded the EPA taste threshold of $30 \mathrm{mg} / \mathrm{L}$ were spatially distributed throughout the reservation and included all the major aquifer systems. Dissolved sulfate concentrations exceeded the EPA SDWR of $250 \mathrm{mg} / \mathrm{L}$ in 21 of 34 groundwater wells. When detected, the median dissolved sulfate concentrations were 568 and $302 \mathrm{mg} / \mathrm{L}$ in the Quaternary and lower Tertiary aquifer systems, respectively. Dissolved sulfate concentrations were reported as nondetects in the Upper Cretaceous aquifer system. The highest detected sulfate concentrations that exceeded the EPA SDWR of $250 \mathrm{mg} / \mathrm{L}$ were in the Quaternary and lower Tertiary aquifer systems. A groundwater well in the Quaternary aquifer system was sampled twice and had sulfate concentrations of 2,300 and $1,730 \mathrm{mg} / \mathrm{L}$ in 2014 and 2017, respectively.

For groundwater samples, trace metals that were selected are dissolved aluminum, dissolved arsenic, dissolved iron, and dissolved manganese. All dissolved aluminum concentrations were reported as less than $100 \mu \mathrm{g} / \mathrm{L}$, except for one sample collected from a well in the lower Tertiary aquifer system, with a concentration of $137 \mu \mathrm{g} / \mathrm{L}$. Dissolved arsenic concentrations exceeded the EPA MCL of $10 \mu \mathrm{g} / \mathrm{L}$ in samples from 7 of 34 groundwater wells. When detected, the median dissolved arsenic concentrations were 8.9 and $3.5 \mu \mathrm{g} / \mathrm{L}$ in the Quaternary and Upper Cretaceous aquifer systems, respectively. Dissolved arsenic concentrations were reported as nondetects in the lower Tertiary aquifer system. The seven groundwater wells that exceeded the EPA MCL of $10 \mu \mathrm{g} / \mathrm{L}$ generally were on the northern and eastern side of the reservation from monitoring wells in the Quaternary aquifer system. Iron concentrations exceeded the EPA SDWR of $300 \mu \mathrm{g} / \mathrm{L}$ in 17 of 34 groundwater wells. When detected, the median dissolved iron concentrations were 1,220 and $230 \mu \mathrm{g} / \mathrm{L}$ in the Quaternary and lower Tertiary aquifer systems, respectively. Dissolved iron concentrations were reported as nondetects in the Upper Cretaceous aquifer system. The dissolved iron concentrations that exceeded the EPA SDWR of $300 \mu \mathrm{g} / \mathrm{L}$ were from wells in the Quaternary and lower Tertiary aquifer systems. Dissolved manganese concentrations exceeded the EPA SDWR of $50 \mu \mathrm{g} / \mathrm{L}$ in 14 of 34 groundwater wells. When detected, the median dissolved manganese concentrations were $104,46.8$, and $3 \mu \mathrm{g} / \mathrm{L}$ in the Quaternary, lower Tertiary, and Upper Cretaceous aquifer systems, respectively. The dissolved manganese concentrations that exceeded the EPA SDWR of $50 \mu \mathrm{g} / \mathrm{L}$ were from wells in the Quaternary and lower Tertiary aquifer systems.

For groundwater samples, nutrients that were selected are dissolved ammonia, dissolved nitrate, and dissolved nitrite. None of the nutrient concentrations exceeded any waterquality standards. Dissolved ammonia was detected in 30 samples at concentrations that were less than the EPA taste threshold of $30 \mathrm{mg} / \mathrm{L}$. When detected, the median dissolved ammonia concentrations were $0.6,0.2$, and $0.6 \mathrm{mg} / \mathrm{L}$ in the Quaternary, lower Tertiary, and Upper Cretaceous aquifer systems, respectively. Dissolved ammonia concentrations were detected from wells in each of the aquifer systems. Nitrate was detected in only one sample, and nitrite was not detected in any samples. All dissolved nitrate and dissolved nitrite concentrations were less than the EPA MCL of 10 and $1 \mathrm{mg} / \mathrm{L}$, respectively. 


\section{References Cited}

Bureau of Reclamation, 2016, Draft finding of no significant impact and final supplemental environmental assessment for funding of design, relocation, construction, operation and maintenance of the Twin Buttes Water Treatment Plant, Fort Berthold Rural Water System, Fort Berthold Indian Reservation, North Dakota: U.S. Department of the Interior, Bureau of Reclamation, Dakotas Area Office [variously paged], accessed May 10, 2018, at https://www.usbr.gov/gp/ dkao/nepa/sea_draft_fonsi_twin_buttes_wtp.pdf.

Cates, S.W., and Macek-Rowland, K.M., 1998, Water resources of the Fort Berthold Indian Reservation, westcentral North Dakota: U.S. Geological Survey WaterResources Investigations Report 98-4098. [Also available at https://doi.org/10.3133/wri984098.]

Childress, C.J., Foreman, W.T., Connor, B.F., and Maloney, T.J., 1999, New reporting procedures based on long-term method detection levels and some considerations for interpretations of water-quality data provided by the U.S. Geological Survey National Water Quality Laboratory: U.S. Geological Survey Open-File Report 99-193, 19 p., https://doi.org/10.3133/ofr99193.

Cunningham, W.L., and Schalk, C.W., comps., 2011, Groundwater technical procedures of the U.S. Geological Survey: U.S. Geological Survey Techniques and Methods 1-A1, 151 p. [Also available at https://pubs.usgs.gov/tm/ 1a1/pdf/tm1-a1.pdf.]

Dalrymple, A., 2018a, Trucking company pays $\$ 950,000$ fine for oilfield waste dumping: Bismarck, N. Dak., The Bismarck Tribune, accessed January 19, 2018, at https://bismarcktribune.com/news/state-and-regional/ trucking-company-pays-fine-for-oilfield-waste-dumping/ article_90d58816-cc49-52c2-b879-a2564578cec1.html.

Dalrymple, A., 2018b, Fine ordered for 2014 Fort Berthold pipeline spill: Bismarck, N. Dak., The Bismarck Tribune, accessed February 2, 2018, at https://bismarcktribune.com/ news/fine-ordered-for-fort-berthold-pipeline-spill/article 4011e3fd-3df3-5715-b5ec-073c6071c137.html.

Davis, B.E., 2005, A guide to the proper selection and use of federally approved sediment and water-quality samplers: U.S. Geological Survey Open-File Report 2005-1087, 20 p. [Also available at https://doi.org/10.3133/ofr20051087.]

DeSimone, L.A., McMahon, P.B., and Rosen, M.R., 2014, The quality of our Nation's waters - Water quality in principal aquifers of the United States, 1991-2010: U.S. Geological Survey Circular 1360, 151 p. [Also available at https://doi.org/10.3133/cir1360.]
Dingman, R.J., Gordon, E.D., and Swenson, H.A., 1954, Geology and ground-water resources of the Fort Berthold Indian Reservation, North Dakota, with a section on the chemical quality of the ground water: U.S. Geological Survey Water-Supply Paper 1259, 115 p., 2 pls. [Also available at https://doi.org/10.3133/wsp1259.]

Fishman, M.J., and Friedman, L.C., 1989, Methods for determination of inorganic substances in water and fluvial sediments: U.S. Geological Survey Techniques of WaterResources Investigations $05-\mathrm{A} 1,545 \mathrm{p}$. [Also available at https://doi.org/10.3133/twri05A1.]

Franzen, D., 2019, Managing saline soils in North Dakota: Fargo, N. Dak., North Dakota State University Extension Service SF-1087 (revised September 2019), 12 p., accessed January 2, 2020, at https://www.ag.ndsu.edu/publications/ crops/managing-saline-soils-in-north-dakota.

Galloway, J.M., Vecchia, A.V., Vining, K.C., Densmore, B.K., and Lundgren, R.F., 2012, Evaluation of water-quality characteristics and sampling design for streams in North Dakota, 1970-2008: U.S. Geological Survey Scientific Investigations Report 2012-5216, 304 p. [Also available at https://doi.org/10.3133/sir20125216.]

Hem, J.D., 1985, Study and interpretation of the chemical characteristics of natural water (3d ed.): U.S. Geological Survey Water-Supply Paper 2254, 263 p. [Also available at https://doi.org/10.3133/wsp2254.]

Kennedy, V.C., Zellweger, G.W., and Jones, B.F., 1974, Filter pore-size effects on the analysis of $\mathrm{Al}, \mathrm{Fe}, \mathrm{Mn}$, and $\mathrm{Ti}$ in water: Water Resources Research, v. 10, no. 4, p. 785-790, https://doi.org/10.1029/WR010i004p00785.

Lamb, D., Miller, D.F., Robinson, N.F., and Gertler, A.W., 1987, The importance of liquid water concentration in the atmospheric oxidation of SO2: Atmospheric Environment, v. 21 , no. 11 , p. 2333-2344, https://doi.org/10.1016/00046981(87)90369-6.

Macek-Rowland, K.M., and Lent, R.M., 1996, Variations in land use and nonpoint-source contamination on the Fort Berthold Indian Reservation, west-central North Dakota, 1990-93: U.S. Geological Survey Water-Resources Investigations Report 96-4007, 33 p. [Also available at https://doi.org/10.3133/wri964007.]

Maloney, T.J., ed., 2005, Quality management system, U.S. Geological Survey National Water Quality Laboratory: U.S. Geological Survey Open-File Report 2005-1263, version 1.3 [variously paged]. [Also available at https://doi.org/ 10.3133/ofr20051263.]

Mandan, Hidatsa, and Arikara Nation, 2020, Mandan, Hidatsa, and Arikara Nation-Three Affiliated Tribes: Mandan, Hidatsa, and Arikara Nation web page, accessed February 14, 2020, at https://www.mhanation.com/. 
National Water Quality Monitoring Council, 2018, National Water Quality Monitoring Council-Water quality portal: accessed April 2, 2018, at https://www.waterqualitydata.us.

Norman, J.E., Toccalino, P.L., and Morman, S.A., 2018, Health-based screening levels for evaluating water-quality data ( 2 d ed.): U.S. Geological Survey web page, accessed July 24, 2018, at https://water.usgs.gov/nawqa/HBSL.

North Dakota Department of Environmental Quality, 2018, Spill Investigation Program: North Dakota Department of Environmental Quality web page, accessed June 11, 2018, at https://deq.nd.gov/wq/4_Spill_Investigations/ Reports.aspx.

North Dakota Geographic Information Systems (GIS) Hub Data Portal, 2018, GIS hub data portal: accessed October 28, 2019, at https://gishubdata.nd.gov/.

North Dakota Industrial Commission, 2017, North Dakota general statistics: accessed June 11, 2018, at https://www.dmr.nd.gov/oilgas/stats/statisticsvw.asp.

North Dakota State Water Commission, 2014a, Ground/surface water data: North Dakota State Water Commission web page, accessed May 1, 2019, at https://www.swc.nd.gov/ info_edu/map_data_resources/groundsurfacewater/.

North Dakota State Water Commission, 2014b, Well driller contractor logs: North Dakota State Water Commission web page, accessed May 1, 2019, at http:/www.swc.state.nd.us/ info_edu/map_data_resources/privatecontractors/.

Rantz, S.E., and others, 1982, Measurement and computation of streamflow_-Volume 2, computation of discharge: U.S. Geological Survey Water-Supply Paper 2175, p. 285-631. [Also available at https://doi.org/10.3133/wsp2175.]

Rosseland, B.O., Eldhuset, T.D., and Staurnes, M., 1990, Environmental effects of aluminum: Environmental Geochemistry and Health, v. 12, no. 1-2, p. 17-27. [Also available at https://doi.org/10.1007/BF01734045.]

Scott, J.C., 1990, Computerized stratified random siteselection approaches for design of a groundwater-quality sampling network: U.S. Geological Survey Water-Resources Investigations Report 90-4101, 109 p. [Also available at https://doi.org/10.3133/wri904101.]

Smith, R.A., and Alexander, R.B., 1986, Correlations between stream sulfate and regional SO2 emissions: Nature, v. 322, no. 6081, p. 722-724, https://doi.org/10.1038/322722a0.

Turnipseed, D.P., and Sauer, V.B., 2010, Discharge measurements at gaging stations: U.S. Geological Survey Techniques and Methods, book 3, chap. A8, 87 p. [Also available at https://doi.org/10.3133/tm3A8.]
U.S. Environmental Protection Agency, 1994, Water quality standards handbook (2d ed.): U.S. Environmental Protection Agency, Office of Water, EPA 823-B-94-005a, 202 p., accessed April 1, 2018, at https://www.epa.gov/ sites/production/files/2016-06/documents/wqs-handbook1994.pdf.

U.S. Environmental Protection Agency, 2012, Quality Management Plan: Denver, Colo., U.S. Environmental Protection Agency, Region 8, accessed February 27, 2020, at https://www.epa.gov/quality/region-8-qualitymanagement-plan.

U.S. Environmental Protection Agency, 2016, Hydraulic fracturing for oil and gas-Impacts from the hydraulic fracturing water cycle on drinking water resources in the United States (final report): Washington, D.C., U.S. Environmental Protection Agency Final Report 600/R-16/236F, accessed April 1, 2018, at https://www.epa.gov/hfstudy.

U.S. Environmental Protection Agency, 2018, 2018 Edition of the drinking water standards and health advisories: Washington, D.C., U.S. Environmental Protection Agency, Office of Water, EPA 822-F-18-001, 12 p., accessed April 1, 2018, at https:/www.epa.gov/sites/production/files/ 2018-03/documents/dwtable2018.pdf.

U.S. Geological Survey, variously dated, National field manual for the collection of water-quality data: U.S. Geological Survey Techniques of Water-Resources Investigations, book 9, chaps. A1-A10 [variously paged]. [Also available at https://pubs.water.usgs.gov/twri9A.]

U.S. Geological Survey, 2017, USGS water data for the Nation: U.S. Geological Survey National Water Information System (NWIS) database, accessed February 1, 2017, at https://doi.org/10.5066/F7P55KJN.

Wald, J.D., and Cates, S.W., 1995, Water-resources data for the Fort Berthold Indian Reservation, west-central North Dakota: U.S. Geological Survey Open-File Report 95-304, 272 p., 1 pl. [Also available at https://doi.org/10.3133/ ofr95304.]

Warner, K.L., and Ayotte, J.D., 2014, The quality of our Nation's waters - Water quality in the glacial aquifer system, northern United States, 1993-2009: U.S. Geological Survey Circular 1352, 116 p. [Also available at https://doi. org/10.3133/cir1352.] 


\section{Appendix 1. Quality-Assurance Data and Summary Statistics for Water-Quality Constituents in Surface Water and Groundwater}

This appendix contains a link listing of the qualityassurance data and summary statistics for water-quality constituents in surface water and groundwater for samples collected for the study and historical water-quality data for surface-water sites and are presented in the Microsoft Excel file available at https://dx.doi.org/10.3133/sir20205020. The Microsoft Excel file contains the following five tables:

Table 1.1. Quality-assurance data collected for selected constituents on Forth Berthold Reservation, North Dakota, 2014-17.

Table 1.2. Quality-assurance data collected for additional constituents on Fort Berthold Reservation, North Dakota, 2014-17.

Table 1.3. Summary statistics for water-quality constituents analyzed but not selected for additional discussion in surface water on Fort Berthold Reservation, 2014-17.

Table 1.4. Summary statistics for historical water-quality constituents at surface-water sites on Fort Berthold Reservation, August 1966 to April 2014.

Table 1.5. Summary statistics for water-quality constituents analyzed but not selected for additional discussion in groundwater on Fort Berthold Reservation, 2014-17. 


\section{Appendix 2. Summary Statistics for Historical Water-Quality Constituents in Major Aquifers on Fort Berthold Reservation, North Dakota}

This appendix contains a link listing of the historical water-quality constituents in major aquifers on Fort Berthold Reservation, North Dakota, and are presented in the Microsoft
Excel file available at https://dx.doi.org/10.3133/sir20205020.

The Microsoft Excel file contains the following table:

Table 2.1. Summary statistics for historical water-quality constituents in major aquifers on Fort Berthold Reservation, North Dakota. 
For more information about this publication, contact:

Director, USGS Dakota Water Science Center

821 East Interstate Avenue, Bismarck, ND 58503

1608 Mountain View Road, Rapid City, SD 57702

605-394-3200

For additional information, visit: https://www.usgs.gov/centers/ dakota-water

Publishing support provided by the

Rolla Publishing Service Center 



\section{एक्ष}

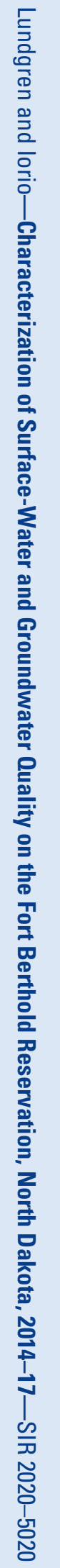

